2020-05

\title{
Multidirectional conditional convergence in European banking
}

\section{Tziogkidis, Panagiotis}

http://hdl.handle.net/10026.1/15496

10.1016/j.jebo.2020.03.013

Journal of Economic Behavior \& Organization

Elsevier BV

All content in PEARL is protected by copyright law. Author manuscripts are made available in accordance with publisher policies. Please cite only the published version using the details provided on the item record or document. In the absence of an open licence (e.g. Creative Commons), permissions for further reuse of content should be sought from the publisher or author. 
This paper has been accepted for publication in the Journal of Economic Behavior and Organization.

The final publication is available at Elsevier via: https://doi.org/10.1016/j.jebo.2020.03.013

Please cite this article as: P. Tziogkidis, D. Philippas, and M.G. Tsionas, 2020.

Multidirectional conditional convergence in European banking, Journal of Economic

Behavior and Organization 173, 88-106. https://doi.org/10.1016/j.ejor.2020.02.023

Copyright Notice: This work is licensed under a Creative Commons Attribution-

NonCommercial-NoDerivatives 4.0 International License. For more information please follow the hyperlink and click on the icon below. 


\section{Highlights}

- We examine the productivity and convergence behaviour of SSM-supervised banks

- A novel approach that tests for convergence in multiple dimensions is proposed

- We introduce the concept of convergence in productivity and technology

- We find strong evidence of absolute convergence and therefore integration

- Minimum liquidity and capital adequacy requirements enabled absolute convergence 


\title{
Multidirectional conditional convergence in European banking
}

\author{
Panagiotis Tziogkidis ${ }^{\mathrm{a}}$, Dionisis Philippas ${ }^{\mathrm{b}}$ and Mike G. Tsionas ${ }^{\mathrm{c}}$ \\ ${ }^{a}$ University of Plymouth, Cookworthy Building, Drake Circus, PL4 8AA, Plymouth, UK, \\ panagiotis.tziogkidis@plymouth.ac.uk. \\ ${ }^{\mathrm{b}}$ ESSCA School of Management, 55 Quai Alphonse Le Gallo, 92513, Boulogne, Paris, France, \\ dionisis.philippas@essca.fr. \\ c Lancaster University Management School, LA1 4YX, Lancaster, UK, m.tsionas@lancaster.ac.uk.
}

\begin{abstract}
The paper examines the behavioural patterns arising from the analysis of productivity and convergence in European banking, using a sample of commercial banks regulated by the Single Supervisory Mechanism, during 2011 to 2017. Productivity change and its decompositions is measured for each input and output dimension separately, using a variant of the multidirectional productivity analysis framework. We introduce a novel approach for testing for $\beta$-convergence in productivity, efficiency and technology, as well as in each dimension considered. We find strong evidence of absolute convergence during the period of study, suggesting that bank operations move towards a common frontier rather than local equilibria. Prior to the creation of the Single Supervisory Mechanism in 2013, conditional convergence is confirmed in many instances with respect to liquidity and capital adequacy, although few cases remain significant in the subsequent period. We conclude that regulatory controls have facilitated integration, though there are important implications arising that policymakers need to consider when designing policies.
\end{abstract}

Keywords: multi-directional productivity change, beta convergence, European banking, regulation. JEL classifications: C61, G21, G28, L25. 


\section{Introduction}

The integration of the European banking sector has been a long-standing goal for European authorities, with the First Banking Directive of 1977 marking the first significant attempt. Differences in the institutional framework of European banking have been an impeding factor, though they have gradually diminished. Despite the continuous progress over the last four decades, with the most notable recent example being the creation of the Single Supervisory Mechanism (SSM), significant barriers to integration still exist, especially in retail and small business banking (Goddard et al., 2015). Additional challenges are imposed due to the substantial differences in productivity and technology across European banking sectors and within each country (Bos and Schmiedel, 2007; Kontolaimou et al., 2012). Convergence in productivity, which is a cited antecedent for integration, has been mainly proxied by measures of convergence in efficiency and productivity change, rather than being estimated directly. Aggregate measures of efficiency and total factor productivity (TFP) are mainly used which cannot account for uneven technical change; the fact that productivity can grow at different rates or even direction with respect to each input and output that defines the banking technology. This paper proposes a novel approach that allows to test for convergence in each dimension of productivity and its components, introducing in this context the notion of convergence in technology.

In the economic literature, $\beta$-convergence examines the hypothesis that low-income counties are expected to grow faster than richer ones, catching up with the higher per capita GDP levels of the latter (Baumol, 1986; Barro and Sala-i-Martin, 1992). In the banking literature, no formal definition has been offered, though it could be argued that, under the neoclassical framework, less productive firms (banks) are expected to intensify their efforts in catching up with more productive ones to avoid being driven out of competition, thus exhibiting a higher pace of productivity growth. This has direct implications for the two frequently used components of productivity change: efficiency change and technical change. That is, if banks are assumed to exhibit similar levels of productivity in the long run, they should also do so for efficiency and technology. While efficiency convergence has been well-examined in the literature, the notion of convergence in technology has not been yet considered. We define convergence 
in technology as the extent to which banks have access to and make use of the same technological and financial innovations, so that they can all attain the same frontier that reflects the level of technology.

The empirical literature on convergence in European banking offers results that vary with the period examined or the approach followed, while it reveals gaps that we address in this paper. ${ }^{1}$ First, to our knowledge, no study has previously examined for convergence in productivity and its components, namely convergence in efficiency and technology, defined above. The yet few studies test for convergence in the growth rate of productivity and its decompositions (Degl'Innocenti et al., 2017; Fujii et al., 2018), suggesting that this is a promising area for further development. Second, convergence analysis is based on aggregate measures of efficiency and productivity change, rather than being evaluated with respect to each input and output, separately. The closest approach is offered by Fujii et al. (2018) who test for convergence in the contribution of each individual input to bank inefficiency. ${ }^{2}$ Finally, conditional convergence has not received adequate attention in the banking literature (Casu et al., 2016). This is particularly important since certain banks may converge to different equilibria influenced by country characteristics, institutional differences, regulation or other factors associated with the environment in which banks operate.

This paper proposes a novel approach that estimates conditional $\beta$-convergence in productivity, efficiency and technology for each input and output dimension considered, thus addressing the identified gaps. We apply our framework on the commercial banks supervised by the SSM during the period from 2011 to 2017, which includes challenges for integration, such as the European sovereign debt crisis, but also opportunities, such as the creation of the SSM. To evaluate productivity in each dimension and decomposition, we build on the multidirectional productivity change (MPC) model of

\footnotetext{
${ }^{1}$ Previous studies on European banking have tested for convergence in cost efficiency (Mamatzakis et al., 2008; Weil, 2009) and technical efficiency (Casu and Girardone, 2010; Matousek et al., 2015), conditional convergence in technical efficiency (Casu et al., 2016), as well as convergence in productivity change and its decompositions (Degl'Innocenti et al., 2017; Fujii et al., 2018).

${ }^{2}$ Fujii et al. (2018) use a weighted Russel directional distance model which includes priority weights imposed by the user, to optimise the contribution of each individual input to the aggregate inefficiency of each bank, under the objective of minimising that aggregate level of inefficiency. That is, the individual input inefficiencies, by definition, sum up to the total inefficiency for each bank.
} 
Asmild et al. (2016). We then introduce a novel approach for testing for $\beta$-convergence in productivity, efficiency and technology. Finally, to account for conditional convergence, we consider the role of capital adequacy and liquidity, which are important dimensions of regulatory oversight, also emphasized in the Basel III framework. The underlying logic is that, given the unifying role of the SSM in supervising and implementing a common regulatory framework for all banks, the supervised entities should be able to converge towards a global equilibrium, or frontier, (absolute convergence) rather than local ones that depend on exogenous factors (conditional convergence).

To anticipate empirical findings, we find substantial asymmetries in the behaviour of productivity, efficiency and frontier catch-up of SSM-supervised banks. The creation of the SSM in 2013, has marked an increase in technical efficiency across all input and output dimensions considered, accompanied with a deterioration in the level of technology, though. We attribute this to the stricter supervision and additional controls from the European Central Bank (ECB), especially after 2013. Considering the full period of study, we find strong evidence of absolute convergence but no evidence of conditional convergence, indicating that SSM commercial banks converge towards a common frontier across dimensions. We attribute this to the role of the SSM and the introduction of additional controls after 2013, given that, before that time, we find conditional convergence with respect to the two regulatory variables considered, while afterwards absolute convergence is stronger. Our findings carry important implications as we show that, although imposing additional restrictions may be conducive to integration, it can slow down financial and technological innovation.

The remainder of the paper is structured as follows. Section 2 presents the data and discusses the choice of variables. Section 3 introduces our methodological approach. Section 4 discusses the empirical findings and the policy implications arising. Finally, section 5 concludes the paper.

\section{Data}

We use data from the financial statements of the European commercial banks supervised directly by the SSM. The list of supervised 'significant institutions' is updated annually, according to predetermined 
criteria linked to the importance of a bank for the host economy. ${ }^{3}$ The fact that the SSM-supervised commercial banks are of systemic importance and face a common regulatory framework, makes them suitable for a European analysis of productivity, due to the homogeneity of operations they are expected to have, compared to other non-SSM financial institutions.

Our dataset spans from 2011 to 2017, which is a period of significance for the European banking industry. To begin with, the European sovereign debt crisis was set out in mid-2010, sparking fears for contagion to the financial sector. Many financial institutions faced challenges, reflected in limited profitability and liquidity, while the impact of the crisis on the real economy was reflected in an increasing trend in non-performing loans and declining investment opportunities. At the DirectorateGeneral for Finance meeting of 2011 in Cyprus, the intention for the creation of the SSM was announced, suggesting the beginning of a period of policy-induced regulatory and operational convergence. The creation of the SSM in 2013 marks a new period of stricter supervision and tighter controls by the ECB. The implementation of Basel III, the liquidity requirements specified in the minimum liquidity coverage ratio, as well as the capital requirements linked with stress testing, are some of the examples of increased regulation and supervision that followed the creation of the SSM. Taking also into account the liquidity injections through the quantitative easing programme of the ECB, suggested that financial institutions would need to reconsider their strategies.

To measure efficiency and productivity change we define the input-output system as an extension of the intermediation approach (Sealey and Lindley, 1977), which views financial institutions as intermediaries that use capital and labour to convert liabilities into assets. Under this approach, banks use capital (Fixed Assets), labour (Staff Expenses) and deposits (Customer Deposits) to produce loans

\footnotetext{
${ }^{3}$ The criteria for significance for a financial institution that the ECB has set out include (i) total assets in excess of $€ 30$ billion, (ii) total assets in excess of $€ 30$ billion but with more than $20 \%$ ratio of cross-border assets to liabilities in more than one EU countries, (iii) it has requested or received funding from the European Stability Mechanism (ESM) or the European Financial Stability Facility (EFSF), or (iv) it is of economic importance to the country that it is based in or for the whole EU economy. It is also noted that the European Financial Stability Facility (EFSF) was created as a temporary crisis resolution mechanism by the Euro area Member States in June 2010. The assistance that EFSF provided was financed by bonds and other debt instruments issued by the organisation. The role of the EFSF is now performed by the ESM.
} 
(Net Loans) and other income-generating securities (Other Earning Assets). To avoid imposing restrictive assumptions on the nature of deposits as inputs or outputs, we treat them as non-discretionary inputs as in Asmild and Matthews (2012). ${ }^{4}$ The logic is that banks desire to maintain a certain level of deposits for their operations. However, if they are not income-generating, banks incur transaction and overhead costs for their management (Berger and Humphrey, 1992). Therefore, instead of optimising the behaviour of banks vis-à-vis minimising or maximising deposits, we only involve this variable in the construction of the feasible set. Finally, we treat Non-Performing Loans (NPLs) as an undesirable output, effectively modelled as an input (Assaf et al., 2013; Matousek et al., 2015; Fukuyama and Matousek, 2017). ${ }^{5}$ While the aggregate level of NPLs largely depends on the state of the economy, they can vary from bank to bank, influenced by the degree of risk that each financial institution is willing to undertake. The greater the degree of risk aversion, the greater the effort of a bank to minimise NPLs, by setting stricter criteria when extending credit, which further justifies the inclusion of NPLs as a nondesirable output in our model.

To examine conditional convergence, we also include the Liquid Assets Ratio (liquid to total assets ratio, or LAR), as well as the Capital Adequacy Ratio (CAR). Higher values for LAR suggest that a bank can effectively deal with an unexpected shock that would require using their liquid assets. At the same time, it indicates that the bank has more resources available to convert into income-generating assets. Therefore, the greater the liquidity in the market, the greater the potential for productivity growth in the banking sector. Liquidity gained particular significance after the implementation of minimum liquidity requirements by the ECB in 2014.

The CAR is a regulatory ratio that monitors the ability of a bank to absorb losses stemming from exposure to risk, using own funds. A high CAR could be interpreted as a sign of stability and of good

\footnotetext{
${ }^{4}$ The theoretical background on the input versus output debate for deposits is provided in Berger and Humphrey (1992). A detailed account on the controversy concerning the use of deposits as an input or output in one-stage models is provided in Fethi and Pasiouras (2010), while for an in-depth analysis of the "deposits dilemma" and the approaches followed additionally in in one-stage and two-stage models, the interested reader can consult Holod and Lewis (2011).

${ }^{5}$ Assaf et al. (2013) also provide a theoretical account on this issue and show that failing to account for NPLs can distort the efficiency and productivity results significantly.
} 
quality of assets that a bank maintains in its portfolio. Moreover, it could suggest that the bank is riskaverse, or that it is tightly supervised and unable to freely use its resources. Tighter regulations would mean that banks have fewer resources available to work with, and therefore their production possibilities would be reduced (Tziogkidis et al., 2018).

The average values for the inputs, outputs and the two regulatory ratios are presented in Table 1 below, in nominal terms. We observe an increase in both liquidity and capital adequacy after 2013, suggesting that the change in the liquidity and capital requirements, as well as the tighter supervision, all had an impact on bank operations. We also find that up to 2013, average Net Customer Loans were higher than Customer Deposits and moving at a declining trend, while after 2013, deposits exceeded on average bank loans. Moreover, Other Earning Assets have substantially declined after 2014, indicating a potential reconsideration of banks' portfolios in view of updated regulatory requirements. Finally, we observe that capital and staff-related costs appear stable, while the proportion of NPLs in relation to Net Customer Loans seems to be improving, indicating that banks have become more risk-averse.

Table 1. Averages of inputs, outputs and exogenous variables

\begin{tabular}{ccccccccc}
\hline Year & $\begin{array}{c}\text { Fixed } \\
\text { Assets }\end{array}$ & $\begin{array}{c}\text { Staff } \\
\text { Expenses }\end{array}$ & $\begin{array}{c}\text { Customer } \\
\text { Deposits }\end{array}$ & NPLs & $\begin{array}{c}\text { Net } \\
\text { Customer } \\
\text { Loans }\end{array}$ & $\begin{array}{c}\text { Other } \\
\text { Earning } \\
\text { Assets }\end{array}$ & $\begin{array}{c}\text { Liquid } \\
\text { Assets } \\
\text { Ratio }\end{array}$ & $\begin{array}{c}\text { Capital } \\
\text { Ad. Ratio }\end{array}$ \\
\hline 2011 & $1,727.7$ & $1,782.4$ & $88,363.2$ & $7,857.5$ & $111,116.1$ & $114,898.4$ & 17.5 & 13.4 \\
2012 & $1,679.5$ & $1,730.0$ & $89,109.1$ & $9,046.0$ & $105,762.4$ & $109,732.8$ & 17.7 & 14.4 \\
2013 & $1,621.2$ & $1,643.4$ & $89,494.1$ & $10,188.3$ & $98,771.7$ & $96,125.5$ & 17.8 & 15.9 \\
2014 & $1,696.0$ & $1,632.6$ & $91,824.7$ & $10,057.0$ & $99,243.8$ & $105,073.9$ & 17.5 & 17.2 \\
2015 & $1,820.8$ & $1,704.1$ & $101,331.3$ & $9,617.5$ & $106,143.5$ & $97,642.6$ & 18.0 & 18.7 \\
2016 & $1,866.3$ & $1,703.1$ & $101,511.1$ & $9,087.9$ & $104,079.3$ & $92,069.9$ & 18.3 & 18.3 \\
2017 & $1,986.5$ & $1,769.7$ & $107,633.5$ & $7,818.1$ & $108,652.3$ & $83,805.1$ & 19.4 & 18.8 \\
\hline Total & $1,770.8$ & $1,708.3$ & $95,637.5$ & $9,114.1$ & $104,748.8$ & $99,843.0$ & 18.0 & 16.7 \\
\hline \hline
\end{tabular}

Notes: The table presents the average values for the inputs (columns 2-4), the undesirable output that is treated as an input (column 5), the outputs (columns 6-7) and liquidity and capital adequacy ratios (columns 8-9) for each year of the study period. The input-output variables are in million euros, while the ratios are in percentages.

\section{Methodological framework}

\subsection{Theoretical background}

In the context of production economics, the efficiency of a decision-making unit (DMU) is measured 
against a frontier that characterises the level of technology. The DMUs operating on the frontier are efficient, while along with the input-output combinations that it envelopes, they define the feasible set. Formally, assuming a set of $n$ DMUs, $p$ inputs and $q$ outputs, the feasible set is defined as:

$$
\Psi=\left\{(x, y) \in \mathbb{R}_{+}^{p+q} \mid x \text { can produce } y\right\}
$$

Considering the Farrell-Debreu definition of efficiency (Debreu, 1951; Farrell, 1957) and under the assumption of input (output) orientation, an inefficient DMU would need to equiproportionately decrease (increase) all its inputs (outputs), while maintaining its outputs (inputs) fixed until it attains the frontier. While in certain settings this may be a reasonable assumption, it can prove quite limiting within the banking context. Financial institutions, even when considering commercial banks only, can have substantially different operations, which can be reflected in different input-output proportions. For example, some banks may focus mainly on traditional banking operations whereas others may engage more on investment activities. Similarly, risk-averse banks may have stricter credit controls and maintain a lower level of non-performing loans (NPLs) compared to their peers, while similar arguments can be made about the technological and financial innovations used or the capital versus labour intensity of bank operations. Directional measures of efficiency are more suitable in this context, allowing for non-radial, non-oriented improvements, across all input-output dimensions (Chambers et al., 1998). Therefore, it is possible to analyse not just the levels, but also the patterns of efficiency of financial institutions.

The direction of improvement for each input and output dimension is determined through the directional matrix $g=\left(g_{x}, g_{y}\right) \in \mathbb{R}^{p+q}$, where $g_{x}=\left(g_{x_{1}}, \ldots g_{x_{p}}\right)$ and $g_{y}=\left(g_{y_{1}}, \ldots g_{y_{q}}\right)$. The directional distance function can then be defined as:

$$
\vec{D}\left(x, y ; g_{x}, g_{y}\right)=\sup \left\{\beta \in \mathbb{R}^{+} \mid\left(x-\beta g_{x}, y+\beta g_{y}\right) \in \Psi\right\}
$$

where $\beta$ is a multiplicative factor applied on the specified directional vectors, which together determine the required improvements in inputs $\left(\beta g_{x}\right)$ and outputs $\left(\beta g_{y}\right)$ that make a DMU efficient.

The directional matrix $g$ can be common for all inputs and outputs (Färe et al., 2005), it can be imposed by the user according to policy objectives, it can be determined through an optimised objective function (Atkinson and Tsionas, 2016) or it can be chosen with respect to the maximum potential 
improvements in each input and output dimension, via multidirectional efficiency analysis (MEA) (Asmild et al., 2003; Bogetoft and Hougaard, 1999). In this paper, we define the directional vectors using MEA.

To measure productivity change, the Malmquist index is the most commonly used approach, which effectively assesses the operations of a DMU in two different periods against a fixed period's reference technology (frontier). Let us denote the two time periods with $t$ and $t+1$, where $t+1$, without loss of generality and for ease of exposition, refers to any point in time after $t$. The Malmquist index with reference technology at time $t$ is defined as:

$$
M^{t}=\frac{\vec{D}^{t}\left(x_{t+1}, y_{t+1} ; g\right)}{\vec{D}^{t}\left(x_{t}, y_{t} ; g\right)}
$$

where $\vec{D}^{t}\left(x_{t}, y_{t} ; g\right)$ is the contemporaneous distance function of DMU $\left(x_{t}, y_{t}\right), \vec{D}^{t}\left(x_{t+1}, y_{t+1} ; g\right)$ is the cross-period distance function of DMU $\left(x_{t+1}, y_{t+1}\right)$ while $g$ is the directional matrix to which we have attached no time subscript for ease of exposition. The exact definition of $g$ in both periods depends on the approach used, discussed in detail in the next subsection. Similarly, using as a reference period $t+1$, the Malmquist index is:

$$
M^{t+1}=\frac{\vec{D}^{t+1}\left(x_{t+1}, y_{t+1} ; g\right)}{\vec{D}^{t+1}\left(x_{t}, y_{t} ; g\right)}
$$

where $\vec{D}^{t+1}\left(x_{t+1}, y_{t+1} ; g\right)$ and $\vec{D}^{t+1}\left(x_{t}, y_{t} ; g\right)$ are the contemporaneous and cross-period distance functions, respectively. To avoid arbitrarily choosing between the two reference periods, the Malmquist index is usually defined as the geometric mean of (3) and (4):

$$
M\left(x_{t}, y_{t}, x_{t+1}, y_{t+1}\right)=\left[\frac{\vec{D}^{t}\left(x_{t+1}, y_{t+1} ; g\right)}{\vec{D}^{t}\left(x_{t}, y_{t} ; g\right)} \cdot \frac{\vec{D}^{t+1}\left(x_{t+1}, y_{t+1} ; g\right)}{\vec{D}^{t+1}\left(x_{t}, y_{t} ; g\right)}\right]^{\frac{1}{2}}
$$

The index can be decomposed into efficiency change (EC) and technical change (TC), or frontier shift, as follows:

$$
M\left(x_{t}, y_{t}, x_{t+1}, y_{t+1}\right)=\frac{\vec{D}^{t+1}\left(x_{t+1}, y_{t+1} ; g\right)}{\vec{D}^{t}\left(x_{t}, y_{t} ; g\right)} \cdot\left[\frac{\vec{D}^{t}\left(x_{t+1}, y_{t+1} ; g\right)}{\vec{D}^{t+1}\left(x_{t+1}, y_{t+1} ; g\right)} \cdot \frac{\vec{D}^{t}\left(x_{t}, y_{t} ; g\right)}{\vec{D}^{t+1}\left(x_{t}, y_{t} ; g\right)}\right]^{\frac{1}{2}}
$$

where: 


$$
E C=\frac{\vec{D}^{t+1}\left(x_{t+1}, y_{t+1} ; g\right)}{\vec{D}^{t}\left(x_{t}, y_{t} ; g\right)}
$$

and:

$$
T C=\left[\frac{\vec{D}^{t}\left(x_{t}, y_{t} ; g\right)}{\vec{D}^{t+1}\left(x_{t}, y_{t} ; g\right)} \cdot \frac{\vec{D}^{t}\left(x_{t+1}, y_{t+1} ; g\right)}{\vec{D}^{t+1}\left(x_{t+1}, y_{t+1} ; g\right)}\right]^{\frac{1}{2}}
$$

Technical change captures the frontier shift between two periods and is defined as the distance of a reference DMU from the two frontiers. As with the Malmquist index, TC is also determined as a geometric mean, this time between DMU operations at $t$ and $t+1$. Denoting with $T C_{t}$ and $T C_{t+1}$ the technical change with reference to DMU $\left(x_{t}, y_{t}\right)$ and $\left(x_{t+1}, y_{t+1}\right)$, respectively, we have:

$$
T C_{t}=\frac{\vec{D}^{t}\left(x_{t}, y_{t} ; g\right)}{\vec{D}^{t+1}\left(x_{t}, y_{t} ; g\right)}
$$

and

$$
T C_{t+1}=\frac{\vec{D}^{t}\left(x_{t+1}, y_{t+1} ; g\right)}{\vec{D}^{t+1}\left(x_{t+1}, y_{t+1} ; g\right)}
$$

so that $T C=\left[T C_{t} \cdot T C_{t+1}\right]^{\frac{1}{2}}$. We will use this disaggregation later to define convergence in technology.

\subsection{Multi-directional productivity change}

We measure productivity change and its decompositions using the multi-directional productivity change (MPC) model (Asmild et al., 2016), which has not yet received much attention in the literature. It builds on the multidirectional efficiency analysis (MEA) (Bogetoft and Hougaard, 1999; Asmild et al., 2003) and it has the advantage of allowing for the measurement of productivity change and its components, separately for each input and output dimension. Thus, using the MEA-Malmquist index it is possible not only to measure productivity change and its decompositions, but also to examine the patterns arising from productivity growth in each dimension.

Similar to Asmild and Matthews (2012), we use a non-oriented model, under the assumption that SSM-supervised banks can exert control over both inputs and outputs, given their significance in the European financial markets. Moreover, since the commercial banks in our sample are systemically important and regulated under a common framework by the SSM, the assumption of constant returns to 
scale (CRS) is reasonable. Given its consistency with absolute convergence in productivity, the CRS assumption is also in line with setting common long-run improvement targets for each bank, irrespective of their scale of operations.

Finally, it is well-established in the literature that there can be infeasibilities in estimating productivity change using directional distance functions in general (Briec and Kerstens, 2009), or MEA in particular (Asmild et al., 2016). The issue arises from the calculation of cross-period distance functions. That is, one of the two components of technical change in (9) and (10) cannot be calculated in some cases. To partly deal with this issue, we proxy technical change for the problematic cases with whichever base-period definition is free from infeasibilities, instead of their geometric mean.

Consider a reference DMU ' $o$ ' and let $\tau=\{t, t+1\}$ and $\tau^{\prime}$ be the complement of $\tau$. Moreover, to make our notation appear less cluttered, we will use in this subsection appropriate superscripts on input and output variables to denote the period in which the reference DMU operates. To estimate the directional distance functions, we use MEA, which follows a two-step process. The first step identifies the ideal reference point $\left(\boldsymbol{x}_{o}^{*, \tau}, \boldsymbol{y}_{o}^{*, \tau}\right)=\left(x_{o, 1}^{*, \tau}, \ldots x_{o, p}^{*, \tau}, y_{o, 1}^{*, \tau}, \ldots y_{o, q}^{*, \tau}\right)$, which determines the direction of the maximum potential improvements for $D M U_{o}$ for each input $j=1, \ldots p$ and output $r=1, \ldots q$, separately. To obtain the contemporaneous distance functions, the ideal reference point is determined against the respective period's reference set, so that $g_{\tau}\left(x_{j}^{\tau}\right)=x_{o, j}^{\tau}-x_{o, j}^{*, \tau}$ and $g_{\tau}\left(y_{r}^{\tau}\right)=y_{o, r}^{*, \tau}-y_{o, r}^{\tau}$. For the cross-period distance functions, we slightly divert from Asmild et al. (2016) in that the ideal reference point is also determined against the reference technology, so that $g_{\tau}\left(x_{j}^{\tau^{\prime}}\right)=x_{o, j}^{\tau^{\prime}}-x_{o, j}^{*, \tau}$ and $g_{\tau}\left(y_{r}^{\tau^{\prime}}\right)=y_{o, r}^{*, \tau}-y_{o, r}^{\tau^{\prime}}$. That is, for reference technology $\tau$, we use the same ideal reference point $\left(\boldsymbol{x}_{o}^{*, \tau}, \boldsymbol{y}_{o}^{*, \tau}\right)$ for both the contemporaneous and cross-period distance functions. The underlying assumption is that banks benchmark their operations against a fixed point of reference in both periods. Intuitively, we assume that a bank sets an optimal direction for improvement in the reference period (towards the respective ideal reference point) and evaluates its performance in the other period with 
respect to the same target. ${ }^{6}$

Given that it is the same for both types of distance functions, we only need to consider the following linear program to determine the input coordinates of the ideal reference point:

$$
\begin{aligned}
& \min _{\lambda, x_{o, j}^{*, t}}\left\{x_{o, j}^{*, \tau}\right\} \quad \text { s.t } \\
& \sum_{i=1}^{n} \lambda_{i} x_{i, j}^{\tau} \leq x_{o, j}^{*, \tau} \\
& \\
& \sum_{i=1}^{n} \lambda_{i} x_{i,-j}^{\tau} \leq x_{o,-j}^{\tau} \quad-j=1, \ldots j-1, j+1, \ldots p \\
& \sum_{i=1}^{n} \lambda_{i} x_{i, D}^{\tau} \leq x_{o, D}^{\tau} \\
& \sum_{i=1}^{n} \lambda_{i} y_{i, r}^{\tau} \geq y_{o, r}^{\tau} \\
& \lambda_{i} \geq 0
\end{aligned}
$$

where $x_{D}$ corresponds to customer deposits which we treat as a non-discretionary input. In the linear programme, while deposits contribute in defining the feasible set in the form of a linear constraint, they do not participate in the optimisation process, in that potential improvements in deposits are not considered.

To obtain the output coordinates we have:

$$
\begin{aligned}
\max _{\lambda, y_{o, r}^{*, t}}\left\{y_{o, r}^{*, \tau}\right\} & \text { s.t } \\
& \sum_{i=1}^{n} \lambda_{i} x_{i, j}^{\tau} \leq x_{o, j}^{*, \tau} \quad j=1, \ldots p \\
& \sum_{i=1}^{n} \lambda_{i} x_{i, D}^{\tau} \leq x_{o, D}^{\tau} \\
& \sum_{i=1}^{n} \lambda_{i} y_{i, r}^{\tau} \geq y_{o, r}^{\tau}
\end{aligned}
$$

\footnotetext{
${ }^{6}$ We have also run the analysis using the ideal reference point definitions as in Asmild et al. (2016). While some differences were observed in the resulting values of productivity change, the conclusions of the paper were not affected. The results of this exercise are available upon request by the authors.
} 


$$
\begin{aligned}
& \sum_{i=1}^{n} \lambda_{i} y_{i,-r}^{\tau} \geq y_{o,-r}^{\tau} \quad-r=1, \ldots r-1, r+1, \ldots q \\
& \lambda_{i} \geq 0
\end{aligned}
$$

If $\left(\boldsymbol{x}_{o}^{*, \tau}, \boldsymbol{y}_{o}^{*, \tau}\right)=\left(\boldsymbol{x}_{o}^{\tau}, \boldsymbol{y}_{o}^{\tau}\right)$, DMU $o$ is technically efficient. Otherwise, the potential improvements in each input and output in the direction of $\left(\boldsymbol{x}_{o}^{*, \tau}, \boldsymbol{y}_{o}^{*, \tau}\right)$ will be identified in the second stage of MEA. The relevant linear programs are presented below for the contemporaneous distance function (left panel) and the cross-period distance function (right panel):

$$
\begin{array}{lll}
\max _{\lambda, \beta}(\beta) & \text { s.t } & \max _{\lambda, \beta}(\beta) \\
\sum_{i=1}^{n} \lambda_{i} x_{i, j}^{\tau} \leq x_{o, j}^{\tau}-\beta\left(x_{o, j}^{\tau}-x_{o, j}^{*, \tau}\right) & \sum_{i=1}^{n} \lambda_{i} x_{i, j}^{\tau} \leq x_{o, j}^{\tau^{\prime}}-\beta\left(x_{o, j}^{\tau^{\prime}}-x_{o, j}^{*, \tau}\right) & j=1, \ldots p \\
\sum_{i=1}^{n} \lambda_{i} y_{i, r}^{\tau} \geq y_{o, r}^{\tau}+\beta\left(y_{o, r}^{*, \tau}-y_{o, r}^{\tau}\right) & \sum_{i=1}^{n} \lambda_{i} y_{i, r}^{\tau} \geq y_{o, r}^{\tau^{\prime}}+\beta\left(y_{o, r}^{*, \tau}-y_{o, r}^{\tau^{\prime}}\right) & r=1, \ldots q \\
\lambda_{i} \geq 0 & \lambda_{i} \geq 0
\end{array}
$$

The efficient level of input $j$ and output $r$ for DMU $o$, can be obtained from (13) as $x_{o, j}^{e f f}=x_{o, j}-$ $\beta\left(x_{o, j}-x_{o, j}^{*}\right)$ and $y_{o, r}^{e f f}=y_{o, r}+\beta\left(y_{o, r}^{*}-y_{o, r}\right)$, respectively. The corresponding input and outputspecific efficiencies can be then calculated as $\theta_{o, j}=\left(x_{o, j}^{e f f} / x_{o, j}\right)$ and $\theta_{o, r}=\left(y_{o, r} / y_{o, r}^{e f f}\right)$. Let us denote with $\theta_{d}^{\tau}\left(x_{o}^{\tau}, y_{o}^{\tau} ; g_{o}^{\tau}\right)$ the contemporaneous efficiency score of DMU $o$ in dimension $d=1, \ldots p+q$, and with $\theta_{d}^{\tau}\left(x_{o}^{\tau^{\prime}}, y_{o}^{\tau^{\prime}} ; g_{o}^{\tau}\right)$ the respective cross-period efficiency in the direction of the ideal reference point defined earlier. Given the definitions above and replacing the directional distance functions in (6) with the dimension-specific efficiencies above, we define the MEA-Malmquist index for DMU $o$ in direction $d$ as:

$$
\begin{aligned}
& M_{o d}\left(x_{o}^{t}, y_{o}^{t}, x_{o}^{t+1}, y_{o}^{t+1}\right) \\
& \qquad=\frac{\theta_{d}^{t+1}\left(x_{o}^{t+1}, y_{o}^{t+1} ; g_{o}^{t+1}\right)}{\theta_{d}^{t}\left(x_{o}^{t}, y_{o}^{t} ; g_{o}^{t}\right)} \cdot\left[\frac{\theta_{d}^{t}\left(x_{o}^{t+1}, y_{o}^{t+1} ; g_{o}^{t}\right)}{\theta_{d}^{t+1}\left(x_{o}^{t+1}, y_{o}^{t+1} ; g_{o}^{t+1}\right)} \cdot \frac{\theta_{d}^{t}\left(x_{o}^{t}, y_{o}^{t} ; g_{o}^{t}\right)}{\theta_{d}^{t+1}\left(x_{o}^{t}, y_{o}^{t} ; g_{o}^{t+1}\right)}\right]^{\frac{1}{2}}
\end{aligned}
$$

It is important to note that we have defined the MEA-Malmquist index so that values exceeding 1 reflect progress in the index or its components, values less than 1 reflect regress, while values equal to 1 indicate no change. That is, instead of replacing the distance functions with their reciprocal efficiency 
scores, we did a direct substitution to obtain more tractable interpretations on productivity change that will be also useful for our beta convergence regressions.

We provide a graphical illustration of the relevant concepts in Figure 1 below. To enable graphical exposition, we use two inputs and one output under the assumption of input orientation, meaning $g_{\tau}\left(y_{r}^{\tau}\right)=0$. The pivoting of the isoquant is introduced to emphasize the failure of radial models in capturing uneven technical change, further motivating the use of directional distance functions and models such as the MEA-Malmquist index used here. In Figure 1, the productivity of input $x_{1}$ declines from period $t$ to period $t+1$, whereas the productivity of input $x_{2}$ increases. For the calculation of the MEA-Malmquist index we can use the potential improvements for $\left(x_{o}^{t}, y_{o}^{t}\right)$ and $\left(x_{o}^{t+1}, y_{o}^{t+1}\right)$ with respect to the frontier in time $t$ or $t+1$. That is, we need to consider either the green arrows pointing towards the ideal reference point $\left(x_{o}^{*, t}, y_{o}^{*, t}\right)$, or the red arrows towards $\left(x_{o}^{*, t+1}, y_{o}^{*, t+1}\right)$. Graphically, productivity increase is observed when the arrows stemming from $\left(x_{o}^{t+1}, y_{o}^{t+1}\right)$ are shorter than their counterparts. Efficiency increase is observed when the red arrow from $\left(x_{o}^{t+1}, y_{o}^{t+1}\right)$ is shorter than the green arrow from $\left(x_{o}^{t}, y_{o}^{t}\right)$. Technical progress, that considers the relative distance of the frontiers from a reference DMU, is observed when the green arrows are shorter than the red arrows that stem from the same point. Finally, to graphically identify the potential improvements for each input, we would need to project each vector (arrow) on the edges of the rectangle formed by the DMU and the respective ideal reference point. 
Figure 1. Multidirectional productivity change

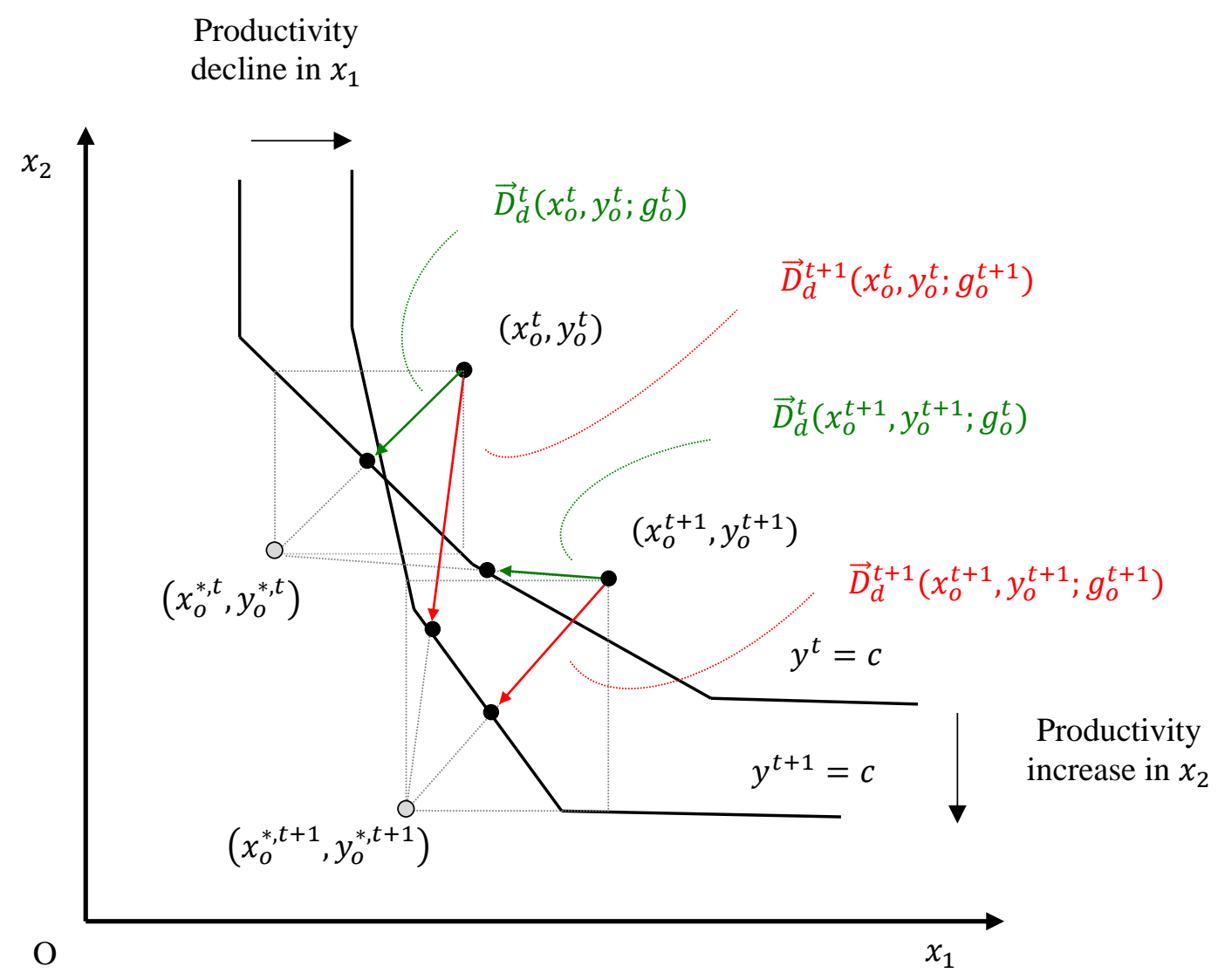

Notes: The figure provides a graphical illustration of the multidirectional productivity change for the case of two inputs and one output. We consider $D M U_{o}$ operating in periods $t\left(x_{o}^{t}, y_{o}^{t}\right)$ and $t+1\left(x_{o}^{t+1}, y_{o}^{t+1}\right)$, respectively. The two isoquants reflect combinations of the two inputs required to produce output quantity $c$ in both periods. The green arrows show the potential improvements with respect to the frontier at time $t$ in the direction of the ideal reference point $\left(x_{o}^{*, t}, y_{o}^{*, t}\right)$. Similarly, the red arrows reflect the potential improvements with respect to the frontier at time $t+1$ in the direction of the ideal reference point $\left(x_{o}^{*, t+1}, y_{o}^{*, t+1}\right)$.

\subsection{Multidirectional conditional convergence}

We propose a novel approach for testing dimension-specific, $\beta$-convergence in productivity, efficiency and technology. Our paper is closest to Casu et al. (2016), Degl'Innocenti et al. (2017) and Fujii et al. (2018), but with the following differences, at least in joint consideration: (i) we examine convergence in productivity and its decompositions, rather than in the growth rate of the respective measures, (ii) we introduce in this context the notion of convergence in technology, (iii) we apply our convergence analysis on each input and output separately, and (iv) we examine for conditional convergence. To our knowledge, this is the first paper to propose such definitions of convergence and their theoretical justifications are offered below. 
Considering the two building blocks of productivity change in (3) and (4) and technical change in (9) and (10), the concept of change is embedded in the ratios. In particular, (3) and (4) examine the change in the distance of a DMU in the two time periods from a certain reference technology, while (9) and (10) consider the change in the distance of a fixed DMU from the two reference technologies. With regards to Figure 1, productivity change can be illustrated by the change in the length of the samecoloured vectors, while technical change is associated with the change in the length of the vectors stemming from each reference DMU. Finally, efficiency change is simply the change in the distance of each DMU from the respective frontier.

We can now provide a technical definition of the concepts of convergence in productivity, efficiency and technology, introduced in section 1. In this context, absolute convergence is achieved when the respective vectors for all DMUs are of the same length; a condition that could be theoretically satisfied in the long run if all DMUs lie on the same frontier. Regarding productivity convergence, this requires that less productive firms exhibit a greater productivity growth than more productive ones. Considering (3), this suggests that firms that initially exhibit a relatively high level of inefficiency $\left(\vec{D}^{t}\left(x_{t}, y_{t} ; g\right)\right)$, will need to ensure that they close up in the future the distance $\left(\vec{D}^{t}\left(x_{t+1}, y_{t+1} ; g\right)\right)$. In fact, inefficient firms will need to make greater leaps in productivity $\left(\vec{D}^{t}\left(x_{t+1}, y_{t+1} ; g\right)-\vec{D}^{t}\left(x_{t}, y_{t} ; g\right)\right)$ to be able to catch up with the more productive firms, while similar arguments can be made using period $t+1$ as the reference technology. If these conditions are all met and thus firms converge in productivity, in the long-run banks will be on a balanced growth path, suggesting convergence in the growth rate of productivity as well; that is, converge towards the value of one for the MEA-Malmquist index in each dimension. ${ }^{7}$ This provides a link between the concepts introduced here with previous studies on convergence in productivity change.

\footnotetext{
7 If absolute convergence is achieved, then $\vec{D}^{t}\left(x_{t+1}, y_{t+1} ; g\right)=\vec{D}^{t}\left(x_{t}, y_{t} ; g\right)$ and $\vec{D}^{t+1}\left(x_{t+1}, y_{t+1} ; g\right)=$ $\vec{D}^{t+1}\left(x_{t}, y_{t} ; g\right)$, which is the case of no productivity change.
} 
Taking natural logarithms in equation (5) and replacing the distance functions with the directional efficiency measures in the way discussed in the previous section, we have for the input or output variable $d$ :

$$
\begin{aligned}
\ln M_{d}\left(x_{t}, y_{t}, x_{t+1}, y_{t+1} ; g\right) & \\
= & \frac{1}{2}\left(\ln \theta_{d}^{t}\left(x_{t+1}, y_{t+1} ; g_{t}\right)-\ln \theta_{d}^{t}\left(x_{t}, y_{t} ; g_{t}\right)+\ln \theta_{d}^{t+1}\left(x_{t+1}, y_{t+1} ; g_{t+1}\right)\right. \\
& \left.-\ln \theta_{d}^{t+1}\left(x_{t}, y_{t} ; g_{t+1}\right)\right)=\frac{1}{2}\left(\ln M_{d}^{t}+\ln M_{d}^{t+1}\right)
\end{aligned}
$$

Considering reference technology $t$, it would be possible to test for convergence in dimension- $d$ productivity as follows:

$$
\ln M_{d}^{t}=\ln \theta_{d}^{t}\left(x_{t+1}, y_{t+1} ; g_{t}\right)-\ln \theta_{d}^{t}\left(x_{t}, y_{t} ; g_{t}\right)=\beta_{0}+\beta_{1} \ln \theta_{d}^{t}\left(x_{t}, y_{t} ; g_{t}\right)+\varepsilon
$$

Similarly, and without change in the notation of regression coefficients for ease of exposition, it is possible to test for dimension- $d$ productivity converge with respect to reference technology $t+1$ as follows:

$$
\begin{gathered}
\ln M_{d}^{t+1}=\ln \theta_{d}^{t+1}\left(x_{t+1}, y_{t+1} ; g_{t+1}\right)-\ln \theta_{d}^{t+1}\left(x_{t}, y_{t} ; g_{t+1}\right) \\
=\beta_{0}+\beta_{1} \ln \theta_{d}^{t+1}\left(x_{t}, y_{t} ; g_{t+1}\right)+\varepsilon
\end{gathered}
$$

To avoid discriminating against a reference period, we test for convergence in productivity on the average of (16) and (17):

$$
\ln M_{d}\left(x_{t}, y_{t}, x_{t+1}, y_{t+1} ; g\right)=\beta_{0}+\beta_{1} \frac{\ln \theta_{d}^{t}\left(x_{t}, y_{t} ; g_{t}\right)+\ln \theta_{d}^{t+1}\left(x_{t}, y_{t} ; g_{t+1}\right)}{2}+\varepsilon
$$

Efficiency convergence is tested using the usual approach in the literature:

$$
\ln E C=\ln \theta_{d}^{t+1}\left(x_{t+1}, y_{t+1} ; g_{t+1}\right)-\ln \theta_{d}^{t}\left(x_{t}, y_{t} ; g_{t}\right)=\beta_{0}+\beta_{1} \ln \theta_{d}^{t}\left(x_{t}, y_{t} ; g_{t}\right)+\varepsilon
$$

Finally, we use the same logic as with convergence in productivity to test for convergence in technology. The key difference here is that the concept of convergence intuitively involves the extent to which the two frontiers close in towards a specific DMU. Considering (10) we can deduce that firms that have a relatively large distance from their frontier in a certain year $\left(\vec{D}^{t+1}\left(x_{t+1}, y_{t+1} ; g\right)\right)$ compared to the previous period's reference technology $\left(\vec{D}^{t}\left(x_{t+1}, y_{t+1} ; g\right)\right)$ will need to catch up faster with the frontier shift in order to reduce the technological gap $\left(\vec{D}^{t}\left(x_{t+1}, y_{t+1} ; g\right)-\vec{D}^{t+1}\left(x_{t+1}, y_{t+1} ; g\right)\right)$ from 
the firms leading change. Similar arguments could be made when DMU $\left(x_{t}, y_{t}\right)$ is used as reference. From equations (9) and (10) and following the same steps as with the case of productivity convergence above, we can test for convergence in technology as follows:

$$
\ln T C=\beta_{0}+\beta_{1} \frac{\ln \theta_{d}^{t+1}\left(x_{t}, y_{t} ; g_{t+1}\right)+\ln \theta_{d}^{t+1}\left(x_{t+1}, y_{t+1} ; g_{t+1}\right)}{2}+\varepsilon
$$

In the regression specifications (18) to (20) above, a negative and statistically significant value for $\beta_{1}$ is evidence of absolute $\beta$-convergence in the respective component and dimension of productivity.

It is also possible to test for conditional convergence, that is, convergence towards different equilibria, in the presence of exogenous influences. To account for conditional convergence, we extend regression models (18) to (20) by including the natural logarithms of the Liquid Assets Ratio and the Capital Adequacy Ratio. If $\beta_{1}$ is negative and statistically significant and $\beta_{2}$ is statistically significant, irrespective of sign, there is evidence of conditional convergence. In the context of banking, for successful integration we would prefer evidence of absolute convergence rather than conditional convergence, in that banks would converge towards a common frontier, instead of local equilibria that may depend on the level of their liquidity and capital adequacy.

\section{Empirical findings}

We now present the empirical findings arising from the multidirectional productivity change and the estimation of (conditional) $\beta$-convergence for SSM-supervised banks, discussed in subsections 4.1 and 4.2, respectively. Policy implications are discussed in subsection 4.3.

\subsection{Multidirectional productivity change}

The results on multidirectional productivity change are presented in Figure 2 and Table 2 below. Figure 2 plots the productivity, efficiency and technical change between consecutive time periods during 2011 to 2017 for an 'Average Bank'. ${ }^{8}$ We find substantial asymmetries in the productivity

\footnotetext{
${ }^{8}$ The Average Bank is an artificial unit and its inputs and outputs correspond to the average values in each respective dimension. This representation captures the average behaviour in the banking sector and is less prone to outliers compared to averaging across banks' efficiency scores. Moreover, results are not affected since the
} 
behaviour of the SSM-supervised banks across dimensions. First, while productivity change appears overall stable around 1, the opposite is true for its two components. In particular, we find that the efficiency improvements that we observe across dimensions are counterbalanced by an equivalent decline in technology. Although the former could be interpreted as evidence of improved managerial practices, we cannot exclude the possibility that the operations of most banks remained largely unchanged and that the improvements in efficiency were due to the inward shifting frontier. Second, the most notable change in behaviour is observed between periods 2013-2014 (point 2013) and 20142015 (point 2014), coinciding with the period after the creation of the SSM. Finally, while banks produce on average similar results for the different dimensions, Other Earning Assets, that mainly include banks' investment activities, exhibit substantial differences, reflecting the multidimensional nature of banking operations. We also observe a substantial dip in performance in Other Earning Assets after 2013 compared to other variables, suggesting that changes in regulation and supervision can have an asymmetric impact on bank productivity.

Figure 2. MEA-Malmquist productivity index and decompositions

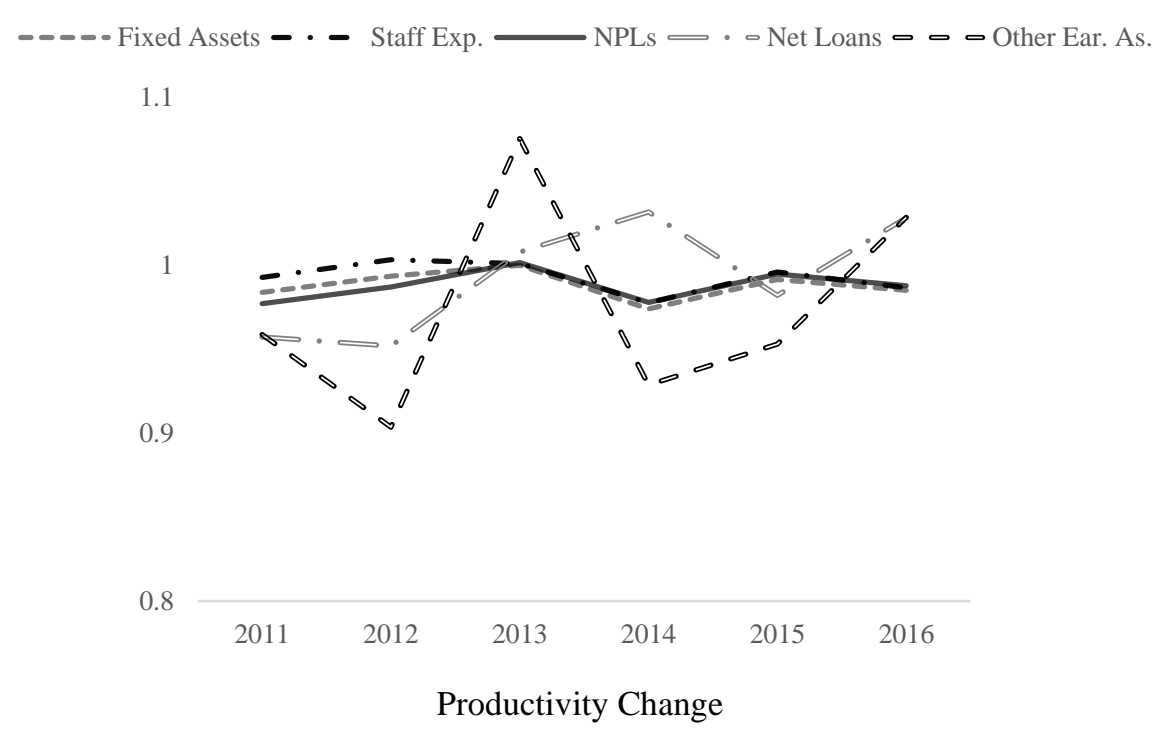

Average Bank is always enveloped within the frontier, by definition (Siriopoulos and Tziogkidis, 2010; Tziogkidis et al., 2018). 


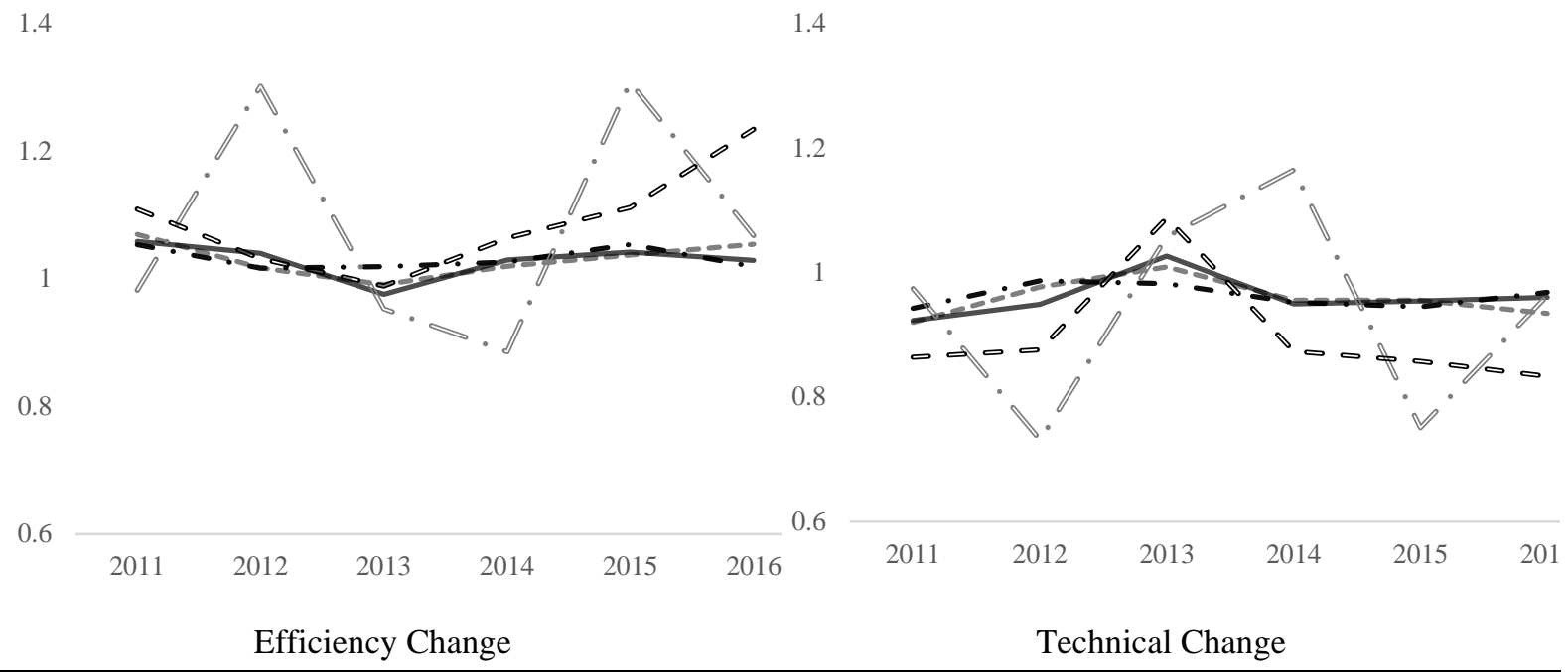

Notes: The figures plot the MEA-Malmquist index for each input and output dimension (top), and for its decomposition into efficiency change (bottom left) and technical change (bottom right). Each patterned line corresponds to a dimension specified on the legend on the top of the figure. Results presented for a given year reflect values of the index from that year to the next one. For example, the MEA-Malmquist index on NPLs for the period 2013 to 2014 can be traced by the position of the solid black line on the top line plot in the position '2013'. Values greater, equal to, or less than one, indicate an increase, no change, or decline, in the respective component. Analytical results for all banks in the sample are provided in the accompanying Supplement.

Given the significance of our results and to further investigate the extent to which 2013 is associated with a substantial change in the behaviour of financial institutions in utilising their resources, we have estimated the MEA-Malmquist index for the whole period (2011-2017), as well as for the two subperiods around 2013 (2011-2013 and 2013-2017). It is important to note that this is a different type of analysis than simply averaging over the respective periods, since the focus is on the relative position of the respective frontiers. For the remainder of the paper we focus our analysis on these periods, while analytical results for annual changes can be found in the accompanying Supplement.

Table 3 below presents the productivity change and its decompositions for the Average Bank during the aforementioned periods of interest. From 2011 to 2017 the frontier shifts inwards, partly attributed to the imposition of additional controls and supervision from the ECB. At the same time, efficiency appears improved, either due to improvements in managerial practices, or due to the inward displacement of the frontier. After the creation of the SSM, these effects are more pronounced, especially for Other Earning Assets, potentially attributed to stricter requirements for investment asset quality and capital adequacy. Considering also Table 1, this can be confirmed by the decreasing average for Other Earning Assets and the simultaneous increase in liquidity and capital adequacy. Similarly, the 
slowdown in technical regress for Net Loans and NPLs, on the one hand, can be attributed to the gradually improving credit conditions is Europe. On the other hand, it is indicative of actions that banks are required to take towards improving asset quality, which is consistent with the decreasing NPLs and the increasing Net Loans we observe in Table 1.

Table 2. Multidirectional productivity change for the Average Bank before and after 2013

\begin{tabular}{|c|c|c|c|c|c|}
\hline & Fixed Assets & $\begin{array}{c}\text { Staff } \\
\text { Expenses }\end{array}$ & NPLs & Net Loans & $\begin{array}{c}\text { Other } \\
\text { Earning } \\
\text { Assets }\end{array}$ \\
\hline \multicolumn{6}{|l|}{$2011-2017$} \\
\hline Productivity Change & 0.976 & 1.013 & 0.973 & 1.013 & 0.938 \\
\hline Efficiency Change & 1.201 & 1.201 & 1.185 & 1.506 & 1.651 \\
\hline Technical Change & 0.813 & 0.844 & 0.822 & 0.673 & 0.568 \\
\hline \multicolumn{6}{|l|}{$2011-2013$} \\
\hline Productivity Change & 0.994 & 1.007 & 0.978 & 0.925 & 0.875 \\
\hline Efficiency Change & 1.088 & 1.071 & 1.101 & 1.278 & 1.144 \\
\hline Technical Change & 0.914 & 0.941 & 0.889 & 0.723 & 0.765 \\
\hline \multicolumn{6}{|l|}{$2013-2017$} \\
\hline Productivity Change & 0.982 & 0.994 & 0.979 & 1.035 & 0.985 \\
\hline Efficiency Change & 1.104 & 1.122 & 1.077 & 1.178 & 1.443 \\
\hline Technical Change & 0.890 & 0.886 & 0.909 & 0.878 & 0.683 \\
\hline
\end{tabular}

Notes: The table presents the MEA-Malmquist index of productivity change for each dimension for the whole period of study, as well for the period before the introduction of the SSM (2011-2013) and after (2013-2017). The reported figures correspond to an average bank, the inputs and outputs of which are the average values in the respective dimension.

\subsection{Convergence analysis}

The results for our $\beta$-convergence analysis are summarised in Figures 3 to 5 and Tables 3 to 5 below. The figures present the kernel densities for the contemporaneous and cross-period efficiencies that participate in the calculation of the MEA-Malmquist index and its components. ${ }^{9}$ Each figure contains density plots for the contemporaneous and cross-period efficiency distributions that comprise the respective productivity components.

In each dimension, a displacement of the red line(s) to the right towards the same-patterned black line(s) indicates an improvement in the respective dimension. From a regulator's perspective, it would

\footnotetext{
${ }^{9}$ Density plots for each component, dimension and time period are provided in the accompanying Supplement.
} 
be desirable for the red-line densities to move towards the black ones. Such movements would reflect an overall improvement in the utilisation of resources (positive efficiency change) and the implementation of regulations which not only do they secure the stability of the financial system, but also are conducive to the adoption of financial innovations and technologies or practices that improve the productivity of banks and hence reduce the costs of financial intermediation (technical progress). Moreover, narrower distributions (and ideally towards 1) imply convergence in the practices followed by commercial banks, while widening distributions suggest divergence due to the increased volatility and therefore uncertainty of operations. Therefore, narrowing and shifting distributions towards 1 provide a desirable behavioural pattern which would imply homogeneity, stability and efficient use of resources.

Considering the behaviour of densities in the figures below we find substantial differences in the shape and position of the dimensional distributions and their components. This suggests that disaggregating productivity change per component and dimension can reveal asymmetries that would otherwise not be possible to examine. Regarding productivity change from 2011 to 2017, we do not obtain a clear picture about the direction and width of distributions, attributed to the almost mirror results obtained with respect to the two reference technologies. This is in line with the results for the Average Bank in Table 2 where productivity change is close to 1 in all dimensions. The clearest pattern emerging is that the distributions for Other Earning Assets become flatter, implying increasing variation and heterogeneity in investment-related operations. When considering the two sub-periods, we obtain similar results, in that the changes in the shape and position of densities is marginal. The only difference we observe is that the aforementioned flattening of the distributions for Other Earning Assets is mainly observed after the creation of the SSM.

With regards to the decompositions of the productivity index, we confirm our earlier finding that efficiency has improved across dimensions and that the frontier has substantially shifted inwards. Indeed, most efficiency distributions exhibit a clear rightward motion, while most densities associated with technical change have moved in the opposite direction. However, in some cases the behaviour of the Average Bank (Table 2) is not entirely reflected on the behaviour of densities, which is attributed to the skewness of the associated distributions. For example, the component densities only marginally 
move for Fixed Assets and Impaired Loans, although we would expect a clearer picture in relation to Table 2.

An important insight we gain by inspecting the figures below, is that, apart from the differences in magnitude we found earlier for the different decompositions and dimensions, we also observe that certain dimensions are associated with more variability compared to others. In particular, both outputs are associated with substantially flatter distributions compared to their inputs. This suggests that banks are more heterogeneous in their operations with respect to credit and investment operations, rather than on their control of staff and capital expenses. Regarding Impaired Loans, we find that their distributions are quite leptokurtic and unimodal, which is indicative of common managerial practices and technology in that dimension, attributed to common supervision and regulatory requirements in the management and reporting of NPLs. There are still banks that deviate considerably from the centre of the distribution, which means that, although impaired loans are treated similarly, the degree of risk tolerance can vary.

A notable observation is that the aforementioned flattening in the second period for Other Earning Assets, is mainly spotted in the respective efficiency distributions. This implies that the variability in the investment-related operations is mainly attributed to changes in managerial practices, potentially in response to the stricter controls imposed that limited the investment activities of banks and which is reflected in the inward shift of the frontier.

Figure 3. Kernel densities of contemporaneous and cross-period efficiencies: 2011-2017

Productivity Change

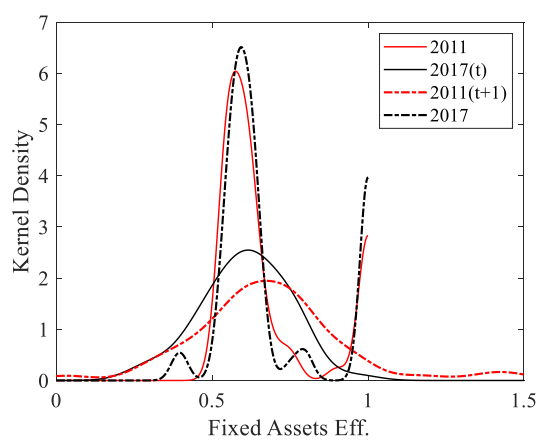

Efficiency change

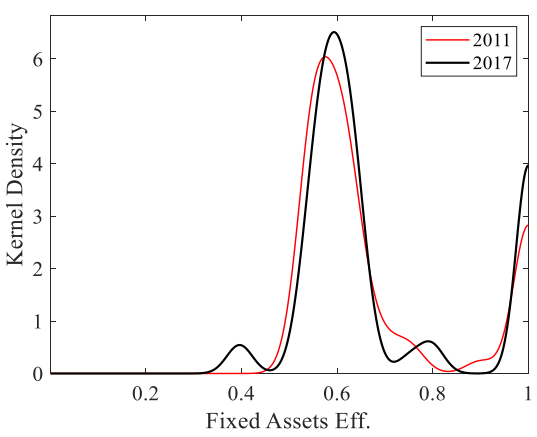

Technical Change

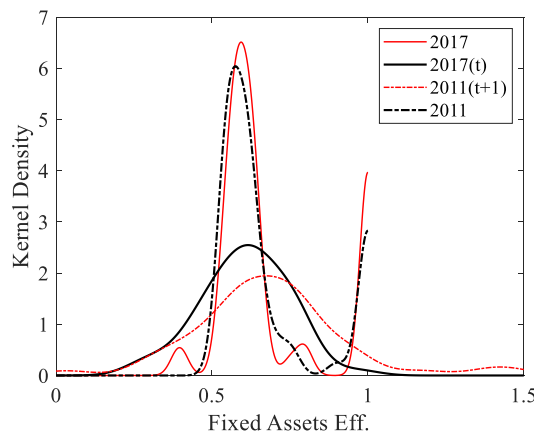



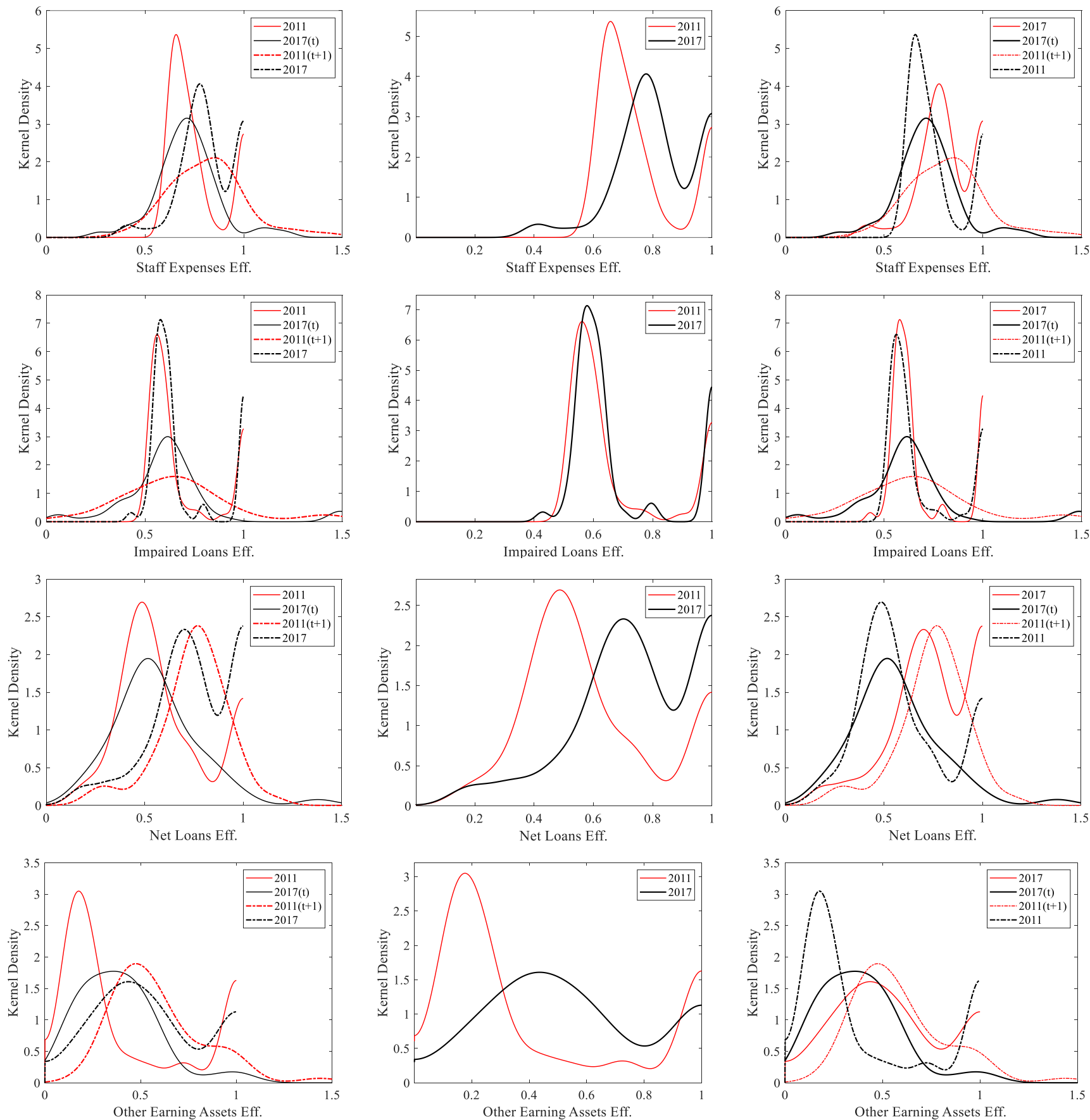

Notes: The figure plots the kernel densities of the efficiencies and cross-period efficiencies used in the calculation of productivity change (first column), efficiency change (column 2) and technical change (column 3) for each input and output dimension as indicated on the axes of the plots in each row. The time periods considered are clearly indicated, while $t$ and $t+1$ are used in cross-period computations reflect the respective reference technology. 
Figure 4. Kernel densities of contemporaneous and cross-period efficiencies: 2011-2013

Productivity Change
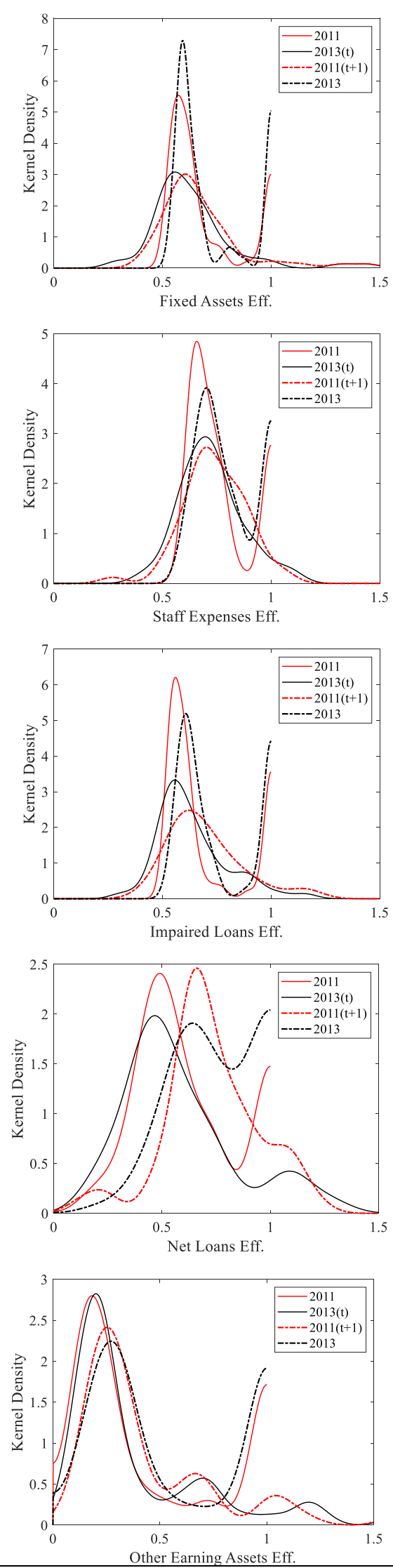

Efficiency change
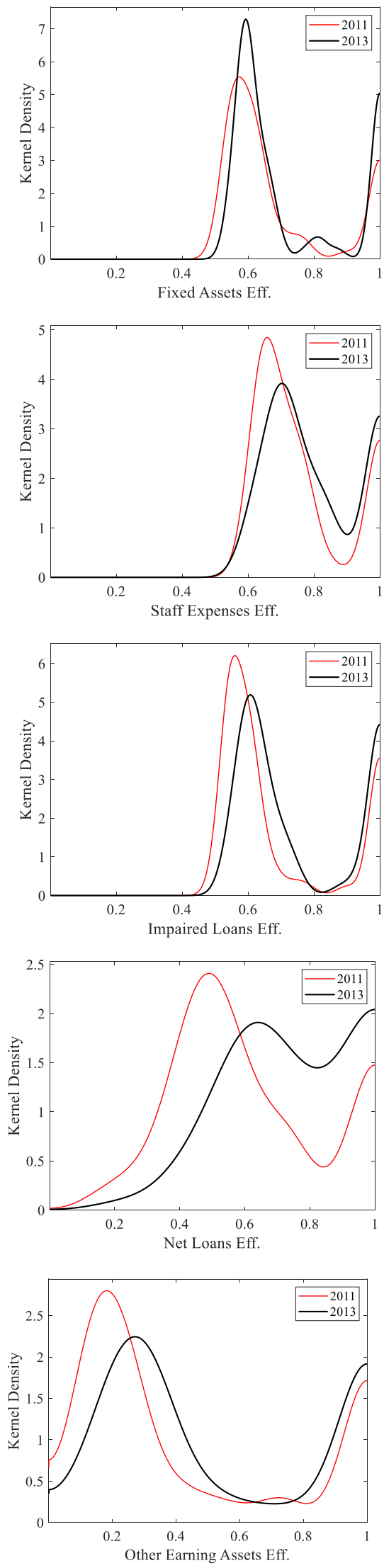

Technical Change
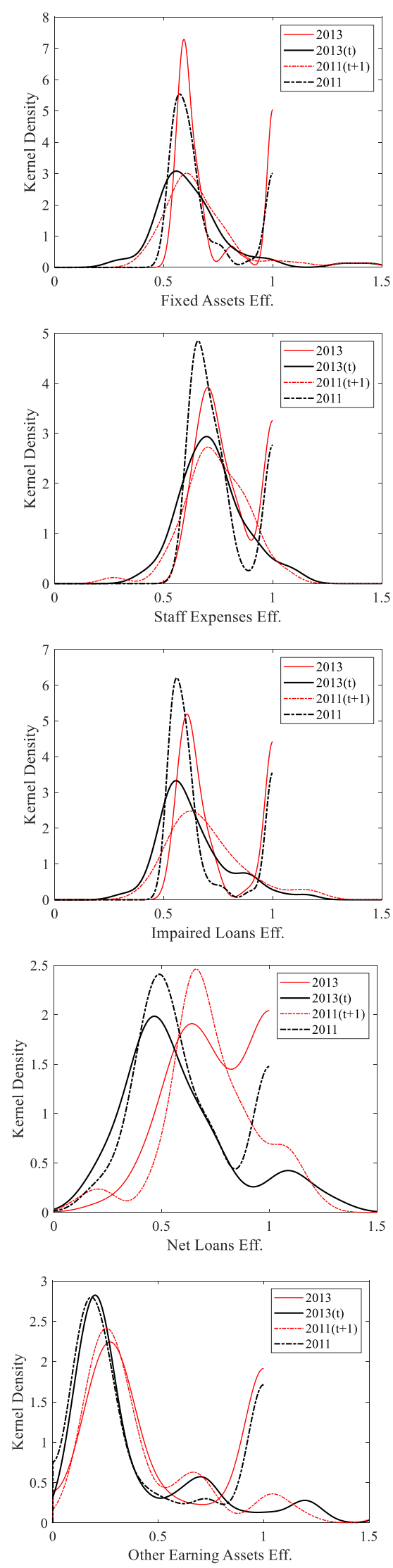

Notes: Please refer to the notes of Figure 3. 
Figure 5. Kernel densities of contemporaneous and cross-period efficiencies: 2013-2017

Productivity Change
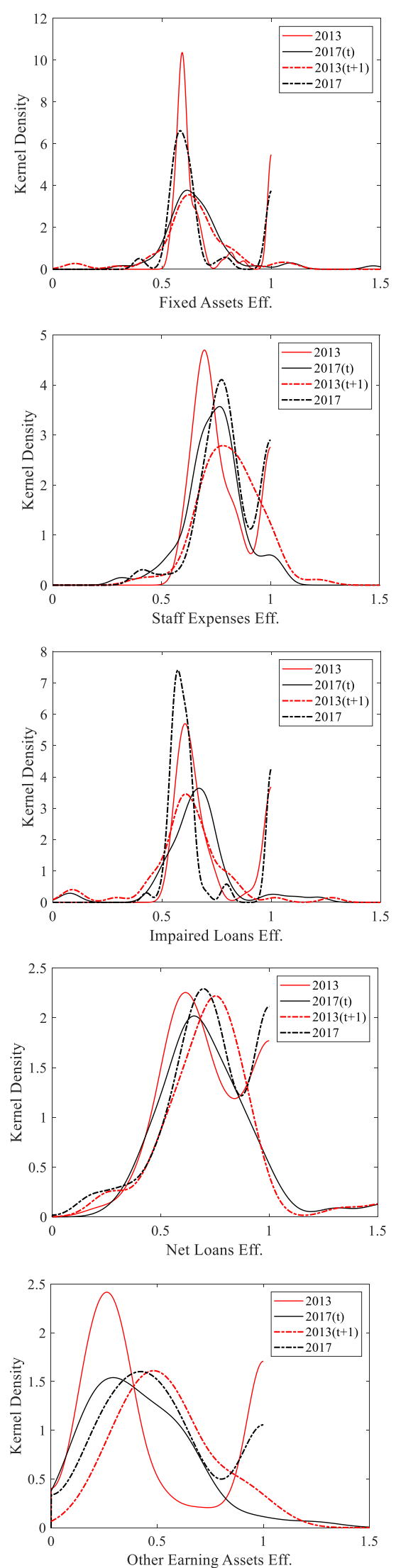

Efficiency change
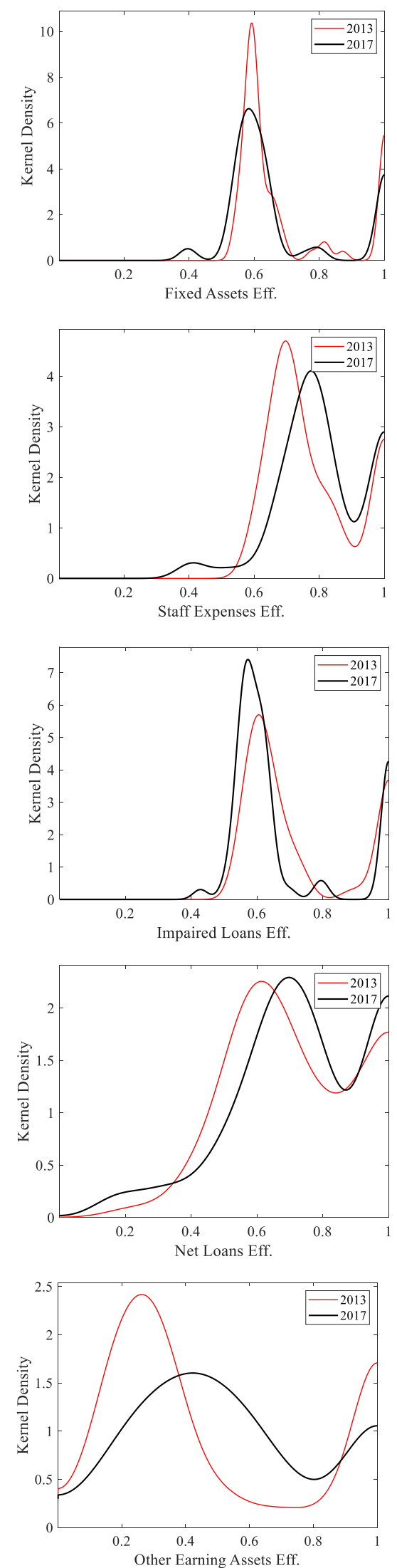

Technical Change
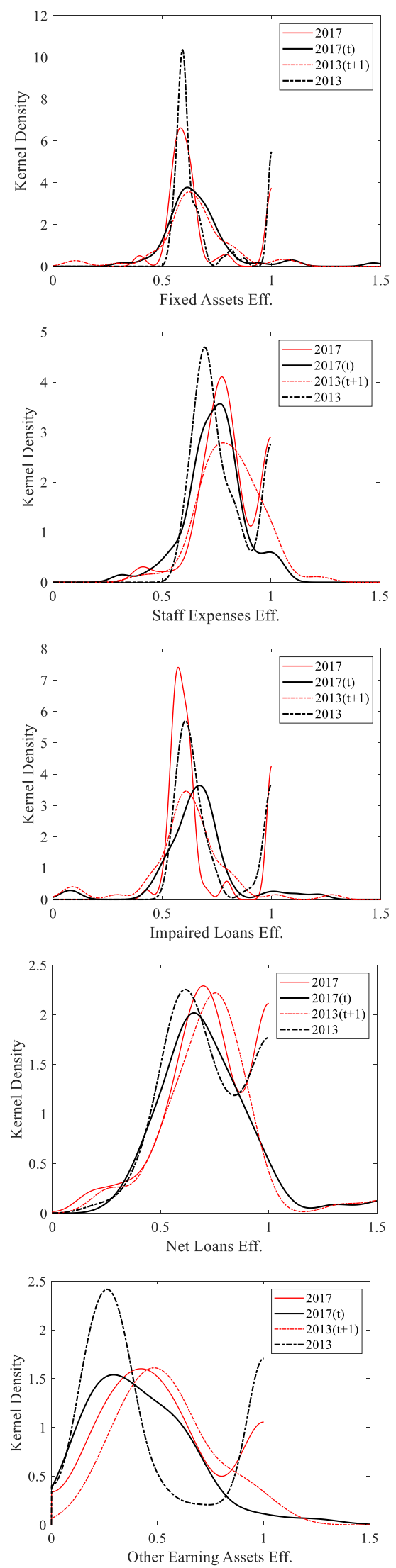

Notes: Please refer to the notes of Figure 3. 
The results for the absolute and conditional $\beta$-convergence tests are presented in Tables 3 to 5 below, for each period considered. Each table is split in column-wise sections that present results for convergence in productivity, efficiency and technology, while the three horizontal sections correspond to the absolute and conditional convergence tests. With the exception of Net Loans, we find strong evidence of absolute convergence in productivity in all dimensions, indicated by the negative and statistically significant slope coefficients. Considering the two decompositions, although efficiency converge is observed across dimensions, the convergence in technology is only statistically significant for Fixed Assets, Staff Expenses and NPLs.

Including the Liquid Assets Ratio (LAR) or the Capital Adequacy Ratio (CAR) in our convergence regressions does not produce any statistically significant results and, therefore, the hypothesis of conditional convergence cannot be accepted in this context. This suggests that there is evidence of convergence towards a common frontier, which is not influenced by the level of liquidity and capital adequacy that banks maintain. The fact that banks do not converge towards local equilibria and have a common direction instead, is evidence supportive of integration in the European banking sector.

Table 3. Beta convergence results for the period 2011-2017

\begin{tabular}{|c|c|c|c|c|c|c|c|c|c|}
\hline \multirow{2}{*}{$2011-2017$} & \multicolumn{3}{|c|}{ Convergence in Productivity } & \multicolumn{3}{|c|}{ Convergence in Efficiency } & \multicolumn{3}{|c|}{ Convergence in Technology } \\
\hline & $\beta_{0}$ & $\beta_{1}$ & & $\beta_{0}$ & $\beta_{1}$ & & $\beta_{0}$ & $\beta_{1}$ & \\
\hline Fixed Assets & $-0.549 * * *$ & $-1.179 * * *$ & & $-0.129 * *$ & $-0.284 * *$ & & $-0.506^{* * *}$ & $-1.080 * * *$ & \\
\hline Staff Expenses & $-0.330 * * *$ & $-1.084 * * *$ & & -0.044 & $-0.374 * *$ & & $-0.261 * * *$ & $-0.646 * * *$ & \\
\hline NPLs & $-0.464 * * *$ & $-0.920 * * *$ & & $-0.173 * * *$ & $-0.392 * * *$ & & $-0.346^{* * *}$ & $-0.670 * * *$ & \\
\hline $\begin{array}{l}\text { Net Loans } \\
\text { Other Earn. }\end{array}$ & -0.043 & -0.010 & & 0.080 & $-0.254 * * *$ & & $-0.259 * * *$ & 0.077 & \\
\hline $\begin{array}{l}\text { Liquid Assets } \\
\text { Ratio }\end{array}$ & $\beta_{0}$ & $\beta_{1}$ & $\beta_{2}$ & $\beta_{0}$ & $\beta_{1}$ & $\beta_{2}$ & $\beta_{0}$ & $\beta_{1}$ & $\beta_{2}$ \\
\hline Fixed Assets & $-0.632 * * *$ & $-1.194 * * *$ & 0.029 & -0.094 & $-0.272 * *$ & -0.011 & $-0.596 * * *$ & $-1.095 * * *$ & 0.032 \\
\hline Staff Expenses & -0.231 & $-1.027 * * *$ & -0.031 & 0.103 & $-0.334 * *$ & -0.051 & $-0.211 * *$ & $-0.628 * * *$ & -0.017 \\
\hline NPLs & -0.312 & $-0.910 * * *$ & -0.056 & -0.139 & $-0.377 * * *$ & -0.010 & -0.279 & $-0.671 * * *$ & -0.025 \\
\hline $\begin{array}{l}\text { Net Loans } \\
\text { Other Earn. }\end{array}$ & -0.162 & -0.001 & 0.047 & 0.223 & $-0.258 * * *$ & -0.055 & $-0.530^{* * *}$ & 0.108 & $0.107^{* *}$ \\
\hline Assets & 0.017 & $-0.267 * * *$ & -0.109 & 0.371 & $-0.386 * * *$ & -0.138 & $-0.878 * * *$ & -0.023 & $0.120 *$ \\
\hline $\begin{array}{l}\text { Capital Adequacy } \\
\text { Ratio }\end{array}$ & $\beta_{0}$ & $\beta_{1}$ & $\beta_{2}$ & $\beta_{0}$ & $\beta_{1}$ & $\beta_{2}$ & $\beta_{0}$ & $\beta_{1}$ & $\beta_{2}$ \\
\hline Fixed Assets & $-0.589 * * *$ & $-1.186^{* * *}$ & 0.004 & -0.082 & $-0.261 * *$ & -0.004 & $-0.566 * * *$ & $-1.087 * * *$ & 0.006 \\
\hline
\end{tabular}




\begin{tabular}{lccccccccc} 
Staff Expenses & $-0.302 * * *$ & $-1.057 * * *$ & -0.002 & -0.007 & $-0.358 * *$ & -0.003 & $-0.225 * * *$ & $-0.618 * * *$ & -0.003 \\
NPLs & $-0.430 * * *$ & $-0.912 * * *$ & -0.003 & $-0.183 * *$ & $-0.396 * * *$ & 0.001 & $-0.313 * *$ & $-0.664 * * *$ & -0.003 \\
$\begin{array}{l}\text { Net Loans } \\
\begin{array}{l}\text { Other Earn. } \\
\text { Assets }\end{array}\end{array}$ & -0.083 & -0.009 & 0.004 & 0.125 & $-0.251 * * *$ & -0.005 & $-0.352 * * *$ & 0.085 & 0.010 \\
& -0.206 & $-0.306 * * *$ & -0.011 & 0.096 & $-0.428 * * *$ & -0.015 & $-0.634 * *$ & 0.019 & 0.011 \\
\hline
\end{tabular}

Notes: The table presents the estimated coefficients for absolute $\beta$-convergence in the upper section, and conditional $\beta$ convergence in the middle and bottom sections, for each input-output dimension. The results for convergence in productivity, in efficiency and in technology are organised in the three vertical sections, indicated by the respective headings. Three stars (***), two stars (**) and one star $(*)$ denote statistical significance at the $1 \%, 5 \%$ and $10 \%$ level, respectively. Analytical results for each adjacent time period can be found in the accompanying Supplement.

Table 4 below presents the results for the period before 2013. Contrary to the full period, we do not find evidence of productivity convergence for Other Earning Assets or efficiency convergence for the two inputs, while for the case of technology the results are similar. Since there is evidence of convergence in technology for Fixed Assets and Staff Expenses, we deduce that the convergence in productivity observed for inputs during 2011-2013 is mainly driven by technological change, albeit towards a lower level. Regarding outputs, convergence is only found for the case of efficiency change, while for NPLs we find evidence of convergence in all elements.

Considering conditional convergence, we find substantially different results compared to the full period. In particular, we find many instances where the coefficients for both the exogenous regulatory variables $\left(\beta_{3}\right)$ and the slope coefficients in convergence regressions $\left(\beta_{2}\right)$ are statistically significant at the same time. Additional liquidity seems to facilitate productivity growth in NPLs, mainly through its effect on technical change. Moreover, liquidity has a positive influence on the efficiency change for Net Loans and a negative one for Other Earning Assets. ${ }^{10}$ The implication arising is that, while additional liquidity has induced banks to become more efficient in extending loans, it has a deceleration effect in the efficiency convergence for investments, suggesting complementarity between the two outputs. At the same time, greater liquidity seems to be associated with technical progress in NPLs, indicating that banks do not necessarily use their additional liquidity to provide loans to riskier customers. Our findings

\footnotetext{
${ }^{10}$ It is useful to remind the readers that the dependent variables used to test for convergence in productivity, efficiency and technology in equations (18) to (20) are the natural logarithms of the Malmquist index of productivity change and its decomposition into efficiency change and technical change, respectively.
} 
suggest that, during 2011-2013, different levels of liquidity tend to induce banks to converge towards different equilibria instead of a common one.

Considering capital adequacy, we also find strong evidence of conditional convergence in productivity (for the two inputs and NPLs), in efficiency (for Staff Expenses, NPLs and Net Loans), as well as in technology (for Fixed Assets and NPLs). Therefore, the conditional convergence in productivity for the two inputs is mainly driven by technology for Fixed Assets and efficiency for Staff Expenses. While there is no straightforward implication arising from this observation, it could be argued that better capitalised banks also take care in controlling their inputs. Notably, for the case of NPLs, capital adequacy has a positive influence not only on productivity growth, but for the two decompositions as well. This implies that banks with a higher Capital Adequacy Ratio tend to improve the management of their NPLs and at the same time expand the frontier in doing so. Given the results in Table 2, we could argue that, on average, the improvement in the efficiency of NPLs was driven by well-capitalised banks, whereas the technological decline in NPLs was mainly driven by less-capitalised banks. On the one hand, this can imply that undercapitalised banks take on additional risks in extending credit to higher risk customers. On the other hand, it could suggest that we are merely capturing a reverse causality effect, in that banks suffering losses and high levels of NPLs due to the debt crisis, are also relatively undercapitalised, which has been a valid observation for the banking systems of the southern EU economies at the time. Finally, taking also into account the positive effect of capital adequacy on the efficiency growth of Net Loans, we could deduce that well-capitalised banks try to maximise the value of their loan portfolios, while minimising their exposure to NPLs, which is evidence of risk aversion.

Table 4. Beta convergence results for the period 2011-2013

\begin{tabular}{|c|c|c|c|c|c|c|}
\hline \multirow{2}{*}{$2011-2013$} & \multicolumn{2}{|c|}{ Convergence in Productivity } & \multicolumn{2}{|c|}{ Convergence in Efficiency } & \multicolumn{2}{|c|}{ Convergence in Technology } \\
\hline & $\beta_{0}$ & $\beta_{1}$ & $\beta_{0}$ & $\beta_{1}$ & $\beta_{0}$ & $\beta_{1}$ \\
\hline Fixed Assets & $-0.373 * * *$ & $-0.793 * * *$ & 0.025 & -0.037 & $-0.391 * * *$ & $-0.775 * * *$ \\
\hline Staff Expenses & $-0.231 * * *$ & $-0.732 * * *$ & 0.029 & -0.072 & $-0.259 * * *$ & $-0.712 * * *$ \\
\hline NPLs & $-0.359 * * *$ & $-0.803 * * *$ & 0.024 & $-0.139 * *$ & $-0.404 * * *$ & $-0.777 * * *$ \\
\hline Net Loans & -0.072 & -0.118 & $0.059 *$ & $-0.294 * * *$ & $-0.240 * * *$ & 0.035 \\
\hline $\begin{array}{l}\text { Other Earn. } \\
\text { Assets }\end{array}$ & -0.087 & -0.103 & 0.016 & $-0.210 * * *$ & $-0.251 * * *$ & 0.004 \\
\hline
\end{tabular}




\begin{tabular}{|c|c|c|c|c|c|c|c|c|c|}
\hline $\begin{array}{l}\text { Liquid Assets } \\
\text { Ratio }\end{array}$ & $\beta_{0}$ & $\beta_{1}$ & $\beta_{2}$ & $\beta_{0}$ & $\beta_{1}$ & $\beta_{2}$ & $\beta_{0}$ & $\beta_{1}$ & $\beta_{2}$ \\
\hline Fixed Assets & $-0.439 * * *$ & $-0.805^{* * *}$ & 0.023 & 0.020 & -0.038 & 0.002 & $-0.450 * * *$ & $-0.786 * * *$ & 0.021 \\
\hline Staff Expenses & $-0.313 * * *$ & $-0.741 * * *$ & 0.030 & -0.011 & -0.084 & 0.014 & $-0.320 * * *$ & $-0.719 * * *$ & 0.022 \\
\hline NPLs & $-0.563 * * *$ & $-0.834 * * *$ & $0.073 * *$ & -0.043 & $-0.168 * *$ & 0.020 & $-0.593 * * *$ & $-0.806^{* * *}$ & $0.068 * *$ \\
\hline Net Loans & $-0.345 * * *$ & -0.074 & $0.111 * * *$ & -0.065 & $-0.292 * * *$ & $0.047 *$ & $-0.421 * * *$ & 0.061 & 0.072 \\
\hline $\begin{array}{l}\text { Other Earn. } \\
\text { Assets }\end{array}$ & 0.347 & -0.039 & $-0.136^{*}$ & $0.444 *$ & $-0.148 * *$ & $-0.131 *$ & $-0.447 * *$ & -0.022 & 0.064 \\
\hline $\begin{array}{l}\text { Capital Adequacy } \\
\text { Ratio }\end{array}$ & $\beta_{0}$ & $\beta_{1}$ & $\beta_{2}$ & $\beta_{0}$ & $\beta_{1}$ & $\beta_{2}$ & $\beta_{0}$ & $\beta_{1}$ & $\beta_{2}$ \\
\hline Fixed Assets & $-0.504 * * *$ & $-0.804 * * *$ & $0.013 * * *$ & 0.004 & -0.046 & 0.002 & $-0.514 * * *$ & $-0.787 * * *$ & $0.013 * *$ \\
\hline Staff Expenses & $-0.319 * * *$ & $-0.751 * * *$ & $0.009^{* *}$ & -0.030 & $-0.094 *$ & $0.005^{* * *}$ & $-0.314 * * *$ & $-0.728 * * *$ & 0.005 \\
\hline NPLs & $-0.506 * * *$ & $-0.821 * * *$ & $0.015 * * *$ & -0.064 & $-0.175 * * *$ & $0.008 * * *$ & $-0.512 * * *$ & $-0.793 * * *$ & $0.011 * *$ \\
\hline Net Loans & $-0.140 *$ & -0.123 & 0.007 & -0.059 & $-0.300 * * *$ & $0.012 * * *$ & $-0.188^{*}$ & 0.048 & -0.005 \\
\hline $\begin{array}{l}\text { Other Earn. } \\
\text { Assets }\end{array}$ & -0.039 & -0.097 & -0.004 & 0.034 & $-0.208 * * *$ & -0.002 & $-0.266 * *$ & 0.003 & 0.001 \\
\hline
\end{tabular}

Notes: Please refer to the notes of Table 3.

When considering the post-2013 period, we find that results differ substantially compared to the preceding period. First, the estimated coefficients for absolute $\beta$-convergence vary in magnitude and significance, but overall there is stronger evidence of convergence. In particular, convergence is additionally found in the productivity of Other Earning Assets, in the efficiency of the two inputs and in the technology of Net Loans. However, the efficiency convergence coefficient for the latter turns insignificant, indicating that banks have shifted focus from the management of Net Loans to the approach they follow in converting their inputs into loans.

The results on conditional convergence are also substantially different. Contrary to the previous period, after the creation of the SSM there are significantly fewer cases where the hypothesis of conditional convergence is confirmed. Especially for LAR, conditional convergence is only observed in two instances as opposed to four previously, while for CAR we find only three cases as opposed to eight. This suggests that after 2013 there is rather evidence of absolute convergence towards a common frontier, instead of conditional convergence towards local equilibria.

Liquidity has a negative effect on productivity growth for Staff Expenses and a positive effect on technological growth for Net Loans. The latter can be attributed to the quantitative easing programme that the ECB announced in March 2015, which improved not only liquidity, but also the "technology" 
of credit extension. The implication here is that promoting liquidity in the market and ensuring broad access to these funds, is conducive to integration.

Regarding capital adequacy, we find evidence of conditional convergence in efficiency for NPLs and Other Earning Assets, while convergence in technology is found for Net Loans. However, there is no evidence for conditional convergence in productivity in any dimension. The positive influence of capital adequacy on the technological growth of Net Loans indicates that, after 2013, better capitalised banks exhibit higher rates of technical growth in generating loans. Moreover, these banks also tend to experience lower rates of growth in the efficiency of managing their impaired loans or investments, given the negative impact on the growth rate of efficiency on NPLs and Other Earning Assets. A potential explanation is that banks may maintain high capital adequacy at the expense of expanding investments, in that they become more selective with the quality of investments due to the narrow Tier1 capital definitions. They therefore switch to loan operations, and given the additional liquidity stemming from ECB's QE programme, they inevitably end up including in their loan portfolios riskier customers.

Table 5. Beta convergence results for the period 2013-2017

\begin{tabular}{|c|c|c|c|c|c|c|c|c|c|}
\hline \multirow{2}{*}{$2013-2017$} & \multicolumn{3}{|c|}{ Convergence in Productivity } & \multicolumn{3}{|c|}{ Convergence in Efficiency } & \multicolumn{3}{|c|}{ Convergence in Technology } \\
\hline & $\beta_{0}$ & $\beta_{1}$ & & $\beta_{0}$ & $\beta_{1}$ & & $\beta_{0}$ & $\beta_{1}$ & \\
\hline Fixed Assets & $-0.452 * * *$ & $-1.020 * * *$ & & $-0.121 * *$ & $-0.195^{*}$ & & $-0.367 * * *$ & $-0.875 * * *$ & \\
\hline Staff Expenses & $-0.157 * * *$ & $-0.500 * * *$ & & -0.039 & $-0.254 *$ & & $-0.137 * * *$ & $-0.310 * * *$ & \\
\hline NPLs & $-0.268 * * *$ & $-0.656 * * *$ & & $-0.197 * * *$ & $-0.313^{* * *}$ & & $-0.135^{*}$ & $-0.479 * * *$ & \\
\hline Net Loans & -0.037 & -0.093 & & -0.043 & -0.117 & & $-0.115^{* * *}$ & $-0.294 * * *$ & \\
\hline $\begin{array}{l}\text { Other Earn. } \\
\text { Assets }\end{array}$ & $-0.273 * * *$ & $-0.227 * * *$ & & -0.117 & $-0.346 * * *$ & & $-0.376 * * *$ & -0.042 & \\
\hline Liquid Assets Ratio & $\beta_{0}$ & $\beta_{1}$ & $\beta_{2}$ & $\beta_{0}$ & $\beta_{1}$ & $\beta_{2}$ & $\beta_{0}$ & $\beta_{1}$ & $\beta_{2}$ \\
\hline Fixed Assets & $-0.545^{* * *}$ & $-1.044 * * *$ & 0.032 & -0.112 & $-0.191 *$ & -0.003 & $-0.452 * * *$ & $-0.897 * * *$ & 0.029 \\
\hline Staff Expenses & 0.043 & $-0.368 * *$ & $-0.064 * *$ & 0.094 & -0.190 & $-0.044 *$ & -0.071 & $-0.284 * * *$ & -0.023 \\
\hline NPLs & -0.259 & $-0.656 * * *$ & -0.003 & $-0.196^{*}$ & $-0.312 * * *$ & 0.000 & -0.183 & $-0.481 * * *$ & 0.018 \\
\hline Net Loans & -0.095 & -0.096 & 0.022 & 0.162 & -0.090 & $-0.075^{*}$ & $-0.353^{* * *}$ & $-0.284 * * *$ & $0.093^{* * *}$ \\
\hline $\begin{array}{l}\text { Other Earn. } \\
\text { Assets }\end{array}$ & $-0.430 * *$ & $-0.249 * * *$ & 0.053 & -0.162 & $-0.352 * * *$ & 0.015 & $-0.664 * * *$ & -0.083 & $0.100 * *$ \\
\hline $\begin{array}{l}\text { Capital Adequacy } \\
\text { Ratio }\end{array}$ & $\beta_{0}$ & $\beta_{1}$ & $\beta_{2}$ & $\beta_{0}$ & $\beta_{1}$ & $\beta_{2}$ & $\beta_{0}$ & $\beta_{1}$ & $\beta_{2}$ \\
\hline Fixed Assets & -0.237 & $-1.006 * * *$ & -0.077 & 0.327 & -0.139 & $-0.155^{* *}$ & -0.367 & $-0.875^{* * *}$ & 0.000 \\
\hline Staff Expenses & 0.129 & $-0.447 * * *$ & -0.100 & 0.238 & -0.215 & -0.097 & -0.094 & $-0.305^{* * *}$ & -0.016 \\
\hline NPLs & 0.198 & $-0.631 * * *$ & -0.166 & 0.194 & $-0.254 * *$ & $-0.135^{*}$ & 0.038 & $-0.472 * * *$ & -0.062 \\
\hline
\end{tabular}




$\begin{array}{lccccccccc}\text { Net Loans } & -0.308 & -0.095 & 0.099 & 0.323 & -0.101 & -0.132 & -0.739 * * * & -0.289 * * * & 0.230^{* *} \\ \text { Other Earn. } & -0.087 & -0.230 * * * & -0.069 & 1.088^{* *} & -0.343 * * * & -0.440 * * * & -1.575 * * * & 0.005 & 0.451 * * * \\ \text { Assets } & & & & \end{array}$

Notes: Please refer to the notes of Table 3.

\subsection{Policy implications}

There are important implications arising from our analysis which may be useful to policy makers. First, the fact that SSM-supervised banks exhibit, in principle, efficiency improvements, though technological deterioration, indicates that although banks use their resources more efficiently, they have fewer options to do so. Technical regress in banking has been linked with the imposition of prudential regulations and managerial controls, effectively rising the costs of financial intermediation (Tziogkidis et al., 2018). The higher costs may be passed on to the consumers. In addition, banks would need to operate under narrow profit margins, mainly by exploiting economies of scale. This could eventually induce consolidation in the banking sector, as the smaller banks would find it difficult to compete with the bigger ones, deteriorating the competitiveness in the sector. Given the above, our analysis indicates that policy makers should provide commercial banks with incentives for innovation, while maintaining a healthy level of regulatory insight.

Second, we find substantial asymmetries in the behaviour of the element-wise productivity and its decompositions. In particular, despite the fact that the banks included in our sample exhibit similar operational characteristics, the variability observed in the distributions in most dimensions considered is indicative of heterogeneities attributable to differences in technology across banking sectors (Bos and Schmiedel, 2007; Kontolaimou et al., 2012), or due to other country-specific factors. For example, some banks seem to be less risk averse, given their approach with respect to NPLs, while others are more risk averse and therefore extend credit more cautiously. Similarly, the degree of investment activities and the related risk exposures can also vary substantially among banks. This also highlights the need to examine productivity by dimension and component rather than on an aggregated level, in order to identify key areas for improvement and policy intervention. Therefore, it is recommended that policy takes into account the country-level or bank-specific characteristics, and exercises control in a more discretional way rather than following an "one-size-fits-all" type of policy. The ECB could identify the 
specific regulatory and supervisory tasks which could be undertaken locally, in order to implement tailored controls that would promote faster convergence and integration.

Third, we find strong evidence of conditional convergence with respect to liquidity, one of the fundamental resources for the extension of loans and which has been increasingly scarce due to the debt crisis in Europe. Before the creation of the SSM, we find that liquidity is conducive to convergence in loans and NPLs, while after 2013, and due to the QE programme of the ECB, additional liquidity seems to facilitate technical growth in loans. This suggests that liquidity plays an important role for growth and that maintaining a common level across banks is conducive to integration. We therefore argue that the implementation of the minimum liquidity coverage ratio in 2014 by the $\mathrm{ECB}$, in line with the recommendations of Basel III, facilitates integration. However, the exclusion of systemic banks from the QE programme of the ECB during the European debt crisis impedes the integration process and, therefore, alternative mechanisms need to be explored.

Finally, similar arguments can be made about capital adequacy, which is also of regulatory significance and of high importance in maintaining financial stability. Well-capitalised banks achieve higher rates of performance improvement with respect to loans and NPLs before 2013, whereas after the creation of the SSM and the additional regulatory requirements that followed, the influence on NPLs on performance is negative while a complementarity effect appears for investments. The implication is that the stricter regulatory oversight and controls after 2013 have affected the behaviour of banking institutions, which are becoming increasingly careful with the quality of their investment assets. This, however, combined with the additional liquidity from the ECB through the QE programme, seems to induce additional risk-taking on loans in order to achieve a good rate of return for their shareholders. The implication is that the additional regulatory controls and requirements, combined with the extension of cheap credit have induced banks to shift riskiness in other directions, which should be taken into account by policy makers when implementing reforms.

Overall, our analysis indicates that European banks have been converging towards a common frontier during the period from 2011 to 2017 and that the policy interventions after 2013 have facilitated this absolute convergence. However, despite the fact that regulation has enabled integration, this paper 
has also identified shortcomings that need to be taken into account by policy makers when considering sector reforms.

\section{Conclusions}

The paper examines the productivity and convergence behaviour of the European banks supervised directly by the SSM during the period from 2011 to 2017. This period marks the creation of the SSM by the ECB, the implementation of regulatory reforms, as well as the European debt crisis, among others. We apply a variant of the MEA-Malmquist index of productivity change to estimate the growth rate in productivity and its two main components, efficiency change and technical change, for each input and output dimension, separately. We then propose a novel approach for measuring and estimating $\beta$-convergence in each component and dimension of productivity, thereby introducing the notion of convergence in technology. Our analysis, therefore, allows examining for behavioural patterns in the productivity and convergence of financial institutions for various aspects of their operations. Finally, we test for conditional convergence by accounting for the effect of liquidity and capital adequacy on convergence behaviour.

We find that despite the fact that commercial banks have improved significantly their resource utilisation (efficiency change) on average, their productive capabilities have deteriorated across inputs and outputs (frontier shift). The greatest variability in productivity change is observed for Other Earning Assets after 2013, which mainly include investment securities, suggesting that policy changes have mostly affected the investment behaviour of banks. Such asymmetric patterns are also observed when examining the associated kernel densities which have different shapes across the various dimensions and decompositions of productivity, suggesting that banks exhibit substantial variability in their operations. We therefore argue that this type of analysis by component and dimension offers additional insights in the examination of bank productivity.

Our convergence analysis shows that the less productive banks converge across dimensions in at least one component of productivity, during the period of study. Moreover, the statistically insignificant results on conditional convergence indicate that banks tend to converge towards a common frontier rather than local equilibria. However, when considering the two sub-periods the results are substantially 
different. In particular, while there is strong evidence of conditional convergence with respect to liquidity and capital adequacy before 2013, the opposite is true in the following period. We conclude that 2013, that marks the creation of the SSM and the imposition of stricter controls and supervision, is a breakpoint which enabled absolute convergence. Overall, we argue that the minimum requirements on liquidity and capital adequacy implemented after 2013, have enabled the banking sector to move towards a common direction and achieve convergence.

However, there important implications arising from the imposition of additional requirements on liquidity and capital adequacy that call for careful consideration in the implementation of such policies. Although liquidity is found to facilitate integration, restricting access to $\mathrm{QE}$ funds for banks that face liquidity constraints due to a crisis, can have a negative impact on bank operations and integration. Similarly, strict capital requirements and regulatory capital criteria can induce banks to seek higher returns for their shareholders from alternative options that may include loans, hence burdening the financial system with more impaired loans. Therefore, while a common level of liquidity and capital adequacy would be conducive to integration, designing such policies would require careful consideration.

\section{References}

Asmild, M., Baležentis, T., Hougaard, J.L., 2016. Multi-directional productivity change: MEAMalmquist. Journal of Productivity Analysis 46, 109-119. https://doi.org/10.1007/s11123-0160486-y

Asmild, M., Hougaard, J.L., Kronborg, D., Kvist, H.K., 2003. Measuring inefficiency via potential improvements. Journal of Productivity Analysis 19, 59-76. https://doi.org/10.1023/A:1021822103696

Asmild, M., Matthews, K., 2012. Multi-directional efficiency analysis of efficiency patterns in Chinese banks 1997-2008. European Journal of Operational Research 219, 434-441. https://doi.org/10.1016/j.ejor.2012.01.001

Assaf, G.A., Matousek, R., Tsionas, E.G., 2013. Turkish bank efficiency: Bayesian estimation with undesirable outputs. Journal of Banking and Finance 37, 506-517. 
https://doi.org/10.1016/j.jbankfin.2012.09.009

Atkinson, S.E., Tsionas, M.G., 2016. Directional distance functions: Optimal endogenous directions. Journal of Econometrics 190, 301-314. https://doi.org/10.1016/j.jeconom.2015.06.006

Barro, R.J., Sala-i-Martin, X., 1992. Convergence. Journal of Political Economy 100, 223-251.

Baumol, W.J., 1986. Productivity growth, convergence, and welfare: What the long-run data show. American Economic Review 76, 1072-1085.

Berger, A.N., Humphrey, D.B., 1992. Measurement and efficiency issues in commercial banking, in: Griliches, Z. (Ed.), Output Measurement in the Service Sectors. National Bureau of Economic Research, pp. 245-300.

Bogetoft, P., Hougaard, J.L., 1999. Efficiency evaluations based on potential (non-proportional) improvements. Journal of Productivity Analysis 12, 233-247. https://doi.org/10.1023/A:1007848222681

Bos, J.W.B., Schmiedel, H., 2007. Is there a single frontier in a single European banking market? Journal of Banking and Finance 31, 2081-2102. https://doi.org/10.1016/j.jbankfin.2006.12.004

Briec, W., Kerstens, K., 2009. Infeasibility and directional distance functions with application to the determinateness of the Luenberger productivity indicator. Journal of Optimization Theory and Applications 141, 55-73. https://doi.org/10.1007/s10957-008-9503-2

Casu, B., Girardone, C., 2010. Integration and efficiency convergence in EU banking markets. Omega 38, 260-267. https://doi.org/10.1016/j.omega.2009.08.004

Casu, B., Ferrari, A., Girardone, C., Wilson, J.O.S., 2016. Integration, productivity and technological spillovers: Evidence for eurozone banking industries. European Journal of Operational Research 255, 971-983. https://doi.org/10.1016/j.ejor.2016.06.007

Chambers, R.G., Chung, Y., Färe, R., 1998. Profit, directional distance functions, and Nerlovian efficiency. Journal of Optimization Theory and Applications 98, 351-364. https://doi.org/10.1023/A:1022637501082

Debreu, G., 1951. The coefficient of resource utilization. Econometrica 19, 273-292. https://doi.org/10.2307/1906814

Degl'Innocenti, M., Kourtzidis, S.A., Sevic, Z., Tzeremes, N.G., 2017. Bank productivity growth and 
convergence in the European Union during the financial crisis. Journal of Banking and Finance 75, 184-199. https://doi.org/10.1016/j.jbankfin.2016.11.016

Färe, R., Grosskopf, S., Noh, D.W., Weber, W., 2005. Characteristics of a polluting technology: Theory and practice. Journal of Econometrics 126, 469-492. https://doi.org/10.1016/j.jeconom.2004.05.010

Farrell, M.J., 1957. The measurement of productive efficiency. Journal of the Royal Statistical Society. Series A (General) 120, 253-290. https://doi.org/10.2307/2343100

Fethi, M.D., Pasiouras, F., 2010. Assessing bank efficiency and performance with operational research and artificial intelligence techniques: A survey. European Journal of Operational Research 204, 189-198. https://doi.org/10.1016/j.ejor.2009.08.003

Fujii, H., Managi, S., Matousek, R., Rughoo, A., 2018. Bank efficiency, productivity, and convergence in EU countries: a weighted Russell directional distance model. European Journal of Finance 24, 135-156. https://doi.org/10.1080/1351847X.2017.1303527

Fukuyama, H., Matousek, R., 2017. Modelling bank performance: A network DEA approach. European Journal of Operational Research 259, 721-732. https://doi.org/10.1016/j.ejor.2016.10.044

Goddard, J., Molyneux, P., Wilson, J.O.S., 2015. Banking in the European Union, in: Berger, A.N., Molyneux, P., Wilson, J.O.S. (Eds.), The Oxford Handbook of Banking. Oxford University Press, Oxford, pp. 849-872.

Holod, D., Lewis, H.F., 2011. Resolving the deposit dilemma: A new DEA bank efficiency model. Journal of Banking and Finance 35, 2801-2810. https://doi.org/10.1016/j.jbankfin.2011.03.007

Kontolaimou, A., Kounetas, K., Mourtos, I., Tsekouras, K., 2012. Technology gaps in European banking: Put the blame on inputs or outputs? Economic Modelling 29, 1798-1808. https://doi.org/10.1016/j.econmod.2012.05.028

Mamatzakis, E., Staikouras, C., Koutsomanoli-Filippaki, A., 2008. Bank efficiency in the new European Union member states: Is there convergence? International Review of Financial Analysis 17, 1156-1172. https://doi.org/10.1016/j.irfa.2007.11.001

Matousek, R., Rughoo, A., Sarantis, N., George Assaf, A., 2015. Bank performance and convergence 
during the financial crisis: Evidence from the "old" European Union and Eurozone. Journal of Banking and Finance 52, 208-216. https://doi.org/10.1016/j.jbankfin.2014.08.012

Sealey, A.C.W., Lindley, J.T., 1977. Inputs, outputs, and a theory of production and cost at depository financial institutions. Journal of Finance 32, 1251-1266. https://doi.org/10.2307/2326527

Siriopoulos, C., Tziogkidis, P., 2010. How do Greek banking institutions react after significant events?-A DEA approach. Omega 38, 294-308. https://doi.org/10.1016/j.omega.2009.06.001

Tziogkidis, P., Matthews, K., Philippas, D., 2018. The effects of sector reforms on the productivity of Greek banks: a step-by-step analysis of the pre-Euro era. Annals of Operations Research 266, 531-549. https://doi.org/10.1007/s10479-016-2381-3

Weill, L., 2009. Convergence in banking efficiency across European countries. Journal of International Financial Markets, Institutions and Money 19, 818-833. https://doi.org/10.1016/j.intfin.2009.05.002 


\title{
Supplement
}

\section{Multidirectional conditional convergence in European banking}

\author{
Panagiotis Tziogkidis, Dionisis Philippas, Mike G. Tsionas
}

The tables and figures below provide analytical results for each bank and each period considered.

Tables S1-S6 present the results on multidirectional productivity change for each bank and each adjacent period. The tables report productivity change, efficiency change and technical change for each input and output considered.

Figures S1-S18 present the scatterplots for the convergence regressions and associated kernel densities for each adjacent period and are split in three columns. The scatterplots of the first column present on the vertical axis the left-hand side of equations (18), (19) and (20), as per the indicated figure caption, while the horizontal axes include the respective right-hand side. For ease of exposition, we loosely name the vertical axes as log efficiency change for the respective input or output and the horizontal axis as the associated log efficiency. The red line is the OLS line associated with the respective beta absolute convergence regression, while the darker the filling of the dots, the higher the value of the Liquid Assets Ratio that is used to test for conditional convergence. The second column presents the same scatterplots with the only difference being that the colouring of the markers is according to the Capital Adequacy Ratio instead. The third column presents the respective kernel densities and the readers are referred to the notes of Figure 3 for more information.

Tables S7-S12 present the results for beta convergence for each adjacent period. For more information the readers are referred to the notes of Table 3 of the paper. 
Table S1. Malmquist productivity change and decompositions for the period 2011-2012

\begin{tabular}{|c|c|c|c|c|c|c|c|c|c|c|c|c|c|c|c|}
\hline \multirow{2}{*}{$\begin{array}{c}\underline{2011-2012} \\
\text { Bank }\end{array}$} & \multicolumn{5}{|c|}{ Productivity Change } & \multicolumn{5}{|c|}{ Efficiency Change } & \multicolumn{5}{|c|}{ Technical Change } \\
\hline & $\begin{array}{l}\text { Fixed } \\
\text { Assets }\end{array}$ & $\begin{array}{c}\text { Staff } \\
\text { Expenses }\end{array}$ & NPLS & $\begin{array}{c}\text { Net } \\
\text { Loans }\end{array}$ & $\begin{array}{c}\text { Other } \\
\text { Earning } \\
\text { Assets }\end{array}$ & $\begin{array}{l}\text { Fixed } \\
\text { Assets }\end{array}$ & $\begin{array}{c}\text { Staff } \\
\text { Expenses }\end{array}$ & NPLs & $\begin{array}{c}\text { Net } \\
\text { Loans }\end{array}$ & $\begin{array}{l}\text { Other } \\
\text { Earning } \\
\text { Assets }\end{array}$ & $\begin{array}{l}\text { Fixed } \\
\text { Assets }\end{array}$ & $\begin{array}{c}\text { Staff } \\
\text { Expenses }\end{array}$ & NPLS & $\begin{array}{c}\text { Net } \\
\text { Loans }\end{array}$ & $\begin{array}{c}\text { Other } \\
\text { Earning } \\
\text { Assets }\end{array}$ \\
\hline $\begin{array}{l}\text { Bank für Arbeit und Wirtschaft und } \\
\text { Österreichische Postsparkasse } \\
\text { Aktiengesellschaft-BAWAG P.S.K. AG }\end{array}$ & 0.96 & 0.95 & 0.95 & 0.93 & 1.03 & 1.00 & 0.99 & 1.02 & 0.92 & 1.23 & 0.95 & 0.96 & 0.94 & 1.01 & 0.84 \\
\hline $\begin{array}{l}\text { Belfius Banque SA/NV-Belfius Bank } \\
\text { SA/NV }\end{array}$ & 0.89 & 0.94 & 0.93 & 0.93 & 0.87 & 1.03 & 1.00 & 1.00 & 0.95 & 1.02 & 0.87 & 0.94 & 0.92 & 0.98 & 0.86 \\
\hline Banque Degroof Petercam SA & 0.78 & 0.79 & 0.74 & 0.83 & 1.05 & 0.66 & 0.69 & 0.75 & 0.61 & 0.84 & 1.18 & 1.14 & 0.98 & 1.35 & 1.25 \\
\hline $\begin{array}{l}\text { Bank of Cyprus Public Company Limited- } \\
\text { Bank of Cyprus Group }\end{array}$ & 1.19 & 1.19 & 1.20 & 1.07 & 0.81 & 1.08 & 1.09 & 1.08 & 1.26 & 0.95 & 1.11 & 1.09 & 1.11 & 0.85 & 0.86 \\
\hline RCB Bank Ltd & 1.00 & 1.00 & 1.00 & 1.00 & 1.00 & 1.00 & 1.00 & 1.00 & 1.00 & 1.00 & 1.00 & 1.00 & 1.00 & 1.00 & 1.00 \\
\hline $\begin{array}{l}\text { Hellenic Bank Public Company Limited- } \\
\text { Hellenic Bank Group }\end{array}$ & 1.05 & 1.06 & 1.05 & 1.01 & 1.00 & 1.09 & 1.09 & 1.10 & 1.03 & 1.16 & 0.96 & 0.97 & 0.96 & 0.98 & 0.87 \\
\hline Deutsche Bank AG & 1.07 & 1.02 & 1.00 & 0.76 & 1.00 & 1.15 & 1.05 & 1.00 & 0.58 & 1.00 & 0.93 & 0.98 & 1.00 & 1.32 & 1.00 \\
\hline Commerzbank AG & 1.00 & 1.01 & 1.00 & 0.93 & 0.98 & 1.04 & 1.06 & 1.07 & 0.98 & 1.12 & 0.96 & 0.96 & 0.94 & 0.95 & 0.88 \\
\hline SEB AG & 1.00 & 1.00 & 1.00 & 1.00 & 1.00 & 1.00 & 1.00 & 1.00 & 1.00 & 1.00 & 1.00 & 1.00 & 1.00 & 1.00 & 1.00 \\
\hline Swedbank As & 1.16 & 1.21 & 1.20 & 1.15 & 0.82 & 1.09 & 1.15 & 1.12 & 1.40 & 0.89 & 1.07 & 1.05 & 1.08 & 0.82 & 0.91 \\
\hline AS SEB Pank & 0.95 & 0.99 & 0.99 & 1.00 & 0.70 & 0.96 & 0.99 & 0.98 & 1.05 & 1.18 & 0.99 & 1.00 & 1.01 & 0.95 & 0.59 \\
\hline Banco Santand & 1.00 & 1.00 & 0.99 & 0.97 & 1.06 & 1.04 & 1.02 & 1.04 & 0.98 & 1.25 & 0.96 & 0.97 & 0.96 & 0.99 & 0.85 \\
\hline $\begin{array}{l}\text { Banco Bilbao Vizcaya Argentaria SA- } \\
\text { BBVA }\end{array}$ & 0.92 & 0.94 & 0.92 & 0.95 & 1.02 & 1.04 & 1.03 & 1.04 & 0.95 & 1.16 & 0.88 & 0.91 & 0.88 & 1.00 & 0.89 \\
\hline Caixabank, S.A. & 0.95 & 0.96 & 0.95 & 1.09 & 1.26 & 1.10 & 1.08 & 1.10 & 1.03 & 1.37 & 0.87 & 0.89 & 0.86 & 1.05 & 0.92 \\
\hline Banco de Sabadell SA & 0.90 & 0.90 & 0.90 & 1.20 & 1.56 & 1.06 & 1.05 & 1.06 & 1.07 & 1.54 & 0.85 & 0.85 & 0.85 & 1.12 & 1.01 \\
\hline Banco Popular Espanol SA & 0.91 & 0.92 & 0.91 & 1.02 & 1.05 & 1.00 & 0.99 & 1.00 & 0.95 & 1.24 & 0.91 & 0.93 & 0.90 & 1.07 & 0.85 \\
\hline Bankinter SA & 0.97 & 0.97 & 0.96 & 0.98 & 0.90 & 0.99 & 0.98 & 0.97 & 0.94 & 1.12 & 0.97 & 1.00 & 0.98 & 1.04 & 0.81 \\
\hline Ibercaja Banco SA & 1.02 & 1.02 & 1.02 & 0.97 & 1.17 & 1.01 & 1.00 & 1.00 & 1.00 & 1.48 & 1.02 & 1.02 & 1.01 & 0.97 & 0.79 \\
\hline Abanca Corporacion Bancaria SA & 0.97 & 0.97 & 0.97 & 0.69 & 1.37 & 0.92 & 0.90 & 0.93 & 0.73 & 1.82 & 1.05 & 1.08 & 1.04 & 0.93 & 0.75 \\
\hline Nordea Bank Finland Plc & 1.00 & 1.00 & 1.00 & 1.00 & 1.00 & 1.00 & 1.00 & 1.00 & 1.00 & 1.00 & 1.00 & 1.00 & 1.00 & 1.00 & 1.00 \\
\hline Danske Bank Plc & 1.44 & 1.20 & 1.27 & 1.10 & 1.95 & 1.22 & 1.13 & 1.42 & 1.30 & 1.93 & 1.18 & 1.06 & 0.89 & 0.85 & 1.01 \\
\hline BNP Paribas & 0.97 & 0.98 & 0.98 & 0.94 & 0.94 & 1.10 & 1.08 & 1.10 & 1.05 & 1.03 & 0.88 & 0.91 & 0.89 & 0.89 & 0.92 \\
\hline Société Générale SA & 0.97 & 0.98 & 0.98 & 0.93 & 1.05 & 1.11 & 1.10 & 1.13 & 1.08 & 1.10 & 0.87 & 0.89 & 0.87 & 0.86 & 0.95 \\
\hline Banque Fédérative du Crédit Mutuel & 0.94 & 0.95 & 0.94 & 0.96 & 0.99 & 1.08 & 1.05 & 1.08 & 0.99 & 1.12 & 0.87 & 0.90 & 0.87 & 0.97 & 0.88 \\
\hline La Banque Postale & 0.58 & 0.36 & 0.17 & 3.08 & 1.99 & 1.00 & 1.00 & 1.00 & 1.00 & 1.00 & 0.58 & 0.36 & 0.17 & 3.08 & 1.99 \\
\hline HSBC France SA & 1.00 & 1.00 & 1.00 & 1.00 & 1.00 & 1.00 & 1.00 & 1.00 & 1.00 & 1.00 & 1.00 & 1.00 & 1.00 & 1.00 & 1.00 \\
\hline
\end{tabular}




\begin{tabular}{|c|c|c|c|c|c|c|c|c|c|c|c|c|c|c|c|}
\hline RCI Banque SA & 1.00 & 1.00 & 1.00 & 1.00 & 1.00 & 1.00 & 1.00 & 1.00 & 1.00 & 1.00 & 1.00 & 1.00 & 1.00 & 1.00 & 1.00 \\
\hline Piraeus Bank SA & 0.95 & 0.95 & 0.96 & 1.12 & 1.96 & 1.15 & 1.11 & 1.16 & 1.07 & 1.91 & 0.83 & 0.86 & 0.82 & 1.05 & 1.03 \\
\hline National Bank of Greece SA & 1.05 & 1.06 & 1.05 & 1.01 & 1.06 & 1.03 & 1.04 & 1.03 & 1.08 & 1.15 & 1.02 & 1.02 & 1.01 & 0.93 & 0.92 \\
\hline Alpha Bank AE & 1.01 & 1.00 & 1.00 & 0.93 & 1.43 & 1.00 & 0.99 & 1.00 & 0.94 & 1.67 & 1.00 & 1.02 & 1.00 & 0.99 & 0.85 \\
\hline Eurobank Ergasias SA & 1.06 & 1.07 & 1.06 & 0.96 & 0.89 & 1.02 & 1.02 & 1.02 & 0.99 & 1.04 & 1.05 & 1.05 & 1.05 & 0.97 & 0.86 \\
\hline $\begin{array}{l}\text { Bank of Ireland-Governor and Company of } \\
\text { the Bank of Ireland }\end{array}$ & 0.94 & 0.94 & 0.92 & 0.91 & 0.94 & 0.95 & 0.94 & 0.95 & 0.99 & 1.09 & 0.99 & 1.00 & 0.97 & 0.93 & 0.87 \\
\hline Allied Irish Banks plc & 0.94 & 0.92 & 0.91 & 0.86 & 0.83 & 0.98 & 0.95 & 1.00 & 0.94 & 0.97 & 0.95 & 0.97 & 0.91 & 0.92 & 0.86 \\
\hline Citibank Europe Plc & 1.30 & 0.83 & 1.42 & 1.41 & 0.28 & 1.00 & 1.00 & 1.00 & 1.00 & 1.00 & 1.30 & 0.83 & 1.42 & 1.41 & 0.28 \\
\hline Ulster Bank Ireland DAC & 0.94 & 0.94 & 0.90 & 0.90 & 0.95 & 0.99 & 0.95 & 0.99 & 0.87 & 1.19 & 0.95 & 0.98 & 0.91 & 1.03 & 0.80 \\
\hline UniCredit SpA & 0.99 & 1.00 & 0.99 & 0.98 & 1.01 & 1.05 & 1.04 & 1.05 & 1.00 & 1.14 & 0.94 & 0.96 & 0.94 & 0.97 & 0.88 \\
\hline Intesa Sanpaolo & 0.99 & 1.01 & 0.99 & 0.99 & 1.12 & 1.07 & 1.07 & 1.06 & 1.05 & 1.23 & 0.93 & 0.94 & 0.93 & 0.94 & 0.91 \\
\hline $\begin{array}{l}\text { Banca Monte dei Paschi di Siena SpA- } \\
\text { Gruppo Monte dei Paschi di Siena }\end{array}$ & 0.99 & 0.99 & 0.99 & 0.97 & 0.82 & 1.05 & 1.02 & 1.05 & 1.00 & 0.97 & 0.95 & 0.97 & 0.94 & 0.97 & 0.85 \\
\hline $\begin{array}{l}\text { Mediobanca SpA-MEDIOBANCA - Banca } \\
\text { di Credito Finanziario Società per Azioni }\end{array}$ & 0.81 & 0.90 & 0.92 & 0.97 & 0.88 & 1.06 & 1.04 & 1.02 & 1.03 & 0.96 & 0.77 & 0.87 & 0.91 & 0.94 & 0.91 \\
\hline Banca Carige SpA & 1.00 & 1.00 & 0.99 & 1.08 & 1.06 & 1.06 & 1.06 & 1.05 & 1.09 & 1.23 & 0.94 & 0.95 & 0.95 & 0.99 & 0.87 \\
\hline Swedbank AB & 1.07 & 1.06 & 1.07 & 1.06 & 1.19 & 1.03 & 1.04 & 1.04 & 1.14 & 1.38 & 1.03 & 1.01 & 1.03 & 0.93 & 0.87 \\
\hline AB SEB Bankas & 1.15 & 1.07 & 1.17 & 1.05 & 1.15 & 1.12 & 1.07 & 1.12 & 1.22 & 1.25 & 1.03 & 0.99 & 1.05 & 0.86 & 0.92 \\
\hline Luminor Bank AB & 0.90 & 0.91 & 0.89 & 0.95 & 1.20 & 1.00 & 0.97 & 1.00 & 0.90 & 1.37 & 0.91 & 0.94 & 0.90 & 1.05 & 0.88 \\
\hline KBL European Private Bankers SA & 0.71 & 0.70 & 0.89 & 0.66 & 0.86 & 0.86 & 0.85 & 0.89 & 0.62 & 0.95 & 0.83 & 0.83 & 1.01 & 1.07 & 0.91 \\
\hline Swedbank AS & 1.00 & 1.01 & 1.01 & 0.99 & 0.80 & 1.12 & 1.08 & 1.14 & 0.99 & 0.84 & 0.90 & 0.94 & 0.88 & 1.00 & 0.95 \\
\hline ABLV Bank AS & 0.99 & 1.00 & 1.01 & 1.06 & 1.18 & 1.03 & 1.06 & 1.06 & 1.11 & 1.30 & 0.96 & 0.95 & 0.95 & 0.96 & 0.91 \\
\hline SEB banka AS & 1.01 & 0.99 & 0.99 & 1.00 & 1.19 & 1.09 & 1.04 & 1.10 & 0.96 & 1.36 & 0.92 & 0.95 & 0.90 & 1.04 & 0.87 \\
\hline Bank of Valletta Plc & 0.98 & 0.98 & 0.99 & 1.00 & 1.01 & 1.01 & 1.01 & 1.02 & 1.01 & 1.23 & 0.97 & 0.97 & 0.97 & 1.00 & 0.83 \\
\hline HSBC Bank Malta Plc & 1.04 & 1.04 & 1.04 & 1.04 & 1.13 & 1.04 & 1.04 & 1.04 & 1.09 & 1.32 & 1.00 & 1.00 & 1.00 & 0.95 & 0.86 \\
\hline ING Bank NV & 1.05 & 1.05 & 1.05 & 1.00 & 0.99 & 1.04 & 1.04 & 1.05 & 1.08 & 1.10 & 1.01 & 1.01 & 1.00 & 0.93 & 0.90 \\
\hline ABN AMRO Bank NV & 1.03 & 1.02 & 1.03 & 1.07 & 0.82 & 1.06 & 1.04 & 1.05 & 1.08 & 0.95 & 0.97 & 0.98 & 0.98 & 0.99 & 0.86 \\
\hline De Volksbank N.V. & 1.15 & 0.97 & 0.84 & 0.97 & 1.17 & 1.11 & 1.05 & 1.48 & 1.06 & 2.44 & 1.03 & 0.92 & 0.57 & 0.91 & 0.48 \\
\hline Caixa Geral de Depositos & 1.05 & 1.04 & 1.04 & 1.00 & 1.07 & 1.05 & 1.04 & 1.04 & 1.05 & 1.27 & 1.00 & 1.00 & 0.99 & 0.96 & 0.84 \\
\hline $\begin{array}{l}\text { Banco Comercial Português, SA- } \\
\text { Millennium bcp }\end{array}$ & 1.06 & 1.07 & 1.06 & 0.98 & 1.11 & 1.06 & 1.06 & 1.07 & 1.01 & 1.27 & 1.00 & 1.01 & 0.99 & 0.97 & 0.88 \\
\hline NLB dd-Nova Ljubljanska Banka d.d. & 1.04 & 1.03 & 1.03 & 0.93 & 0.84 & 1.02 & 1.00 & 1.03 & 0.97 & 1.00 & 1.01 & 1.03 & 1.01 & 0.96 & 0.84 \\
\hline Nova Kreditna Banka Maribor d.d. & 1.01 & 1.01 & 1.01 & 0.91 & 0.92 & 1.02 & 1.01 & 1.03 & 0.94 & 1.12 & 0.98 & 1.00 & 0.98 & 0.97 & 0.82 \\
\hline Abanka d.d & 0.98 & 0.99 & 0.98 & 0.87 & 0.76 & 0.98 & 0.96 & 0.98 & 0.91 & 0.98 & 1.00 & 1.03 & 0.99 & 0.96 & 0.77 \\
\hline
\end{tabular}


Table S2. Malmquist productivity change and decompositions for the period 2012-2013

\begin{tabular}{|c|c|c|c|c|c|c|c|c|c|c|c|c|c|c|c|}
\hline \multirow{2}{*}{$\begin{array}{c}\underline{2012-2013} \\
\text { Bank }\end{array}$} & \multicolumn{5}{|c|}{ Productivity Change } & \multicolumn{5}{|c|}{ Efficiency Change } & \multicolumn{5}{|c|}{ Technical Change } \\
\hline & $\begin{array}{l}\text { Fixed } \\
\text { Assets }\end{array}$ & $\begin{array}{c}\text { Staff } \\
\text { Expenses }\end{array}$ & NPLs & $\begin{array}{c}\text { Net } \\
\text { Loans }\end{array}$ & $\begin{array}{c}\text { Other } \\
\text { Earning } \\
\text { Assets }\end{array}$ & $\begin{array}{l}\text { Fixed } \\
\text { Assets }\end{array}$ & $\begin{array}{c}\text { Staff } \\
\text { Expenses }\end{array}$ & NPLs & $\begin{array}{l}\text { Net } \\
\text { Loans }\end{array}$ & $\begin{array}{c}\text { Other } \\
\text { Earning } \\
\text { Assets }\end{array}$ & $\begin{array}{l}\text { Fixed } \\
\text { Assets }\end{array}$ & $\begin{array}{c}\text { Staff } \\
\text { Expenses }\end{array}$ & NPLs & $\begin{array}{c}\text { Net } \\
\text { Loans }\end{array}$ & $\begin{array}{c}\text { Other } \\
\text { Earning } \\
\text { Assets }\end{array}$ \\
\hline $\begin{array}{l}\text { Bank für Arbeit und Wirtschaft und } \\
\text { Österreichische Postsparkasse } \\
\text { Aktiengesellschaft-BAWAG P.S.K. AG }\end{array}$ & 1.21 & 1.14 & 1.19 & 1.07 & 0.98 & 1.05 & 1.07 & 1.11 & 1.58 & 1.12 & 1.15 & 1.07 & 1.07 & 0.68 & 0.88 \\
\hline $\begin{array}{l}\text { Belfius Banque SA/NV-Belfius Bank } \\
\text { SA/NV }\end{array}$ & 1.44 & 1.15 & 1.24 & 1.06 & 0.96 & 1.18 & 1.15 & 1.19 & 1.38 & 1.28 & 1.22 & 0.99 & 1.04 & 0.77 & 0.75 \\
\hline Banque Degroof Petercam SA & 0.84 & 0.86 & 0.84 & 0.79 & 0.94 & 1.37 & 1.35 & 1.27 & 2.63 & 1.18 & 0.62 & 0.64 & 0.66 & 0.30 & 0.79 \\
\hline $\begin{array}{l}\text { Bank of Cyprus Public Company Limited- } \\
\text { Bank of Cyprus Group }\end{array}$ & 1.03 & 0.98 & 1.03 & 0.94 & 1.33 & 0.89 & 0.90 & 0.89 & 1.12 & 1.92 & 1.16 & 1.08 & 1.15 & 0.84 & 0.69 \\
\hline RCB Bank Ltd & 1.00 & 0.21 & 0.04 & 1.00 & 1.00 & 1.00 & 1.00 & 1.00 & 1.00 & 1.00 & 1.00 & 0.21 & 0.04 & 1.00 & 1.00 \\
\hline $\begin{array}{l}\text { Hellenic Bank Public Company Limited- } \\
\text { Hellenic Bank Group }\end{array}$ & 1.12 & 1.12 & 1.12 & 0.86 & 0.70 & 0.91 & 0.92 & 0.91 & 1.34 & 0.85 & 1.24 & 1.21 & 1.22 & 0.65 & 0.82 \\
\hline Deutsche Bank AG & 0.97 & 0.97 & 1.00 & 1.46 & 1.00 & 0.94 & 0.94 & 1.00 & 2.14 & 1.00 & 1.03 & 1.03 & 1.00 & 0.68 & 1.00 \\
\hline Commerzbank AG & 0.96 & 0.99 & 1.00 & 0.91 & 0.88 & 0.98 & 0.99 & 1.05 & 1.22 & 1.01 & 0.99 & 1.00 & 0.95 & 0.74 & 0.86 \\
\hline SEB AG & 1.00 & 1.00 & 1.00 & 1.00 & 1.00 & 1.00 & 1.00 & 1.00 & 1.00 & 1.00 & 1.00 & 1.00 & 1.00 & 1.00 & 1.00 \\
\hline Swedbank As & 1.00 & 1.00 & 1.04 & 1.01 & 0.98 & 0.95 & 1.08 & 1.10 & 1.31 & 1.39 & 1.04 & 0.92 & 0.95 & 0.78 & 0.71 \\
\hline AS SEB Pank & 1.22 & 1.12 & 1.30 & 1.12 & 2.07 & 1.28 & 1.26 & 1.59 & 1.37 & 4.11 & 0.95 & 0.89 & 0.82 & 0.82 & 0.50 \\
\hline Banco Santander SA & 0.99 & 1.00 & 0.99 & 0.95 & 0.84 & 1.03 & 1.02 & 1.08 & 1.34 & 1.02 & 0.96 & 0.98 & 0.91 & 0.71 & 0.83 \\
\hline $\begin{array}{l}\text { Banco Bilbao Vizcaya Argentaria SA- } \\
\text { BBVA }\end{array}$ & 0.97 & 0.98 & 0.96 & 0.92 & 0.90 & 1.02 & 1.01 & 1.06 & 1.23 & 1.04 & 0.95 & 0.97 & 0.90 & 0.74 & 0.87 \\
\hline Caixabank, S.A. & 0.81 & 0.82 & 0.80 & 0.82 & 0.84 & 0.96 & 0.92 & 0.99 & 1.05 & 0.99 & 0.84 & 0.89 & 0.81 & 0.78 & 0.85 \\
\hline Banco de Sabadell SA & 0.91 & 0.93 & 0.91 & 1.00 & 0.71 & 0.97 & 0.98 & 0.98 & 1.26 & 0.77 & 0.94 & 0.95 & 0.92 & 0.79 & 0.93 \\
\hline Banco Popular Espanol SA & 0.95 & 0.97 & 0.94 & 0.98 & 0.81 & 1.00 & 1.01 & 1.02 & 1.29 & 0.83 & 0.95 & 0.96 & 0.92 & 0.76 & 0.97 \\
\hline Bankinter SA & 0.91 & 0.95 & 0.91 & 0.96 & 0.76 & 1.09 & 1.09 & 1.15 & 1.25 & 0.90 & 0.84 & 0.87 & 0.79 & 0.77 & 0.85 \\
\hline Kutxabank SA & 1.02 & 1.02 & 1.02 & 0.96 & 0.89 & 0.96 & 0.98 & 0.98 & 1.30 & 1.00 & 1.06 & 1.04 & 1.03 & 0.74 & 0.89 \\
\hline Ibercaja Banco SA & 0.89 & 0.92 & 0.88 & 1.06 & 1.41 & 0.95 & 1.00 & 0.98 & 1.28 & 1.31 & 0.94 & 0.91 & 0.90 & 0.83 & 1.08 \\
\hline Abanca Corporacion Bancaria SA & 1.39 & 1.36 & 1.37 & 1.07 & 1.22 & 1.05 & 1.11 & 1.06 & 1.74 & 1.38 & 1.33 & 1.22 & 1.29 & 0.62 & 0.89 \\
\hline Nordea Bank Finland Plc & 1.31 & 1.41 & 0.68 & 0.94 & 1.00 & 1.00 & 1.00 & 1.00 & 1.00 & 1.00 & 1.31 & 1.41 & 0.68 & 0.94 & 1.00 \\
\hline Danske Bank Plc & 1.15 & 1.22 & 1.09 & 1.01 & 1.25 & 1.05 & 1.15 & 1.10 & 1.02 & 1.56 & 1.10 & 1.06 & 0.99 & 0.99 & 0.80 \\
\hline BNP Paribas & 0.96 & 0.98 & 0.97 & 0.95 & 0.93 & 0.99 & 1.00 & 1.02 & 1.25 & 1.04 & 0.97 & 0.98 & 0.95 & 0.76 & 0.90 \\
\hline Société Générale SA & 0.97 & 0.99 & 0.97 & 0.96 & 0.97 & 1.00 & 1.01 & 1.03 & 1.27 & 1.07 & 0.97 & 0.97 & 0.95 & 0.75 & 0.91 \\
\hline Banque Fédérative du Crédit Mutuel & 0.96 & 0.97 & 0.96 & 0.99 & 0.96 & 1.01 & 1.02 & 1.05 & 1.27 & 1.06 & 0.95 & 0.95 & 0.91 & 0.78 & 0.91 \\
\hline La Banque Postale & 0.17 & 0.29 & 0.14 & 3.56 & 0.61 & 1.00 & 1.00 & 1.00 & 1.00 & 1.00 & 0.17 & 0.29 & 0.14 & 3.56 & 0.61 \\
\hline
\end{tabular}


HSBC France SA

RCI Banque SA

Piraeus Bank SA

National Bank of Greece SA

Alpha Bank AE

Eurobank Ergasias SA

Bank of Ireland-Governor and Company of

the Bank of Ireland

Allied Irish Banks plc

Citibank Europe Plc

Ulster Bank Ireland DAC

UniCredit SpA

Intesa Sanpaolo

Banca Monte dei Paschi di Siena SpA-

Gruppo Monte dei Paschi di Siena

Mediobanca SpA-MEDIOBANCA - Banca

di Credito Finanziario Società per Azioni

Banca Carige SpA

Swedbank AB

AB SEB Bankas

Luminor Bank AB

Banque Internationale à Luxembourg SA

KBL European Private Bankers SA

Swedbank AS

ABLV Bank AS

SEB banka AS

Bank of Valletta Plc

HSBC Bank Malta Plc

ING Bank NV

ABN AMRO Bank NV

De Volksbank N.V.

Caixa Geral de Depositos

Banco Comercial Português, SA-

Millennium bcp

NLB dd-Nova Ljubljanska Banka d.d.

\begin{tabular}{|c|c|c|c|c|c|c|c|c|c|c|c|c|c|c|}
\hline 0.20 & 2.54 & 0.66 & 1.12 & 1.00 & 1.00 & 1.00 & 1.00 & 1.00 & 1.00 & 0.20 & 2.54 & 0.66 & 1.12 & 1.00 \\
\hline 1.00 & 1.00 & 1.00 & 1.00 & 1.00 & 1.00 & 1.00 & 1.00 & 1.00 & 1.00 & 1.00 & 1.00 & 1.00 & 1.00 & 1.00 \\
\hline 0.69 & 0.71 & 0.68 & 0.98 & 0.74 & 0.92 & 0.89 & 0.92 & 1.04 & 0.81 & 0.75 & 0.80 & 0.74 & 0.94 & 0.91 \\
\hline 0.94 & 0.94 & 0.94 & 0.94 & 1.14 & 1.02 & 1.01 & 1.04 & 1.20 & 1.31 & 0.92 & 0.93 & 0.90 & 0.78 & 0.87 \\
\hline 0.88 & 0.89 & 0.88 & 1.09 & 1.01 & 1.10 & 1.07 & 1.11 & 1.35 & 1.05 & 0.81 & 0.83 & 0.79 & 0.81 & 0.97 \\
\hline 0.98 & 0.98 & 0.97 & 1.02 & 1.29 & 1.09 & 1.08 & 1.10 & 1.35 & 1.36 & 0.90 & 0.91 & 0.88 & 0.76 & 0.95 \\
\hline 1.24 & 1.26 & 1.31 & 1.06 & 1.21 & 1.05 & 1.13 & 1.09 & 1.38 & 1.45 & 1.18 & 1.11 & 1.20 & 0.77 & 0.83 \\
\hline 1.22 & 1.24 & 1.26 & 1.05 & 1.24 & 1.06 & 1.13 & 1.08 & 1.44 & 1.40 & 1.15 & 1.10 & 1.16 & 0.73 & 0.89 \\
\hline 1.00 & 1.00 & 1.00 & 1.00 & 1.00 & 1.00 & 1.00 & 1.00 & 1.00 & 1.00 & 1.00 & 1.00 & 1.00 & 1.00 & 1.00 \\
\hline 0.97 & 1.03 & 1.00 & 0.90 & 1.18 & 0.98 & 1.05 & 1.04 & 1.26 & 1.47 & 0.99 & 0.98 & 0.96 & 0.71 & 0.80 \\
\hline 0.98 & 0.98 & 0.97 & 0.92 & 0.89 & 1.02 & 1.01 & 1.04 & 1.21 & 1.04 & 0.96 & 0.97 & 0.93 & 0.76 & 0.86 \\
\hline 0.98 & 1.00 & 0.97 & 0.93 & 0.95 & 0.99 & 1.04 & 1.00 & 1.19 & 1.09 & 0.99 & 0.97 & 0.97 & 0.78 & 0.87 \\
\hline 1.02 & 1.08 & 1.05 & 0.97 & 0.95 & 0.98 & 1.09 & 1.02 & 1.31 & 1.10 & 1.04 & 1.00 & 1.02 & 0.74 & 0.86 \\
\hline 0.99 & 1.00 & 0.96 & 0.93 & 0.99 & 0.98 & 1.08 & 1.07 & 1.14 & 1.17 & 1.01 & 0.93 & 0.90 & 0.82 & 0.85 \\
\hline 1.04 & 1.02 & 1.02 & 0.91 & 0.96 & 1.00 & 1.03 & 1.01 & 1.16 & 1.19 & 1.03 & 0.99 & 1.01 & 0.79 & 0.81 \\
\hline 0.98 & 0.98 & 0.98 & 1.01 & 0.63 & 0.95 & 0.96 & 0.97 & 1.23 & 0.65 & 1.03 & 1.02 & 1.01 & 0.82 & 0.98 \\
\hline 0.98 & 1.01 & 1.00 & 0.98 & 1.17 & 0.97 & 0.99 & 1.03 & 0.99 & 1.37 & 1.00 & 1.02 & 0.97 & 0.99 & 0.86 \\
\hline 0.97 & 0.97 & 0.97 & 1.01 & 0.97 & 1.07 & 1.08 & 1.09 & 1.34 & 1.22 & 0.91 & 0.90 & 0.89 & 0.75 & 0.79 \\
\hline 0.97 & 0.97 & 0.96 & 1.01 & 0.97 & 1.07 & 1.09 & 1.18 & 1.58 & 1.16 & 0.90 & 0.89 & 0.82 & 0.64 & 0.84 \\
\hline 0.70 & 0.70 & 0.97 & 0.46 & 0.96 & 1.22 & 1.22 & 1.21 & 4.30 & 1.12 & 0.58 & 0.58 & 0.80 & 0.11 & 0.86 \\
\hline 0.99 & 0.99 & 1.00 & 0.95 & 0.45 & 0.98 & 1.03 & 1.06 & 1.28 & 0.47 & 1.01 & 0.96 & 0.95 & 0.74 & 0.97 \\
\hline 0.91 & 0.91 & 0.93 & 0.95 & 1.00 & 0.89 & 0.91 & 0.94 & 1.21 & 1.12 & 1.02 & 0.99 & 1.00 & 0.78 & 0.89 \\
\hline 1.11 & 1.05 & 1.21 & 1.06 & 1.07 & 0.99 & 1.15 & 1.17 & 1.43 & 1.37 & 1.12 & 0.91 & 1.03 & 0.74 & 0.78 \\
\hline 1.00 & 1.00 & 1.00 & 0.99 & 1.02 & 0.95 & 0.99 & 1.02 & 1.38 & 1.12 & 1.05 & 1.01 & 0.98 & 0.72 & 0.91 \\
\hline 1.03 & 1.04 & 1.01 & 1.02 & 0.98 & 0.97 & 1.00 & 1.00 & 1.43 & 1.08 & 1.06 & 1.04 & 1.02 & 0.71 & 0.92 \\
\hline 0.98 & 0.99 & 0.97 & 0.95 & 0.97 & 0.99 & 1.06 & 1.07 & 1.28 & 1.12 & 0.99 & 0.94 & 0.91 & 0.74 & 0.87 \\
\hline 1.02 & 1.02 & 1.02 & 0.97 & 1.03 & 1.02 & 1.10 & 1.11 & 1.34 & 1.18 & 1.00 & 0.93 & 0.92 & 0.72 & 0.87 \\
\hline 1.00 & 1.00 & 1.00 & 1.00 & 1.00 & 1.00 & 1.00 & 1.00 & 1.00 & 1.00 & 1.00 & 1.00 & 1.00 & 1.00 & 1.00 \\
\hline 1.13 & 1.08 & 1.18 & 1.01 & 0.82 & 0.95 & 1.07 & 1.09 & 1.45 & 1.19 & 1.20 & 1.01 & 1.09 & 0.69 & 0.69 \\
\hline 1.01 & 1.02 & 1.01 & 0.94 & 0.94 & 1.01 & 1.02 & 1.07 & 1.33 & 1.11 & 0.99 & 1.00 & 0.94 & 0.71 & 0.84 \\
\hline 1.06 & 1.05 & 1.06 & 0.82 & 1.26 & 1.03 & 1.02 & 1.05 & 1.17 & 1.54 & 1.02 & 1.04 & 1.01 & 0.70 & 0.82 \\
\hline
\end{tabular}




\begin{tabular}{|c|c|c|c|c|c|c|c|c|c|c|c|c|c|c|c|}
\hline Nova Kreditna Banka Maribor d.d. & 1.00 & 1.00 & 1.00 & 0.72 & 1.39 & 0.96 & 0.95 & 0.98 & 1.04 & 1.70 & 1.04 & 1.05 & 1.03 & 0.69 & 0.82 \\
\hline Abanka d.d & 0.98 & 0.99 & 0.98 & 0.78 & 0.99 & 0.95 & 0.94 & 0.96 & 1.14 & 1.21 & 1.03 & 1.05 & 1.02 & 0.69 & 0.82 \\
\hline Vseobecna Uverova Banka a.s. & 0.95 & 0.95 & 0.95 & 0.97 & 1.03 & 0.98 & 0.98 & 1.03 & 1.30 & 1.18 & 0.97 & 0.97 & 0.93 & 0.74 & 0.87 \\
\hline
\end{tabular}

Table S3. Malmquist productivity change and decompositions for the period 2013-2014

\section{$\underline{2013-2014}$}

\section{Productivity Change}

Stafl

Assets Expenses

\section{Bank}

Bank für Arbeit und Wirtschaft und

Österreichische Postsparkasse

Aktiengesellschaft-BAWAG P.S.K. AG

Sberbank Europe AG

Belfius Banque SA/NV-Belfius Bank

SA/NV

Banque Degroof Petercam SA

Bank of Cyprus Public Company Limited-

Bank of Cyprus Group

RCB Bank Ltd

Hellenic Bank Public Company Limited-

Hellenic Bank Group

Deutsche Bank AG

Commerzbank AG

SEB AG

Swedbank As

\section{AS SEB Pank}

Banco Santander SA

Banco Bilbao Vizcaya Argentaria SA-

BBVA

Caixabank, S.A.

Banco de Sabadell SA

Banco Popular Espanol SA

Bankinter SA

Kutxabank SA

Ibercaja Banco SA

Abanca Corporacion Bancaria SA

\begin{tabular}{|c|c|c|c|c|c|c|c|c|c|c|c|c|c|c|}
\hline 1.08 & 1.08 & 1.09 & 1.06 & 0.93 & 1.04 & 1.04 & 1.02 & 1.08 & 0.74 & 1.04 & 1.03 & 1.07 & 0.98 & 1.25 \\
\hline 0.97 & 0.95 & 0.98 & 1.12 & 1.09 & 0.93 & 0.99 & 0.92 & 1.02 & 1.06 & 1.04 & 0.96 & 1.06 & 1.10 & 1.03 \\
\hline 0.79 & 0.94 & 0.90 & 0.97 & 0.96 & 0.92 & 0.94 & 0.92 & 0.93 & 0.78 & 0.86 & 1.00 & 0.98 & 1.05 & 1.23 \\
\hline 1.05 & 1.04 & 1.04 & 0.97 & 1.11 & 0.97 & 0.98 & 0.84 & 0.78 & 0.86 & 1.08 & 1.06 & 1.25 & 1.24 & 1.29 \\
\hline 1.33 & 1.30 & 1.33 & 1.03 & 1.23 & 1.06 & 1.11 & 1.05 & 1.11 & 1.15 & 1.25 & 1.16 & 1.26 & 0.93 & 1.07 \\
\hline 1.00 & 1.00 & 1.00 & 1.00 & 1.00 & 1.00 & 1.00 & 1.00 & 1.00 & 1.00 & 1.00 & 1.00 & 1.00 & 1.00 & 1.00 \\
\hline 1.04 & 1.05 & 1.04 & 0.95 & 1.24 & 1.06 & 1.08 & 1.05 & 0.99 & 1.02 & 0.98 & 0.97 & 0.99 & 0.96 & 1.22 \\
\hline 0.88 & 0.93 & 0.93 & 0.86 & 0.94 & 0.77 & 0.86 & 0.86 & 0.74 & 0.88 & 1.14 & 1.08 & 1.08 & 1.16 & 1.07 \\
\hline 1.01 & 1.01 & 1.04 & 0.98 & 1.06 & 1.00 & 1.02 & 0.98 & 0.94 & 0.98 & 1.01 & 0.99 & 1.05 & 1.05 & 1.08 \\
\hline 1.00 & 1.00 & 1.00 & 1.00 & 1.00 & 1.00 & 1.00 & 1.00 & 1.00 & 1.00 & 1.00 & 1.00 & 1.00 & 1.00 & 1.00 \\
\hline 1.02 & 1.01 & 1.02 & 1.01 & 0.80 & 1.07 & 1.00 & 1.05 & 0.99 & 0.64 & 0.95 & 1.01 & 0.97 & 1.03 & 1.26 \\
\hline 0.88 & 0.95 & 0.99 & 0.99 & 0.37 & 0.87 & 0.94 & 0.95 & 0.95 & 0.27 & 1.01 & 1.01 & 1.04 & 1.04 & 1.36 \\
\hline 1.00 & 1.00 & 1.01 & 1.07 & 1.19 & 1.00 & 1.05 & 0.99 & 1.00 & 1.05 & 1.00 & 0.96 & 1.02 & 1.08 & 1.13 \\
\hline 1.01 & 1.02 & 1.02 & 1.04 & 1.17 & 1.00 & 1.04 & 0.98 & 0.98 & 1.05 & 1.02 & 0.98 & 1.04 & 1.06 & 1.11 \\
\hline 1.16 & 1.15 & 1.16 & 1.06 & 1.21 & 1.03 & 1.09 & 1.03 & 1.10 & 1.04 & 1.12 & 1.05 & 1.13 & 0.96 & 1.17 \\
\hline 0.97 & 0.97 & 0.98 & 0.97 & 1.04 & 1.01 & 1.03 & 1.02 & 0.94 & 0.95 & 0.95 & 0.95 & 0.95 & 1.03 & 1.09 \\
\hline 1.05 & 1.02 & 1.05 & 0.98 & 1.45 & 1.00 & 1.04 & 1.00 & 0.97 & 1.37 & 1.05 & 0.98 & 1.05 & 1.01 & 1.05 \\
\hline 1.00 & 0.99 & 1.00 & 1.01 & 1.10 & 1.00 & 1.02 & 1.00 & 0.97 & 1.00 & 1.00 & 0.98 & 1.00 & 1.05 & 1.10 \\
\hline 1.05 & 1.04 & 1.05 & 0.99 & 1.16 & 1.05 & 1.07 & 1.05 & 1.00 & 1.03 & 1.00 & 0.98 & 1.00 & 0.99 & 1.13 \\
\hline 0.84 & 0.86 & 0.84 & 0.87 & 0.88 & 0.99 & 0.95 & 0.97 & 0.81 & 0.84 & 0.85 & 0.90 & 0.87 & 1.08 & 1.04 \\
\hline 1.09 & 1.09 & 1.10 & 1.08 & 1.13 & 1.06 & 1.11 & 1.06 & 1.13 & 1.01 & 1.03 & 0.99 & 1.04 & 0.95 & 1.12 \\
\hline
\end{tabular}

\section{Technical Change}

\section{Efficiency Change}

Other

Other
Earning

Effiency Change

Earning

Fixed Staff Net $\begin{gathered}\text { Other } \\ \text { Earning }\end{gathered}$

0.87 


\begin{tabular}{|c|c|c|c|c|c|c|c|c|c|c|c|c|c|c|c|}
\hline Nordea Bank Finland Plc & 1.41 & 0.96 & 2.12 & 0.81 & 1.00 & 1.00 & 1.00 & 1.00 & 1.00 & 1.00 & 1.41 & 0.96 & 2.12 & 0.81 & 1.00 \\
\hline Danske Bank Plc & 1.00 & 0.98 & 0.91 & 1.00 & 0.88 & 0.99 & 0.95 & 0.83 & 1.00 & 0.77 & 1.00 & 1.02 & 1.10 & 1.00 & 1.14 \\
\hline BNP Paribas & 0.85 & 0.90 & 0.88 & 0.96 & 1.03 & 0.85 & 0.92 & 0.83 & 0.95 & 0.96 & 1.01 & 0.98 & 1.06 & 1.01 & 1.08 \\
\hline Société Générale SA & 0.97 & 0.98 & 0.99 & 1.01 & 1.06 & 0.84 & 0.90 & 0.84 & 1.02 & 1.00 & 1.16 & 1.09 & 1.18 & 0.99 & 1.06 \\
\hline Banque Fédérative du Crédit Mutuel & 1.02 & 1.01 & 1.02 & 1.05 & 1.05 & 0.94 & 0.99 & 0.91 & 1.02 & 0.97 & 1.08 & 1.02 & 1.12 & 1.03 & 1.09 \\
\hline La Banque Postale & 1.87 & 0.47 & 0.32 & 2.11 & 1.34 & 1.00 & 1.00 & 1.00 & 1.00 & 1.00 & 1.87 & 0.47 & 0.32 & 2.11 & 1.34 \\
\hline HSBC France SA & 0.52 & 0.86 & 1.41 & 1.27 & 0.85 & 1.00 & 1.00 & 1.00 & 1.00 & 1.00 & 0.52 & 0.86 & 1.41 & 1.27 & 0.85 \\
\hline RCI Banque SA & 1.91 & 1.00 & 2.50 & 1.00 & 1.00 & 1.00 & 1.00 & 1.00 & 1.00 & 1.00 & 1.91 & 1.00 & 2.50 & 1.00 & 1.00 \\
\hline Piraeus Bank SA & 1.05 & 1.05 & 1.05 & 0.97 & 1.07 & 1.02 & 1.05 & 1.02 & 0.97 & 0.94 & 1.03 & 1.00 & 1.03 & 1.00 & 1.14 \\
\hline National Bank of Greece SA & 1.15 & 1.15 & 1.15 & 1.11 & 1.23 & 1.04 & 1.09 & 1.03 & 1.11 & 1.10 & 1.11 & 1.05 & 1.12 & 1.00 & 1.12 \\
\hline Alpha Bank AE & 0.99 & 1.00 & 0.99 & 0.97 & 1.00 & 1.01 & 1.03 & 1.00 & 0.93 & 0.91 & 0.99 & 0.97 & 0.99 & 1.04 & 1.11 \\
\hline Eurobank Ergasias SA & 1.00 & 1.00 & 0.99 & 0.95 & 1.02 & 1.00 & 1.02 & 1.00 & 0.93 & 0.92 & 0.99 & 0.98 & 0.99 & 1.02 & 1.11 \\
\hline $\begin{array}{l}\text { Bank of Ireland-Governor and Company of } \\
\text { the Bank of Ireland }\end{array}$ & 0.83 & 0.85 & 0.80 & 0.91 & 0.77 & 0.95 & 0.94 & 0.97 & 0.89 & 0.66 & 0.87 & 0.90 & 0.83 & 1.02 & 1.17 \\
\hline Allied Irish Banks plc & 0.92 & 0.93 & 0.91 & 0.94 & 0.79 & 0.95 & 0.97 & 0.96 & 0.93 & 0.70 & 0.97 & 0.96 & 0.94 & 1.01 & 1.13 \\
\hline Citibank Europe Plc & 1.23 & 2.22 & 12.95 & 1.00 & 0.47 & 1.00 & 1.00 & 1.00 & 1.00 & 1.00 & 1.23 & 2.22 & 12.95 & 1.00 & 0.47 \\
\hline Ulster Bank Ireland DAC & 0.98 & 1.00 & 0.98 & 0.95 & 1.09 & 1.01 & 1.01 & 1.02 & 0.94 & 0.95 & 0.97 & 0.99 & 0.96 & 1.01 & 1.14 \\
\hline UniCredit SpA & 1.06 & 1.06 & 1.06 & 0.99 & 1.18 & 0.97 & 1.01 & 0.95 & 0.98 & 1.06 & 1.10 & 1.05 & 1.11 & 1.01 & 1.11 \\
\hline Intesa Sanpaolo & 0.98 & 0.97 & 0.97 & 0.98 & 1.06 & 0.91 & 0.95 & 0.90 & 0.98 & 0.98 & 1.07 & 1.03 & 1.08 & 1.00 & 1.08 \\
\hline $\begin{array}{l}\text { Banca Monte dei Paschi di Siena SpA- } \\
\text { Gruppo Monte dei Paschi di Siena }\end{array}$ & 0.87 & 0.89 & 0.86 & 0.88 & 0.75 & 0.90 & 0.90 & 0.90 & 0.82 & 0.68 & 0.96 & 0.99 & 0.96 & 1.07 & 1.11 \\
\hline $\begin{array}{l}\text { Mediobanca SpA-MEDIOBANCA - Banca } \\
\text { di Credito Finanziario Società per Azioni }\end{array}$ & 0.88 & 0.96 & 0.84 & 0.98 & 0.92 & 0.89 & 0.94 & 0.83 & 0.98 & 0.94 & 0.98 & 1.02 & 1.01 & 0.99 & 0.98 \\
\hline Banca Carige SpA & 0.83 & 0.89 & 0.83 & 0.86 & 0.31 & 0.91 & 0.90 & 0.90 & 0.85 & 0.28 & 0.91 & 0.98 & 0.92 & 1.01 & 1.11 \\
\hline Swedbank AB & 1.07 & 1.03 & 1.12 & 1.05 & 0.76 & 1.08 & 1.07 & 1.13 & 1.02 & 0.63 & 0.99 & 0.97 & 1.00 & 1.03 & 1.20 \\
\hline AB SEB Bankas & 0.92 & 0.94 & 0.96 & 0.93 & 0.48 & 0.88 & 0.96 & 0.96 & 0.94 & 0.43 & 1.04 & 0.98 & 1.00 & 0.98 & 1.11 \\
\hline Luminor Bank AB & 1.07 & 1.07 & 1.08 & 1.07 & 0.91 & 1.05 & 1.08 & 1.07 & 1.06 & 0.71 & 1.01 & 0.99 & 1.01 & 1.01 & 1.29 \\
\hline Banque Internationale à Luxembourg SA & 0.97 & 0.98 & 0.97 & 1.03 & 0.96 & 1.09 & 1.04 & 0.97 & 1.00 & 0.74 & 0.89 & 0.93 & 1.00 & 1.03 & 1.29 \\
\hline KBL European Private Bankers SA & 1.36 & 1.37 & 1.04 & 1.79 & 1.02 & 0.83 & 0.88 & 0.76 & 0.68 & 0.84 & 1.64 & 1.56 & 1.37 & 2.63 & 1.22 \\
\hline Swedbank AS & 1.00 & 1.00 & 1.00 & 0.96 & 2.82 & 1.03 & 0.99 & 1.01 & 0.91 & 2.49 & 0.97 & 1.01 & 0.99 & 1.06 & 1.13 \\
\hline ABLV Bank AS & 1.10 & 1.07 & 1.12 & 1.16 & 1.45 & 1.03 & 1.05 & 1.09 & 0.99 & 1.26 & 1.06 & 1.02 & 1.03 & 1.18 & 1.15 \\
\hline SEB banka AS & 0.96 & 0.97 & 0.98 & 0.92 & 0.45 & 1.00 & 0.93 & 1.01 & 0.91 & 0.37 & 0.96 & 1.05 & 0.97 & 1.01 & 1.22 \\
\hline Bank of Valletta Plc & 0.94 & 0.96 & 0.92 & 0.99 & 1.29 & 1.01 & 1.02 & 0.96 & 0.90 & 1.08 & 0.93 & 0.94 & 0.96 & 1.10 & 1.20 \\
\hline HSBC Bank Malta Plc & 0.97 & 0.97 & 0.98 & 0.98 & 1.54 & 0.99 & 1.02 & 0.97 & 0.94 & 1.23 & 0.99 & 0.95 & 1.01 & 1.04 & 1.25 \\
\hline ING Bank NV & 0.92 & 0.92 & 0.92 & 0.97 & 0.98 & 0.97 & 0.93 & 0.96 & 0.92 & 0.83 & 0.95 & 0.99 & 0.96 & 1.06 & 1.19 \\
\hline
\end{tabular}




\begin{tabular}{|c|c|c|c|c|c|c|c|c|c|c|c|c|c|c|c|}
\hline ABN AMRO Bank NV & 0.84 & 0.84 & 0.86 & 0.93 & 0.86 & 0.92 & 0.86 & 0.91 & 0.80 & 0.81 & 0.91 & 0.98 & 0.94 & 1.15 & 1.07 \\
\hline De Volksbank N.V. & 1.00 & 1.00 & 1.00 & 1.00 & 1.00 & 1.00 & 1.00 & 1.00 & 1.00 & 1.00 & 1.00 & 1.00 & 1.00 & 1.00 & 1.00 \\
\hline Caixa Geral de Depositos & 0.95 & 1.00 & 0.88 & 0.95 & 1.02 & 1.07 & 0.99 & 0.96 & 0.95 & 0.70 & 0.89 & 1.01 & 0.91 & 1.00 & 1.46 \\
\hline $\begin{array}{l}\text { Banco Comercial Português, SA- } \\
\text { Millennium bcp }\end{array}$ & 1.08 & 1.08 & 1.08 & 1.01 & 1.01 & 1.03 & 1.08 & 1.03 & 1.03 & 0.86 & 1.05 & 1.01 & 1.05 & 0.98 & 1.18 \\
\hline NLB dd-Nova Ljubljanska Banka d.d. & 1.02 & 1.02 & 1.02 & 0.97 & 1.03 & 1.02 & 1.04 & 1.01 & 0.93 & 0.94 & 1.00 & 0.99 & 1.01 & 1.05 & 1.09 \\
\hline Nova Kreditna Banka Maribor d.d. & 1.07 & 1.07 & 1.07 & 0.93 & 1.03 & 1.03 & 1.04 & 1.02 & 0.94 & 0.95 & 1.04 & 1.03 & 1.05 & 0.99 & 1.09 \\
\hline Abanka d.d & 1.00 & 1.01 & 1.02 & 0.67 & 1.62 & 0.99 & 0.98 & 1.00 & 0.68 & 1.51 & 1.01 & 1.03 & 1.03 & 0.98 & 1.08 \\
\hline Vseobecna Uverova Banka a.s. & 1.00 & 0.99 & 1.00 & 1.06 & 0.78 & 1.00 & 1.02 & 0.98 & 0.99 & 0.68 & 1.00 & 0.97 & 1.02 & 1.07 & 1.15 \\
\hline
\end{tabular}

Table S4. Malmquist productivity change and decompositions for the period 2014-2015

\section{$\underline{2014-2015}$}

\section{Productivity Change}

\section{Other}

Net Earning Fixed St

\section{Bank}

Bank für Arbeit und Wirtschaft und

Österreichische Postsparkasse

Aktiengesellschaft-BAWAG P.S.K. AG

Sberbank Europe AG

Belfius Banque SA/NV-Belfius Bank

$\mathrm{SA} / \mathrm{NV}$

Banque Degroof Petercam SA

Bank of Cyprus Public Company Limited-

Bank of Cyprus Group

RCB Bank Ltd

Hellenic Bank Public Company Limited-

Hellenic Bank Group

Deutsche Bank AG

Commerzbank AG

SEB AG

Swedbank As

AS SEB Pank

Banco Santander SA

Banco Bilbao Vizcaya Argentaria SA-

BBVA

Caixabank, S.A.

Banco de Sabadell SA

Banco Popular Espanol SA

$\begin{array}{lllllllllllllll}1.18 & 1.11 & 1.15 & 1.15 & 1.04 & 1.11 & 1.11 & 1.11 & 1.16 & 1.19 & 1.06 & 1.00 & 1.03 & 0.99 & 0.87 \\ 1.03 & 1.04 & 1.02 & 0.91 & 0.77 & 1.06 & 1.05 & 1.09 & 0.82 & 0.85 & 0.97 & 0.99 & 0.94 & 1.11 & 0.90 \\ 1.01 & 1.01 & 1.01 & 1.00 & 0.91 & 0.97 & 1.00 & 0.98 & 0.98 & 1.04 & 1.04 & 1.01 & 1.03 & 1.03 & 0.88 \\ 0.81 & 0.81 & 0.82 & 0.86 & 0.90 & 1.00 & 0.98 & 1.06 & 0.88 & 0.79 & 0.81 & 0.82 & 0.77 & 0.98 & 1.14 \\ 0.97 & 0.99 & 0.97 & 0.95 & 0.57 & 0.99 & 0.98 & 1.00 & 0.85 & 0.62 & 0.98 & 1.00 & 0.97 & 1.12 & 0.92 \\ 0.46 & 1.00 & 0.61 & 1.00 & 1.00 & 1.00 & 1.00 & 1.00 & 1.00 & 1.00 & 0.46 & 1.00 & 0.61 & 1.00 & 1.00 \\ 1.42 & 1.27 & 1.55 & 1.31 & 1.54 & 1.10 & 1.07 & 1.28 & 1.30 & 2.97 & 1.29 & 1.19 & 1.21 & 1.00 & 0.52 \\ 0.99 & 0.98 & 1.03 & 1.01 & 0.93 & 1.19 & 1.15 & 1.04 & 1.08 & 1.06 & 0.83 & 0.85 & 0.99 & 0.93 & 0.88 \\ 1.07 & 1.03 & 1.10 & 1.02 & 0.94 & 1.09 & 1.05 & 1.11 & 0.97 & 1.08 & 0.98 & 0.99 & 0.99 & 1.05 & 0.88 \\ 1.00 & 0.91 & 0.70 & 1.00 & 1.00 & 1.00 & 1.00 & 1.00 & 1.00 & 1.00 & 1.00 & 0.91 & 0.70 & 1.00 \\ 1.06 & 1.00 & 1.03 & 1.04 & 0.72 & 1.01 & 0.98 & 1.00 & 1.02 & 0.86 & 1.05 & 1.02 & 1.03 & 1.02 & 0.84 \\ 1.20 & 1.17 & 1.18 & 1.07 & 4.93 & 1.25 & 1.01 & 1.09 & 1.08 & 4.40 & 0.96 & 1.16 & 1.09 & 0.99 & 1.12 \\ 0.96 & 0.96 & 0.97 & 1.02 & 0.98 & 0.99 & 1.01 & 1.02 & 0.87 & 1.16 & 0.97 & 0.96 & 0.95 & 1.18 & 0.84 \\ 0.93 & 0.93 & 0.93 & 1.10 & 1.00 & 1.02 & 1.04 & 1.05 & 0.91 & 1.06 & 0.91 & 0.90 & 0.89 & 1.21 & 0.94 \\ 0.89 & 0.90 & 0.90 & 0.96 & 0.84 & 0.98 & 0.97 & 0.99 & 0.78 & 1.07 & 0.91 & 0.92 & 0.90 & 1.23 & 0.79 \\ 0.93 & 0.93 & 0.94 & 1.14 & 0.98 & 1.01 & 1.04 & 1.03 & 0.98 & 1.04 & 0.92 & 0.89 & 0.91 & 1.16 & 0.94 \\ 0.98 & 1.00 & 0.99 & 0.99 & 0.90 & 1.00 & 1.01 & 1.02 & 0.92 & 1.03 & 0.98 & 0.98 & 0.97 & 1.07 & 0.88\end{array}$

\section{Efficiency Change $\quad \underline{\text { Technical Change }}$}

Other

Net Earning Fixed Staff Net Earning

Assets Assets Expenses NPLs Loans $\begin{gathered}\text { Assets } \\ \text { Ans }\end{gathered}$

0.87

.90

.88

1.14

0.52

.88

1.00

0.84

0.84

0.94

0.94

0.88 


\begin{tabular}{|c|c|c|c|c|c|c|c|c|c|c|c|c|c|c|c|}
\hline Bankinter SA & 0.94 & 0.96 & 0.95 & 1.00 & 0.86 & 1.00 & 0.99 & 1.01 & 0.91 & 0.88 & 0.93 & 0.97 & 0.94 & 1.10 & 0.98 \\
\hline Kutxabank SA & 0.99 & 1.00 & 1.00 & 0.98 & 1.05 & 0.99 & 1.01 & 1.00 & 0.91 & 1.31 & 1.00 & 0.98 & 1.00 & 1.07 & 0.80 \\
\hline Ibercaja Banco SA & 1.13 & 1.12 & 1.13 & 1.05 & 1.07 & 1.06 & 1.09 & 1.08 & 1.06 & 1.26 & 1.07 & 1.03 & 1.05 & 0.99 & 0.85 \\
\hline Abanca Corporacion Bancaria SA & 0.94 & 0.96 & 0.95 & 0.96 & 0.69 & 1.04 & 1.01 & 1.05 & 0.92 & 0.88 & 0.90 & 0.95 & 0.90 & 1.04 & 0.79 \\
\hline Nordea Bank Finland Plc & 2.23 & 1.11 & 0.94 & 0.83 & 1.00 & 1.00 & 1.00 & 1.00 & 1.00 & 1.00 & 2.23 & 1.11 & 0.94 & 0.83 & 1.00 \\
\hline Danske Bank Plc & 1.25 & 0.98 & 0.47 & 1.02 & 0.69 & 1.01 & 1.05 & 1.21 & 1.00 & 1.30 & 1.24 & 0.93 & 0.39 & 1.02 & 0.53 \\
\hline BNP Paribas & 0.85 & 0.89 & 0.87 & 0.93 & 0.86 & 1.02 & 1.01 & 1.00 & 0.87 & 1.03 & 0.83 & 0.88 & 0.87 & 1.07 & 0.83 \\
\hline Société Générale SA & 0.80 & 0.87 & 0.85 & 0.99 & 0.90 & 1.04 & 1.05 & 1.03 & 0.99 & 1.06 & 0.77 & 0.83 & 0.83 & 1.00 & 0.85 \\
\hline Banque Fédérative du Crédit Mutuel & 0.95 & 0.97 & 0.96 & 1.01 & 1.08 & 0.99 & 1.03 & 1.03 & 0.91 & 1.20 & 0.96 & 0.94 & 0.93 & 1.11 & 0.89 \\
\hline La Banque Postale & 2.64 & 0.63 & 0.39 & 1.51 & 1.04 & 1.00 & 1.00 & 1.00 & 1.00 & 1.00 & 2.64 & 0.63 & 0.39 & 1.51 & 1.04 \\
\hline HSBC France SA & 0.63 & 1.11 & 2.64 & 1.23 & 1.00 & 1.00 & 1.00 & 1.00 & 1.00 & 1.00 & 0.63 & 1.11 & 2.64 & 1.23 & 1.00 \\
\hline RCI Banque SA & 0.41 & 1.00 & 1.51 & 1.00 & 1.00 & 1.00 & 1.00 & 1.00 & 1.00 & 1.00 & 0.41 & 1.00 & 1.51 & 1.00 & 1.00 \\
\hline Piraeus Bank SA & 1.01 & 1.01 & 1.01 & 0.93 & 1.19 & 0.92 & 0.96 & 0.92 & 0.83 & 1.75 & 1.10 & 1.05 & 1.10 & 1.12 & 0.68 \\
\hline National Bank of Greece SA & 1.22 & 1.21 & 1.22 & 0.86 & 1.11 & 1.00 & 1.03 & 1.00 & 0.88 & 1.57 & 1.22 & 1.18 & 1.22 & 0.97 & 0.71 \\
\hline Alpha Bank AE & 1.16 & 1.13 & 1.16 & 1.04 & 1.10 & 0.98 & 1.04 & 0.98 & 0.98 & 1.54 & 1.18 & 1.09 & 1.18 & 1.06 & 0.72 \\
\hline Eurobank Ergasias SA & 1.05 & 1.04 & 1.05 & 1.00 & 0.98 & 0.99 & 1.01 & 0.99 & 0.90 & 1.35 & 1.07 & 1.03 & 1.07 & 1.11 & 0.72 \\
\hline $\begin{array}{l}\text { Bank of Ireland-Governor and Company of } \\
\text { the Bank of Ireland }\end{array}$ & 0.93 & 0.94 & 0.93 & 0.98 & 0.85 & 0.99 & 0.99 & 1.00 & 0.92 & 1.07 & 0.94 & 0.94 & 0.93 & 1.07 & 0.80 \\
\hline Allied Irish Banks plc & 0.99 & 1.01 & 1.01 & 1.00 & 0.91 & 1.02 & 1.04 & 1.04 & 0.93 & 1.14 & 0.98 & 0.97 & 0.97 & 1.07 & 0.80 \\
\hline Citibank Europe Plc & 1.00 & 1.00 & 1.00 & 1.00 & 1.00 & 1.00 & 1.00 & 1.00 & 1.00 & 1.00 & 1.00 & 1.00 & 1.00 & 1.00 & 1.00 \\
\hline Ulster Bank Ireland DAC & 1.00 & 0.95 & 0.95 & 0.91 & 0.96 & 0.97 & 0.93 & 0.93 & 0.85 & 1.22 & 1.03 & 1.03 & 1.02 & 1.06 & 0.79 \\
\hline UniCredit SpA & 0.96 & 0.97 & 0.96 & 0.98 & 1.00 & 1.01 & 1.01 & 1.02 & 0.82 & 1.16 & 0.96 & 0.96 & 0.95 & 1.19 & 0.86 \\
\hline Intesa Sanpaolo & 0.90 & 0.94 & 0.90 & 0.96 & 0.97 & 0.98 & 1.00 & 0.99 & 0.87 & 1.10 & 0.91 & 0.94 & 0.90 & 1.11 & 0.88 \\
\hline $\begin{array}{l}\text { Banca Monte dei Paschi di Siena SpA- } \\
\text { Gruppo Monte dei Paschi di Siena }\end{array}$ & 1.12 & 1.12 & 1.12 & 1.01 & 1.09 & 1.06 & 1.08 & 1.07 & 0.92 & 1.28 & 1.06 & 1.04 & 1.05 & 1.11 & 0.86 \\
\hline $\begin{array}{l}\text { Mediobanca SpA-MEDIOBANCA - Banca } \\
\text { di Credito Finanziario Società per Azioni }\end{array}$ & 0.91 & 0.93 & 0.92 & 0.99 & 0.97 & 1.00 & 0.94 & 0.97 & 0.97 & 1.04 & 0.91 & 0.99 & 0.95 & 1.01 & 0.93 \\
\hline Banca Carige SpA & 1.11 & 1.10 & 1.11 & 0.98 & 1.36 & 0.95 & 0.99 & 0.95 & 0.92 & 1.59 & 1.17 & 1.11 & 1.16 & 1.06 & 0.85 \\
\hline Swedbank AB & 0.97 & 0.98 & 0.99 & 0.98 & 0.85 & 0.93 & 0.97 & 0.97 & 0.87 & 1.09 & 1.04 & 1.01 & 1.03 & 1.13 & 0.78 \\
\hline AB SEB Bankas & 1.05 & 1.00 & 1.04 & 1.07 & 1.10 & 1.08 & 1.13 & 1.10 & 1.08 & 1.37 & 0.97 & 0.89 & 0.94 & 1.00 & 0.81 \\
\hline Luminor Bank $\mathrm{AB}$ & 1.01 & 1.00 & 1.01 & 1.01 & 1.74 & 1.00 & 1.02 & 1.01 & 0.93 & 1.92 & 1.00 & 0.98 & 1.00 & 1.09 & 0.91 \\
\hline Banque Internationale à Luxembourg SA & 0.96 & 0.95 & 0.96 & 1.00 & 1.00 & 0.99 & 0.99 & 1.03 & 0.86 & 1.13 & 0.97 & 0.96 & 0.92 & 1.16 & 0.88 \\
\hline KBL European Private Bankers SA & 1.00 & 0.99 & 1.09 & 1.10 & 0.90 & 0.99 & 1.09 & 1.07 & 1.36 & 0.88 & 1.02 & 0.92 & 1.02 & 0.81 & 1.03 \\
\hline Swedbank AS & 0.97 & 0.97 & 0.97 & 0.98 & 0.50 & 0.98 & 0.99 & 0.99 & 0.90 & 0.59 & 0.99 & 0.98 & 0.98 & 1.09 & 0.84 \\
\hline ABLV Bank AS & 1.14 & 1.08 & 1.13 & 1.26 & 1.18 & 1.15 & 1.13 & 1.18 & 1.09 & 1.54 & 0.99 & 0.95 & 0.95 & 1.15 & 0.77 \\
\hline
\end{tabular}




\begin{tabular}{|c|c|c|c|c|c|c|c|c|c|c|c|c|c|c|c|}
\hline SEB banka AS & 0.99 & 1.00 & 0.95 & 0.97 & 0.96 & 1.00 & 0.99 & 0.96 & 0.94 & 0.98 & 0.99 & 1.01 & 0.99 & 1.03 & 0.98 \\
\hline Bank of Valletta Plc & 0.97 & 0.97 & 0.98 & 1.00 & 1.15 & 1.03 & 1.03 & 1.05 & 0.97 & 1.35 & 0.95 & 0.95 & 0.93 & 1.04 & 0.85 \\
\hline HSBC Bank Malta Plc & 0.87 & 0.88 & 0.89 & 0.89 & 0.88 & 1.01 & 0.97 & 1.02 & 0.73 & 1.19 & 0.87 & 0.91 & 0.87 & 1.20 & 0.74 \\
\hline ING Bank NV & 1.23 & 1.14 & 1.22 & 1.26 & 1.31 & 1.13 & 1.16 & 1.13 & 1.21 & 1.52 & 1.09 & 0.98 & 1.08 & 1.04 & 0.86 \\
\hline ABN AMRO Bank NV & 1.02 & 1.01 & 1.00 & 1.04 & 0.92 & 1.00 & 1.03 & 1.01 & 0.95 & 0.99 & 1.02 & 0.98 & 0.99 & 1.10 & 0.92 \\
\hline De Volksbank N.V. & 0.89 & 0.96 & 0.89 & 0.96 & 0.52 & 0.79 & 0.93 & 0.80 & 0.93 & 0.27 & 1.12 & 1.04 & 1.12 & 1.04 & 1.91 \\
\hline Caixa Geral de Depositos & 0.93 & 0.94 & 0.93 & 0.95 & 0.95 & 1.00 & 0.99 & 0.99 & 0.86 & 1.22 & 0.94 & 0.95 & 0.94 & 1.10 & 0.78 \\
\hline $\begin{array}{l}\text { Banco Comercial Português, SA- } \\
\text { Millennium bcp }\end{array}$ & 1.02 & 1.01 & 1.01 & 0.99 & 1.00 & 0.99 & 1.02 & 1.00 & 0.91 & 1.25 & 1.03 & 1.00 & 1.02 & 1.08 & 0.80 \\
\hline Novo Banco & 0.48 & 0.61 & 0.44 & 0.73 & 0.51 & 0.87 & 0.78 & 0.84 & 0.60 & 0.43 & 0.55 & 0.78 & 0.52 & 1.22 & 1.19 \\
\hline NLB dd-Nova Ljubljanska Banka d.d. & 1.00 & 1.00 & 1.00 & 1.00 & 0.97 & 1.01 & 1.02 & 1.03 & 0.86 & 1.20 & 0.98 & 0.98 & 0.98 & 1.15 & 0.81 \\
\hline Nova Kreditna Banka Maribor d.d. & 1.04 & 1.04 & 1.04 & 0.99 & 1.08 & 1.05 & 1.05 & 1.05 & 0.92 & 1.31 & 1.00 & 0.99 & 0.99 & 1.08 & 0.82 \\
\hline Abanka d.d & 0.82 & 0.82 & 0.81 & 1.32 & 0.96 & 1.05 & 1.05 & 1.05 & 0.99 & 1.01 & 0.78 & 0.78 & 0.78 & 1.33 & 0.95 \\
\hline Vseobecna Uverova Banka a.s. & 1.00 & 0.99 & 0.99 & 1.06 & 1.00 & 1.01 & 1.03 & 1.01 & 0.95 & 1.16 & 0.99 & 0.96 & 0.98 & 1.12 & 0.86 \\
\hline Tatra Banka a.s. & 1.03 & 1.02 & 1.04 & 1.11 & 1.04 & 1.02 & 1.05 & 1.07 & 0.99 & 1.11 & 1.00 & 0.96 & 0.97 & 1.11 & 0.94 \\
\hline
\end{tabular}

Table S5. Malmquist productivity change and decompositions for the period 2015-2016 $\underline{2015-2016}$

\section{Productivity Change}

\begin{tabular}{l}
\multicolumn{1}{c}{ Bank } \\
\hline Bank für Arbeit und Wirtschaft und \\
Österreichische Postsparkasse \\
Aktiengesellschaft-BAWAG P.S.K. AG \\
Sberbank Europe AG \\
Belfius Banque SA/NV-Belfius Bank \\
SA/NV \\
Banque Degroof Petercam SA \\
Bank of Cyprus Public Company Limited- \\
Bank of Cyprus Group \\
RCB Bank Ltd \\
Hellenic Bank Public Company Limited- \\
Hellenic Bank Group \\
Deutsche Bank AG \\
Commerzbank AG \\
SEB AG
\end{tabular}

1.01

0.98

1.00

\section{Efficiency Change}

\section{Other}

Staff Net Earning

Fixed

Staff Other

Earning

Expenses NPLs Loans Assets Assets Expenses NPLs Loans

Fixed Staff Net Earning

$\begin{array}{llll}1.05 & 1.00 & 1.04 & 1.08\end{array}$

$\begin{array}{llllll}1.01 & 1.01 & 1.01 & 1.01 & 1.23 & 1.03\end{array}$

$1.10 \quad 1.05$

1.09

$\begin{array}{ll}1.35 & 0.99\end{array}$

xpenses

$\begin{array}{lll}0.91 & 0.99 & 0.99\end{array}$

Assets

$1.23 \quad 1.03$

$\begin{array}{lll}1.09 & 1.04 \quad 1.28\end{array}$

$1.54 \quad 0.98$

$\begin{array}{lll}0.92 & 0.98 & 0.79\end{array}$

0.79

$\begin{array}{lll}1.02 & 0.98 & 1.02\end{array}$

$1.01 \quad 1.44$

$\begin{array}{lll}1.08 & 1.26 & 1.12\end{array}$

$1.36 \quad 0.73$

$\begin{array}{lll}0.95 & 0.78 & 0.91\end{array}$

$\begin{array}{lll}0.98 & 0.97 & 0.98\end{array}$

$0.99 \quad 1.01$

$\begin{array}{lll}1.01 & 1.04 & 0.92\end{array}$

$1.25 \quad 0.96$

$\begin{array}{lll}0.88 & 0.86 \quad 0.85\end{array}$

$0.69 \quad 0.99$

1.01

1.00

1.02

$0.82 \quad 0.87$

$1.00 \quad 1.00$

$\begin{array}{lll}0.97 & 0.93 & 1.07\end{array}$

$\begin{array}{lll}0.88 & 0.86 \quad 0.83\end{array}$

$\begin{array}{lll}2.55 & 0.64 & 1.00\end{array}$

$\begin{array}{lll}0.80 & 0.78 & 0.93\end{array}$

$\begin{array}{lll}0.87 & 0.91 & 0.78\end{array}$

$\begin{array}{llll}0.98 & 0.99 & 1.02 & 0.96\end{array}$

$\begin{array}{llll}0.99 & 1.01 & 1.00 & 1.03\end{array}$
$0.61 \quad 0.91$

$0.98 \quad 1.18$

$0.83 \quad 1.01$

$1.00 \quad 1.00$ $\begin{array}{lllll}0.95 & 0.79 & 0.77 & 0.45 & 0.75\end{array}$

$\begin{array}{lll}1.14 & 1.12 \quad 1.22\end{array}$

$\begin{array}{lll}1.04 & 1.03 & 1.26\end{array}$

$\begin{array}{lll}1.00 & 1.00 \quad 1.00\end{array}$

$\begin{array}{ll}1.08 & 0.83\end{array}$

$0.94 \quad 0.98$ $\begin{array}{lll}0.97 & 0.98 & 0.82\end{array}$

$1.00 \quad 1.00 \quad 1.00$

0.88

1.00 
Swedbank As

AS SEB Pank

Banco Santander SA

Banco Bilbao Vizcaya Argentaria SA-

BBVA

Caixabank, S.A.

Banco de Sabadell SA

Banco Popular Espanol SA

Bankinter SA

Kutxabank SA

Ibercaja Banco SA

Abanca Corporacion Bancaria SA

Nordea Bank Finland Plc

Danske Bank Plc

BNP Paribas

Société Générale SA

Banque Fédérative du Crédit Mutuel

La Banque Postale

HSBC France SA

RCI Banque SA

Piraeus Bank SA

National Bank of Greece SA

Alpha Bank AE

Eurobank Ergasias SA

Bank of Ireland-Governor and Company of

the Bank of Ireland

Allied Irish Banks plc

Citibank Europe Plc

Ulster Bank Ireland DAC

UniCredit SpA

Intesa Sanpaolo

Banca Monte dei Paschi di Siena SpA-

Gruppo Monte dei Paschi di Siena

Mediobanca SpA-MEDIOBANCA - Banca di Credito Finanziario Società per Azioni

\begin{tabular}{|c|c|c|c|c|c|c|c|c|c|c|c|c|c|c|}
\hline 1.00 & 0.99 & 1.01 & 1.03 & 1.22 & 1.00 & 1.08 & 1.00 & 1.09 & 1.46 & 1.00 & 0.91 & 1.01 & 0.95 & 0.84 \\
\hline 1.03 & 1.08 & 1.02 & 1.01 & 1.48 & 1.05 & 1.16 & 1.04 & 1.02 & 2.18 & 0.98 & 0.93 & 0.98 & 0.99 & 0.68 \\
\hline 1.00 & 1.00 & 1.01 & 1.00 & 0.98 & 1.02 & 1.07 & 1.03 & 1.29 & 1.21 & 0.98 & 0.94 & 0.98 & 0.78 & 0.81 \\
\hline 0.96 & 0.96 & 0.96 & 0.97 & 0.89 & 1.01 & 1.04 & 1.02 & 1.23 & 1.08 & 0.94 & 0.93 & 0.95 & 0.79 & 0.83 \\
\hline 1.10 & 1.08 & 1.10 & 1.06 & 1.08 & 1.05 & 1.11 & 1.05 & 1.44 & 1.29 & 1.05 & 0.97 & 1.04 & 0.74 & 0.84 \\
\hline 0.91 & 0.94 & 0.93 & 0.95 & 0.83 & 0.95 & 1.02 & 0.96 & 1.09 & 1.10 & 0.96 & 0.92 & 0.96 & 0.88 & 0.76 \\
\hline 0.82 & 0.86 & 0.82 & 0.87 & 0.71 & 0.94 & 0.96 & 0.95 & 0.97 & 1.02 & 0.87 & 0.90 & 0.86 & 0.90 & 0.70 \\
\hline 0.91 & 0.93 & 0.91 & 1.04 & 0.81 & 0.95 & 1.07 & 0.96 & 1.16 & 1.02 & 0.96 & 0.87 & 0.95 & 0.90 & 0.79 \\
\hline 1.04 & 1.03 & 1.05 & 1.02 & 0.82 & 0.97 & 1.08 & 0.98 & 1.24 & 0.99 & 1.07 & 0.95 & 1.07 & 0.82 & 0.84 \\
\hline 1.03 & 1.02 & 1.03 & 1.01 & 0.97 & 1.01 & 1.06 & 1.01 & 1.24 & 1.15 & 1.02 & 0.97 & 1.02 & 0.82 & 0.84 \\
\hline 1.04 & 1.03 & 1.05 & 1.04 & 0.87 & 0.95 & 1.06 & 0.96 & 1.24 & 0.98 & 1.10 & 0.97 & 1.09 & 0.84 & 0.88 \\
\hline 0.70 & 1.43 & 1.00 & 1.00 & 1.00 & 1.00 & 1.00 & 1.00 & 1.00 & 1.00 & 0.70 & 1.43 & 1.00 & 1.00 & 1.00 \\
\hline 2.17 & 1.06 & 0.39 & 1.05 & 0.99 & 1.00 & 1.00 & 1.00 & 1.00 & 1.00 & 2.17 & 1.06 & 0.39 & 1.05 & 0.99 \\
\hline 0.90 & 0.94 & 0.92 & 0.98 & 0.96 & 1.14 & 1.13 & 1.18 & 1.29 & 1.10 & 0.79 & 0.83 & 0.78 & 0.76 & 0.87 \\
\hline 0.81 & 0.89 & 0.87 & 0.95 & 0.92 & 1.17 & 1.15 & 1.18 & 1.19 & 1.05 & 0.70 & 0.78 & 0.74 & 0.79 & 0.88 \\
\hline 0.94 & 0.96 & 0.95 & 1.04 & 0.86 & 1.13 & 1.11 & 1.10 & 1.30 & 1.05 & 0.84 & 0.87 & 0.86 & 0.80 & 0.82 \\
\hline 1.00 & 1.00 & 1.00 & 1.00 & 1.00 & 1.00 & 1.00 & 1.00 & 1.00 & 1.00 & 1.00 & 1.00 & 1.00 & 1.00 & 1.00 \\
\hline 1.00 & 1.00 & 1.00 & 1.00 & 1.00 & 1.00 & 1.00 & 1.00 & 1.00 & 1.00 & 1.00 & 1.00 & 1.00 & 1.00 & 1.00 \\
\hline 2.26 & 1.00 & 3.41 & 1.00 & 1.00 & 1.00 & 1.00 & 1.00 & 1.00 & 1.00 & 2.26 & 1.00 & 3.41 & 1.00 & 1.00 \\
\hline 1.22 & 1.18 & 1.22 & 1.10 & 1.04 & 1.12 & 1.20 & 1.12 & 1.52 & 1.16 & 1.09 & 0.98 & 1.09 & 0.72 & 0.90 \\
\hline 1.09 & 1.08 & 1.09 & 1.00 & 0.95 & 1.04 & 1.09 & 1.05 & 1.39 & 1.12 & 1.04 & 0.99 & 1.04 & 0.72 & 0.85 \\
\hline 0.99 & 1.00 & 0.99 & 0.97 & 0.84 & 1.02 & 1.08 & 1.03 & 1.22 & 1.06 & 0.97 & 0.92 & 0.96 & 0.80 & 0.79 \\
\hline 1.01 & 1.02 & 1.01 & 0.99 & 0.88 & 1.03 & 1.08 & 1.04 & 1.29 & 1.03 & 0.98 & 0.94 & 0.97 & 0.77 & 0.85 \\
\hline 0.98 & 0.99 & 0.99 & 0.95 & 0.95 & 1.01 & 1.06 & 1.04 & 1.08 & 1.30 & 0.97 & 0.94 & 0.96 & 0.88 & 0.73 \\
\hline 0.99 & 1.00 & 1.00 & 0.97 & 0.83 & 1.02 & 1.07 & 1.04 & 1.18 & 1.04 & 0.98 & 0.94 & 0.96 & 0.83 & 0.80 \\
\hline 0.20 & 0.41 & 0.56 & 0.71 & 0.37 & 0.56 & 0.60 & 0.71 & 0.51 & 0.63 & 0.36 & 0.68 & 0.80 & 1.40 & 0.60 \\
\hline 1.11 & 1.08 & 1.11 & 1.02 & 1.21 & 1.05 & 1.13 & 1.09 & 1.20 & 1.45 & 1.05 & 0.95 & 1.02 & 0.85 & 0.83 \\
\hline 0.95 & 0.95 & 0.95 & 0.92 & 0.92 & 1.03 & 1.03 & 1.03 & 1.22 & 1.08 & 0.92 & 0.93 & 0.92 & 0.75 & 0.85 \\
\hline 0.93 & 0.96 & 0.93 & 1.00 & 1.04 & 1.12 & 1.12 & 1.13 & 1.26 & 1.22 & 0.83 & 0.86 & 0.83 & 0.79 & 0.85 \\
\hline 0.97 & 0.98 & 0.97 & 0.96 & 0.81 & 1.01 & 1.05 & 1.02 & 1.23 & 1.08 & 0.96 & 0.93 & 0.96 & 0.78 & 0.75 \\
\hline 0.76 & 0.87 & 0.74 & 0.96 & 0.91 & 1.37 & 1.18 & 1.22 & 1.11 & 1.12 & 0.56 & 0.74 & 0.60 & 0.86 & 0.81 \\
\hline
\end{tabular}




\begin{tabular}{|c|c|c|c|c|c|c|c|c|c|c|c|c|c|c|c|}
\hline Banca Carige SpA & 1.11 & 1.10 & 1.10 & 0.94 & 0.95 & 1.14 & 1.16 & 1.15 & 1.22 & 1.30 & 0.97 & 0.95 & 0.96 & 0.77 & 0.73 \\
\hline Swedbank AB & 1.02 & 1.01 & 1.04 & 1.10 & 0.67 & 0.93 & 1.10 & 0.97 & 1.29 & 0.75 & 1.10 & 0.92 & 1.07 & 0.85 & 0.89 \\
\hline AB SEB Bankas & 1.09 & 1.02 & 1.19 & 1.06 & 2.30 & 1.02 & 1.05 & 1.06 & 1.06 & 3.81 & 1.07 & 0.97 & 1.13 & 1.00 & 0.60 \\
\hline Luminor Bank AB & 1.08 & 1.04 & 1.07 & 1.03 & 1.13 & 1.01 & 1.11 & 1.02 & 1.25 & 1.47 & 1.07 & 0.94 & 1.05 & 0.82 & 0.77 \\
\hline Banque Internationale à Luxembourg SA & 1.01 & 1.02 & 1.01 & 1.05 & 1.04 & 0.99 & 1.04 & 1.00 & 1.31 & 1.10 & 1.02 & 0.97 & 1.01 & 0.80 & 0.94 \\
\hline KBL European Private Bankers SA & 1.45 & 1.29 & 1.43 & 1.00 & 1.08 & 1.86 & 1.62 & 1.27 & 2.02 & 1.39 & 0.78 & 0.80 & 1.12 & 0.50 & 0.77 \\
\hline Swedbank AS & 0.99 & 0.99 & 0.99 & 1.02 & 1.06 & 0.98 & 1.06 & 0.98 & 1.22 & 1.17 & 1.01 & 0.93 & 1.01 & 0.84 & 0.90 \\
\hline ABLV Bank AS & 1.10 & 1.06 & 1.13 & 1.28 & 0.84 & 0.91 & 0.90 & 0.98 & 1.32 & 1.00 & 1.21 & 1.19 & 1.15 & 0.97 & 0.84 \\
\hline SEB banka AS & 1.02 & 0.99 & 1.07 & 1.03 & 2.42 & 1.02 & 1.08 & 1.06 & 1.12 & 3.41 & 1.00 & 0.92 & 1.01 & 0.92 & 0.71 \\
\hline Bank of Valletta Plc & 0.97 & 0.98 & 1.00 & 0.99 & 0.97 & 0.96 & 1.00 & 1.00 & 1.16 & 1.04 & 1.01 & 0.98 & 1.00 & 0.86 & 0.93 \\
\hline HSBC Bank Malta Plc & 1.15 & 1.14 & 1.14 & 1.15 & 1.14 & 1.06 & 1.11 & 1.08 & 1.61 & 1.21 & 1.09 & 1.03 & 1.06 & 0.71 & 0.95 \\
\hline ING Bank NV & 0.88 & 0.96 & 0.90 & 0.88 & 0.77 & 0.94 & 1.00 & 0.95 & 0.99 & 1.11 & 0.93 & 0.96 & 0.94 & 0.89 & 0.70 \\
\hline ABN AMRO Bank NV & 0.95 & 0.96 & 0.96 & 0.95 & 0.90 & 1.00 & 1.05 & 1.01 & 1.09 & 1.33 & 0.95 & 0.91 & 0.95 & 0.88 & 0.68 \\
\hline De Volksbank N.V. & 0.98 & 0.98 & 1.06 & 0.99 & 0.91 & 0.95 & 1.00 & 0.98 & 1.00 & 1.43 & 1.03 & 0.97 & 1.07 & 0.99 & 0.64 \\
\hline Caixa Geral de Depositos & 1.08 & 1.07 & 1.08 & 1.02 & 0.92 & 1.00 & 1.09 & 1.00 & 1.29 & 1.08 & 1.08 & 0.98 & 1.07 & 0.79 & 0.85 \\
\hline $\begin{array}{l}\text { Banco Comercial Português, SA- } \\
\text { Millennium bcp }\end{array}$ & 1.61 & 1.35 & 1.54 & 1.10 & 1.52 & 0.93 & 1.22 & 0.95 & 1.52 & 2.05 & 1.73 & 1.10 & 1.62 & 0.72 & 0.74 \\
\hline Novo Banco & 1.17 & 1.13 & 1.16 & 1.01 & 1.08 & 1.07 & 1.12 & 1.06 & 1.37 & 1.29 & 1.10 & 1.01 & 1.09 & 0.74 & 0.84 \\
\hline NLB dd-Nova Ljubljanska Banka d.d. & 0.99 & 0.99 & 1.00 & 1.02 & 0.94 & 1.02 & 1.05 & 1.03 & 1.35 & 1.05 & 0.97 & 0.94 & 0.97 & 0.75 & 0.89 \\
\hline Nova Kreditna Banka Maribor d.d. & 0.93 & 0.94 & 0.94 & 1.00 & 0.96 & 1.01 & 1.01 & 1.01 & 1.26 & 1.03 & 0.93 & 0.93 & 0.93 & 0.80 & 0.93 \\
\hline Abanka d.d & 1.01 & 1.01 & 1.01 & 0.99 & 0.89 & 1.01 & 1.03 & 1.01 & 1.30 & 1.03 & 1.00 & 0.98 & 1.00 & 0.76 & 0.86 \\
\hline Vseobecna Uverova Banka a.s. & 1.00 & 0.99 & 1.00 & 1.10 & 0.75 & 0.99 & 1.10 & 1.00 & 1.30 & 0.87 & 1.01 & 0.90 & 1.00 & 0.84 & 0.86 \\
\hline Tatra Banka a.s. & 0.96 & 0.96 & 0.96 & 1.00 & 0.91 & 1.00 & 1.06 & 1.00 & 1.20 & 1.12 & 0.96 & 0.91 & 0.96 & 0.84 & 0.81 \\
\hline
\end{tabular}

Table S6. Malmquist productivity change and decompositions for the period 2016-2017

\section{$\underline{2016-2017}$}

Productivity Change

\section{Efficiency Change}

Ehiency Change

Other

Bank

Fixed Staff Net Earning Fixed Staff

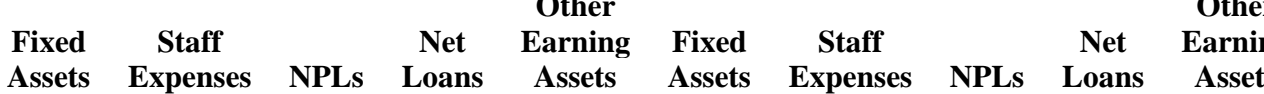

\section{$\underline{\text { Technical Change }}$}

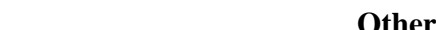

Other

Earning

Bank für Arbeit und Wirtschaft und

$\begin{array}{llllll}0.87 & 0.96 & 0.90 & 1.01 & 1.45 & 0.87\end{array}$

$0.96 \quad 0.82 \quad 0.95$

Assets

Staff
Assets

NPLenses Loans Assets

Osterreichische Postsparkasse

0.87

$\begin{array}{lllll}0.96 & 0.90 & 1.01 & 1.45 & 0.87 \\ & & & & \end{array}$

0.96

Sberbank Europe AG

$\begin{array}{llllll}0.95 & 0.95 & 0.93 & 0.91 & 1.37 & 0.93 \\ 1.00 & 1.00 & 1.00 & 1.00 & 1.00 & 1.00\end{array}$

Belfius Banque SA/NV-Belfius Bank

SA/NV

0.99

$\begin{array}{llllll}0.99 & 1.03 & 1.12 & 0.79 & 0.71\end{array}$

$\begin{array}{lll}0.92 & 0.89 & 0.90\end{array}$

$\begin{array}{lll}1.00 & 1.00 \quad 1.00\end{array}$

$\begin{array}{lll}0.72 & 0.74 & 0.61\end{array}$

$1.65 \quad 1.00$

$\begin{array}{lll}0.99 & 1.09 \quad 1.06\end{array}$

0.88

Banque Degroof Petercam SA

$\begin{array}{ll}1.85 & 1.02 \\ 1.00 & 1.00\end{array}$


Bank of Cyprus Public Company LimitedBank of Cyprus Group

RCB Bank Ltd

Hellenic Bank Public Company Limited-

Hellenic Bank Group

Deutsche Bank AG

Commerzbank AG

\section{SEB AG}

Swedbank As

AS SEB Pank

Banco Santander SA

Banco Bilbao Vizcaya Argentaria SA-

BBVA

Caixabank, S.A.

Banco de Sabadell SA

Bankinter SA

Kutxabank SA

Ibercaja Banco SA

Abanca Corporacion Bancaria SA

\section{BNP Paribas}

Société Générale SA

Banque Fédérative du Crédit Mutuel

La Banque Postale

HSBC France SA

RCI Banque SA

Piraeus Bank SA

National Bank of Greece SA

Alpha Bank AE

Eurobank Ergasias SA

Bank of Ireland-Governor and Company of the Bank of Ireland

Allied Irish Banks plc

Citibank Europe Plc

Ulster Bank Ireland DAC

UniCredit SpA

$\begin{array}{llllll}1.06 & 1.08 & 1.06 & 0.98 & 1.43 & 0.95 \\ 1.00 & 1.00 & 1.00 & 1.00 & 1.00 & 1.00 \\ 0.83 & 0.82 & 0.83 & 0.83 & 0.85 & 0.93 \\ 1.29 & 0.97 & 3.91 & 0.99 & 0.34 & 1.13 \\ 0.94 & 0.96 & 0.95 & 0.96 & 1.00 & 0.93 \\ 1.00 & 1.00 & 1.00 & 1.00 & 1.00 & 1.00 \\ 1.01 & 0.99 & 1.02 & 1.03 & 1.24 & 0.96 \\ 0.83 & 1.03 & 1.44 & 1.28 & 0.18 & 0.67 \\ 0.96 & 0.96 & 0.97 & 1.02 & 1.08 & 1.01 \\ 1.03 & 1.02 & 1.03 & 0.98 & 1.05 & 1.02 \\ 0.96 & 0.96 & 0.96 & 1.02 & 1.16 & 1.02 \\ 0.99 & 1.01 & 0.99 & 0.98 & 1.24 & 0.94 \\ 0.91 & 0.95 & 0.92 & 1.00 & 1.11 & 0.94 \\ 0.98 & 1.00 & 0.99 & 0.99 & 1.02 & 0.89 \\ 0.82 & 0.88 & 0.83 & 0.90 & 0.86 & 0.93 \\ 0.89 & 0.94 & 0.91 & 1.00 & 1.36 & 0.91 \\ 1.03 & 1.04 & 1.02 & 1.04 & 0.98 & 1.10 \\ 0.99 & 1.03 & 0.99 & 0.99 & 0.95 & 1.02 \\ 1.01 & 1.00 & 1.01 & 1.07 & 1.11 & 1.03 \\ 1.00 & 1.00 & 1.00 & 1.00 & 1.00 & 1.00 \\ 1.00 & 1.00 & 1.00 & 1.00 & 1.00 & 1.00 \\ 0.77 & 1.00 & 1.22 & 1.00 & 1.00 & 1.00 \\ 0.86 & 0.94 & 0.85 & 0.89 & 0.48 & 0.91 \\ 0.98 & 1.01 & 0.97 & 0.93 & 0.67 & 0.96 \\ 0.98 & 1.01 & 0.97 & 0.98 & 0.92 & 0.96 \\ 0.96 & 0.97 & 0.94 & 0.94 & 0.81 & 0.97 \\ 0.92 & 0.95 & 0.93 & 0.94 & 1.22 & 0.91 \\ 0.92 & 0.94 & 0.90 & 0.95 & 1.02 & 0.91 \\ 1.06 & 0.93 & 0.74 & 1.01 & 0.82 & 0.93 \\ 1.05 & 1.04 & 1.03 & 1.01 & 1.26 & 0.96 \\ 1.18 & 1.16 & 1.19 & 1.13 & 1.15 & 1.09\end{array}$

(1.0

0.79

1.00

0.82

0.34

0.76

1.00

0.80

0.95

0.86

0.84

0.84

0.76

0.79

0.76

0.78

0.78

0.89

0.92

0.84

1.00

1.00

1.00

0.77

0.79

0.81

0.79

0.76

0.71

0.94

0.77

0.79 


\begin{tabular}{|c|c|c|c|c|c|c|c|c|c|c|c|c|c|c|c|}
\hline Intesa Sanpaolo & 0.91 & 0.91 & 0.91 & 1.05 & 1.04 & 1.04 & 1.01 & 1.03 & 1.11 & 1.09 & 0.87 & 0.90 & 0.89 & 0.94 & 0.96 \\
\hline $\begin{array}{l}\text { Banca Monte dei Paschi di Siena SpA- } \\
\text { Gruppo Monte dei Paschi di Siena }\end{array}$ & 0.99 & 0.98 & 0.99 & 0.88 & 1.03 & 0.99 & 0.93 & 0.98 & 1.01 & 1.08 & 1.00 & 1.05 & 1.01 & 0.87 & 0.96 \\
\hline $\begin{array}{l}\text { Mediobanca SpA-MEDIOBANCA - Banca } \\
\text { di Credito Finanziario Società per Azioni }\end{array}$ & 0.73 & 0.83 & 0.50 & 0.94 & 0.89 & 0.97 & 0.97 & 0.85 & 1.02 & 1.02 & 0.75 & 0.86 & 0.59 & 0.92 & 0.87 \\
\hline Banca Carige SpA & 0.99 & 0.95 & 0.99 & 0.91 & 1.19 & 0.94 & 0.89 & 0.93 & 1.06 & 1.28 & 1.06 & 1.07 & 1.06 & 0.85 & 0.93 \\
\hline Swedbank AB & 1.05 & 1.01 & 1.06 & 1.02 & 1.23 & 0.97 & 0.98 & 0.90 & 0.99 & 1.34 & 1.08 & 1.03 & 1.18 & 1.03 & 0.92 \\
\hline AB SEB Bankas & 1.20 & 1.05 & 1.23 & 1.05 & 0.92 & 1.02 & 1.02 & 0.97 & 1.02 & 0.68 & 1.18 & 1.02 & 1.27 & 1.03 & 1.36 \\
\hline Luminor Bank AB & 1.27 & 0.98 & 1.24 & 1.31 & 0.88 & 0.98 & 1.10 & 0.91 & 1.14 & 0.72 & 1.29 & 0.89 & 1.37 & 1.16 & 1.21 \\
\hline Banque Internationale à Luxembourg SA & 0.94 & 0.95 & 0.95 & 1.03 & 1.04 & 0.91 & 0.94 & 0.86 & 0.96 & 1.29 & 1.04 & 1.01 & 1.11 & 1.08 & 0.80 \\
\hline KBL European Private Bankers SA & 0.73 & 0.61 & 0.53 & 0.69 & 0.69 & 0.39 & 0.39 & 0.56 & 0.18 & 0.58 & 1.89 & 1.54 & 0.95 & 3.81 & 1.17 \\
\hline Swedbank AS & 0.96 & 0.99 & 0.97 & 0.98 & 0.83 & 0.88 & 0.94 & 0.84 & 0.93 & 1.17 & 1.09 & 1.05 & 1.15 & 1.05 & 0.71 \\
\hline ABLV Bank AS & 0.91 & 0.94 & 0.94 & 0.94 & 0.94 & 0.97 & 1.00 & 0.87 & 0.97 & 0.91 & 0.94 & 0.94 & 1.08 & 0.97 & 1.04 \\
\hline SEB banka AS & 1.05 & 1.02 & 1.04 & 1.04 & 0.74 & 0.93 & 0.99 & 0.85 & 1.00 & 0.89 & 1.12 & 1.03 & 1.23 & 1.04 & 0.84 \\
\hline Bank of Valletta Plc & 0.82 & 0.86 & 0.86 & 0.93 & 1.00 & 0.91 & 0.91 & 0.87 & 0.82 & 1.19 & 0.90 & 0.95 & 0.98 & 1.13 & 0.84 \\
\hline HSBC Bank Malta Plc & 0.92 & 0.94 & 0.93 & 0.91 & 0.98 & 0.97 & 0.95 & 0.93 & 0.89 & 1.29 & 0.95 & 0.99 & 1.00 & 1.02 & 0.76 \\
\hline ING Bank NV & 0.98 & 0.98 & 0.97 & 1.00 & 1.14 & 0.94 & 0.96 & 0.87 & 0.95 & 1.39 & 1.04 & 1.02 & 1.13 & 1.05 & 0.82 \\
\hline ABN AMRO Bank NV & 1.21 & 1.17 & 1.22 & 1.09 & 1.28 & 0.97 & 1.07 & 0.91 & 1.16 & 1.52 & 1.24 & 1.10 & 1.33 & 0.94 & 0.84 \\
\hline De Volksbank N.V. & 1.14 & 1.04 & 1.18 & 1.03 & 1.23 & 0.99 & 1.01 & 0.89 & 1.00 & 1.20 & 1.15 & 1.03 & 1.32 & 1.03 & 1.03 \\
\hline Caixa Geral de Depositos & 0.96 & 1.01 & 0.96 & 0.91 & 1.24 & 0.90 & 0.93 & 0.87 & 0.91 & 1.68 & 1.07 & 1.08 & 1.10 & 1.00 & 0.74 \\
\hline $\begin{array}{l}\text { Banco Comercial Português, SA- } \\
\text { Millennium bcp }\end{array}$ & 0.65 & 0.79 & 0.66 & 0.90 & 0.80 & 0.99 & 0.85 & 0.94 & 0.79 & 0.97 & 0.65 & 0.92 & 0.70 & 1.14 & 0.82 \\
\hline Novo Banco & 0.96 & 1.01 & 0.94 & 0.93 & 0.97 & 0.89 & 0.95 & 0.85 & 0.93 & 1.26 & 1.08 & 1.07 & 1.10 & 1.00 & 0.78 \\
\hline NLB dd-Nova Ljubljanska Banka d.d. & 1.00 & 1.00 & 1.01 & 1.00 & 1.17 & 1.02 & 1.00 & 1.01 & 1.02 & 1.43 & 0.99 & 1.00 & 1.00 & 0.98 & 0.82 \\
\hline Nova Kreditna Banka Maribor d.d. & 0.94 & 0.93 & 0.94 & 1.09 & 1.07 & 1.02 & 1.01 & 1.01 & 1.07 & 1.30 & 0.92 & 0.93 & 0.93 & 1.02 & 0.82 \\
\hline Abanka d.d & 0.99 & 1.00 & 0.99 & 1.06 & 1.04 & 0.99 & 1.00 & 0.98 & 1.06 & 1.33 & 1.00 & 1.00 & 1.02 & 1.00 & 0.78 \\
\hline Vseobecna Uverova Banka a.s. & 0.94 & 0.96 & 0.94 & 1.04 & 0.66 & 0.93 & 0.98 & 0.89 & 0.98 & 0.85 & 1.01 & 0.98 & 1.06 & 1.06 & 0.77 \\
\hline Tatra Banka a.s. & 0.95 & 0.96 & 0.95 & 1.04 & 1.05 & 0.92 & 0.96 & 0.86 & 0.97 & 1.41 & 1.03 & 1.00 & 1.10 & 1.08 & 0.75 \\
\hline
\end{tabular}


Figure S1. Convergence in productivity for the period 2011-2012

$\beta$-Convergence \& Liquid Assets Ratio
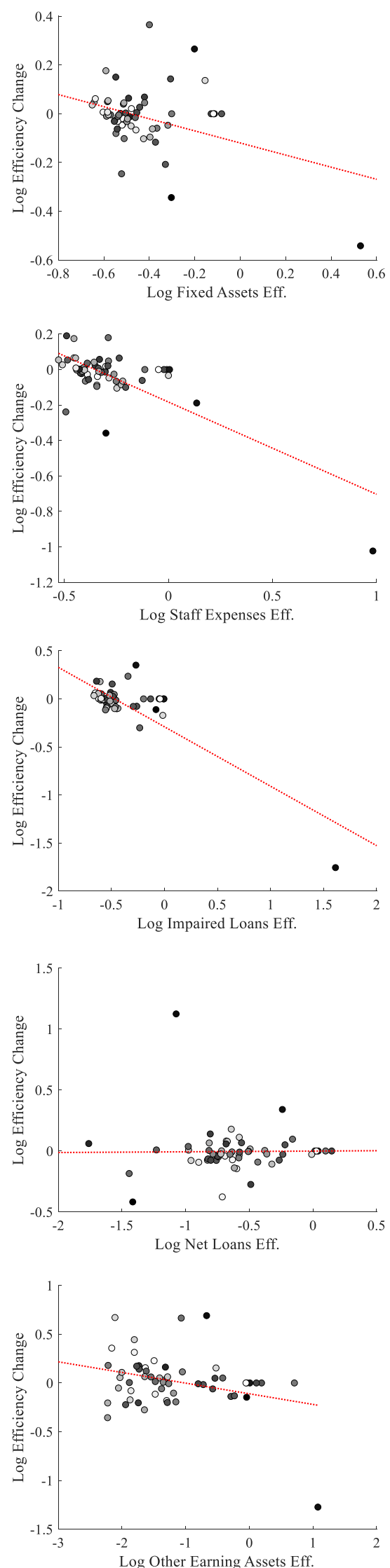

$\beta$-Convergence \& Capital Adeq. Ratio
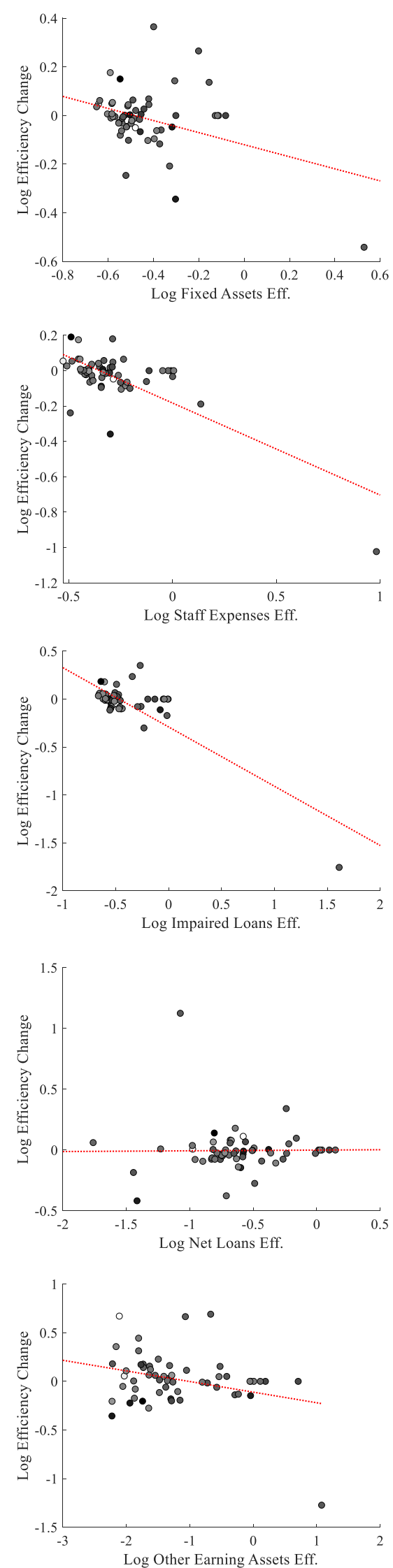

$\underline{\text { Kernel Densities }}$
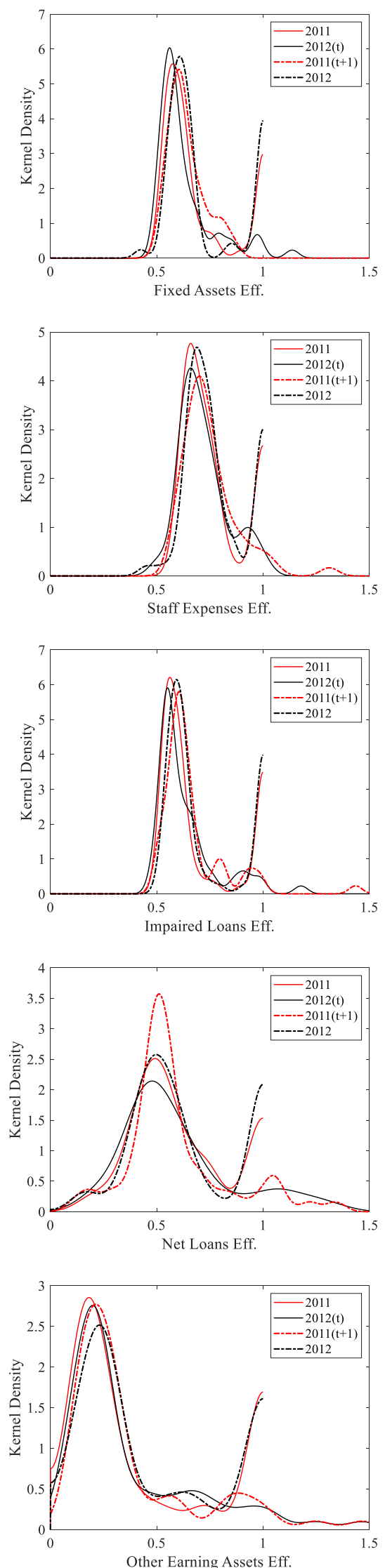
Figure S2. Convergence in efficiency for the period 2011-2012

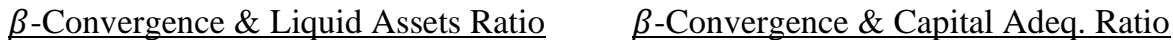
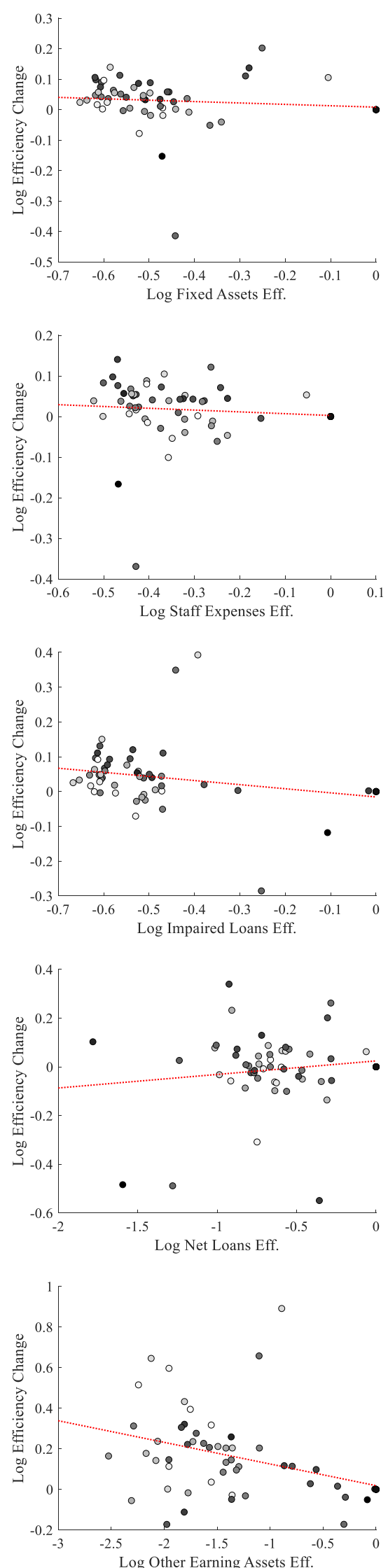
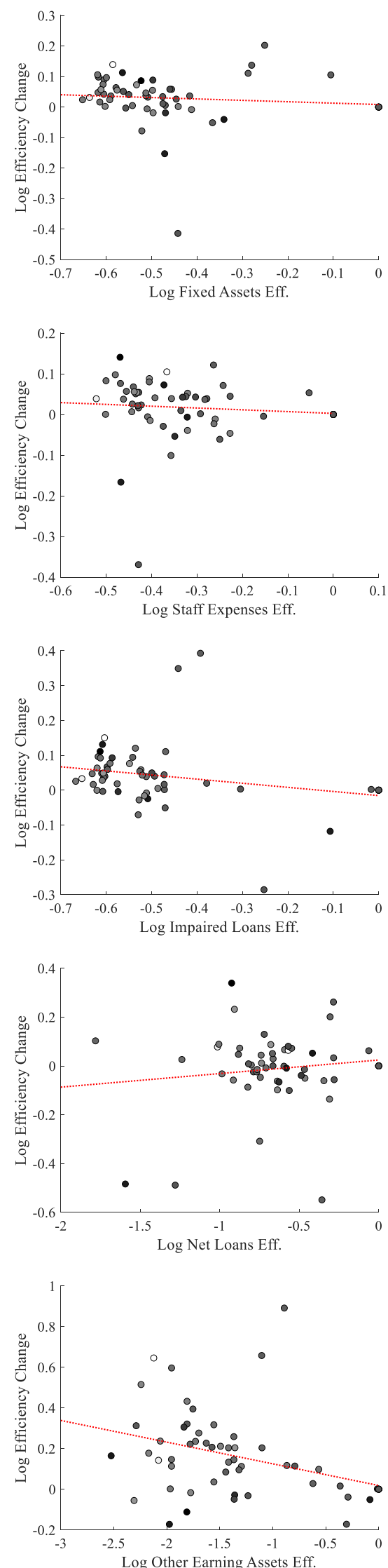
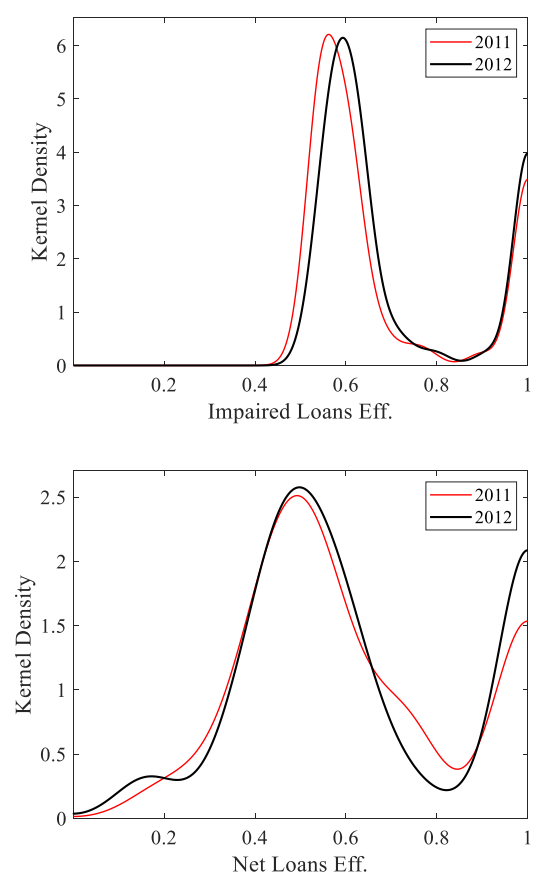

$\underline{\text { Kernel Densities }}$
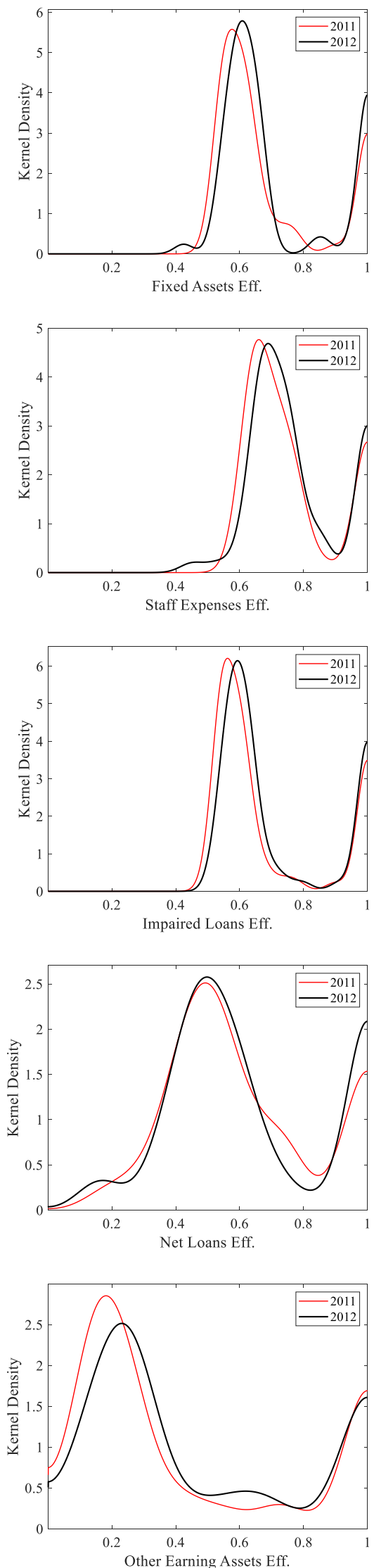
Figure S3. Convergence in technology for the period 2011-2012
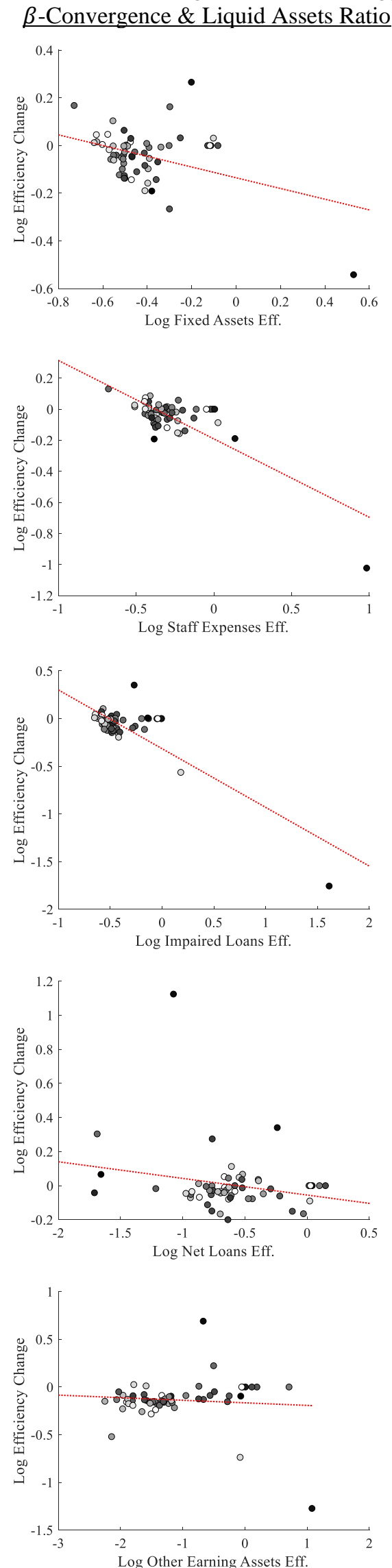

$\underline{\beta}$-Convergence \& Capital Adeq. Ratio
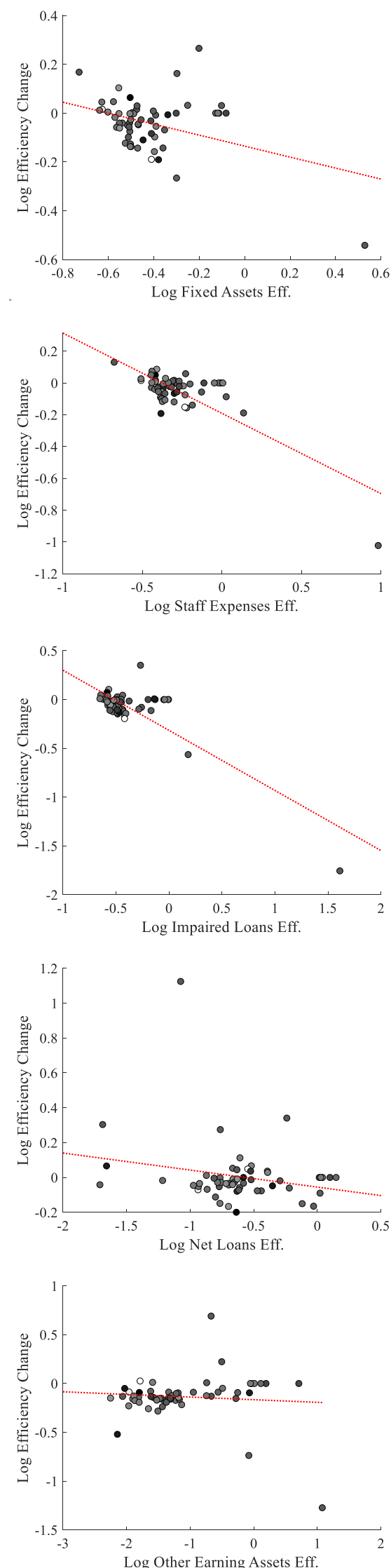

$\underline{\text { Kernel Densities }}$
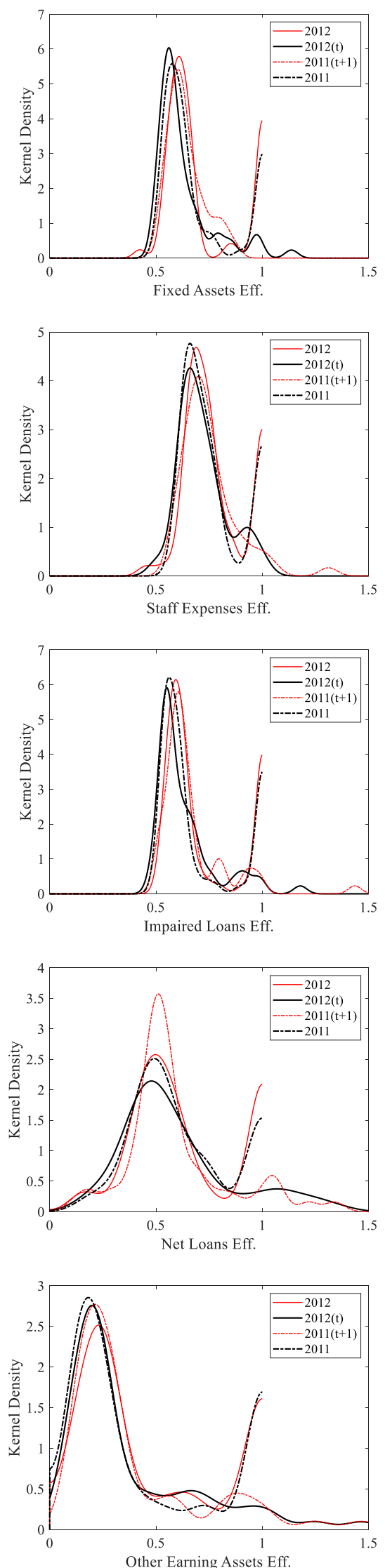
Figure S4. Convergence in productivity for the period 2012-2013

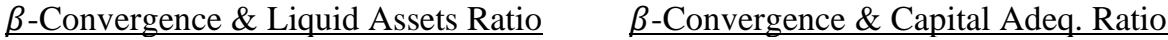
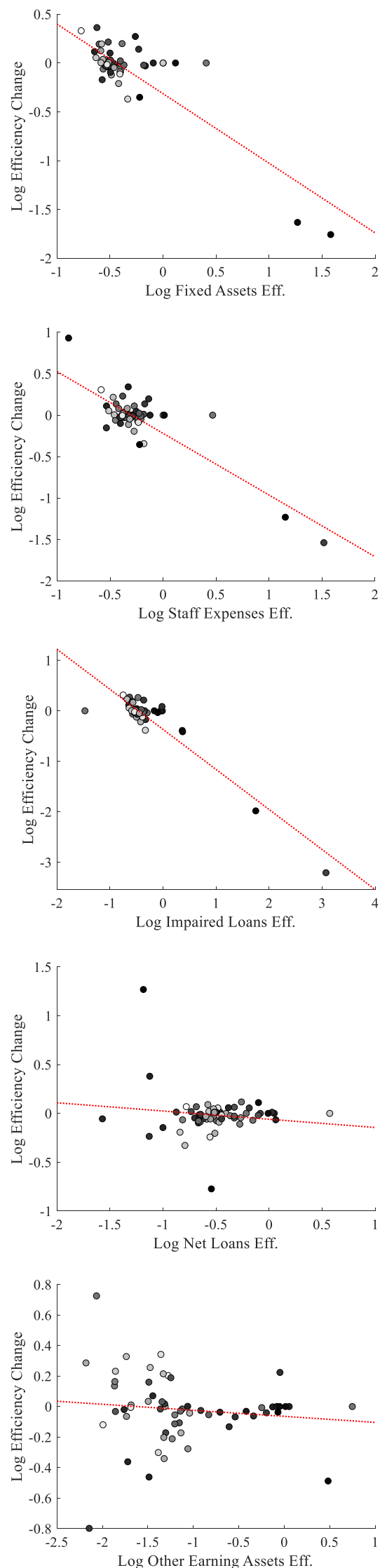
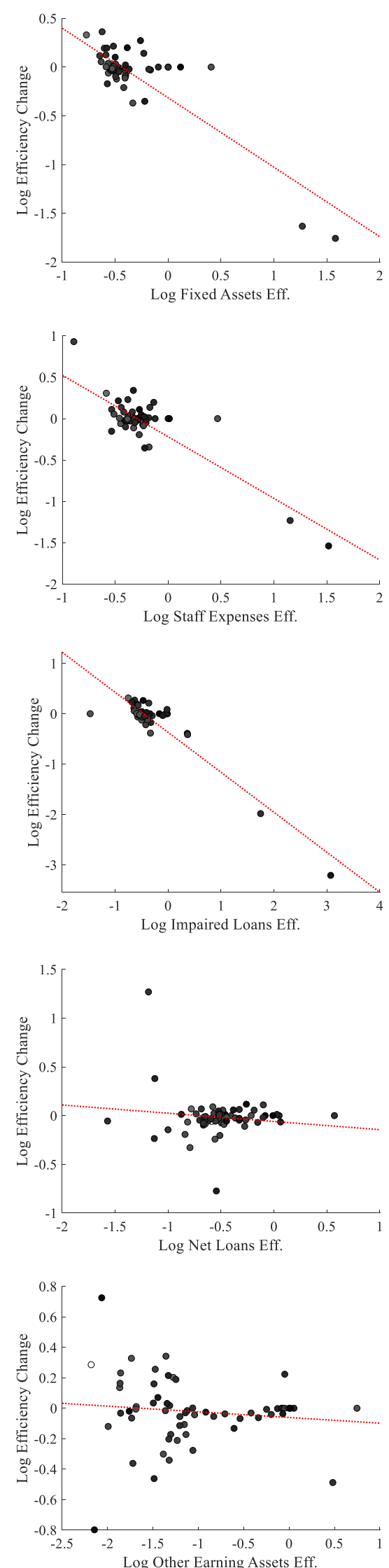

$\underline{\text { Kernel Densities }}$
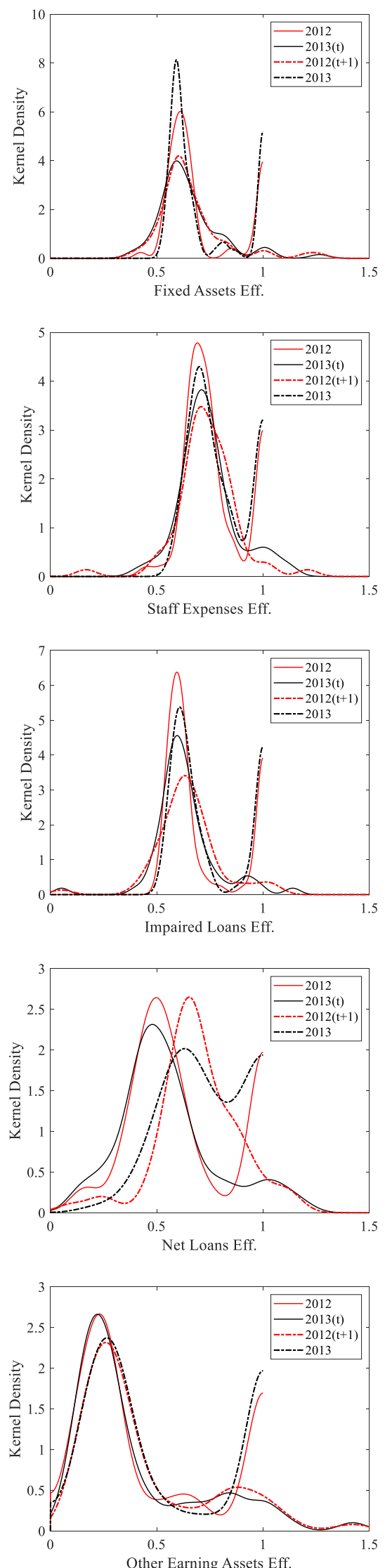
Figure S5. Convergence in efficiency for the period 2012-2013

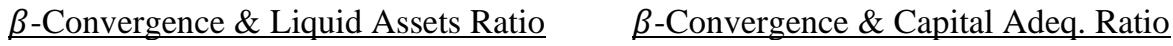
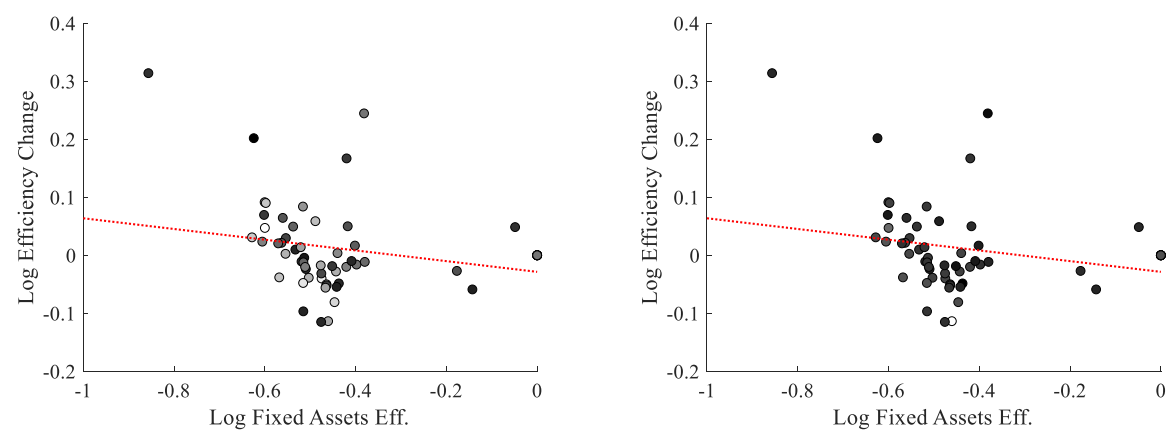

$\underline{\text { Kernel Densities }}$
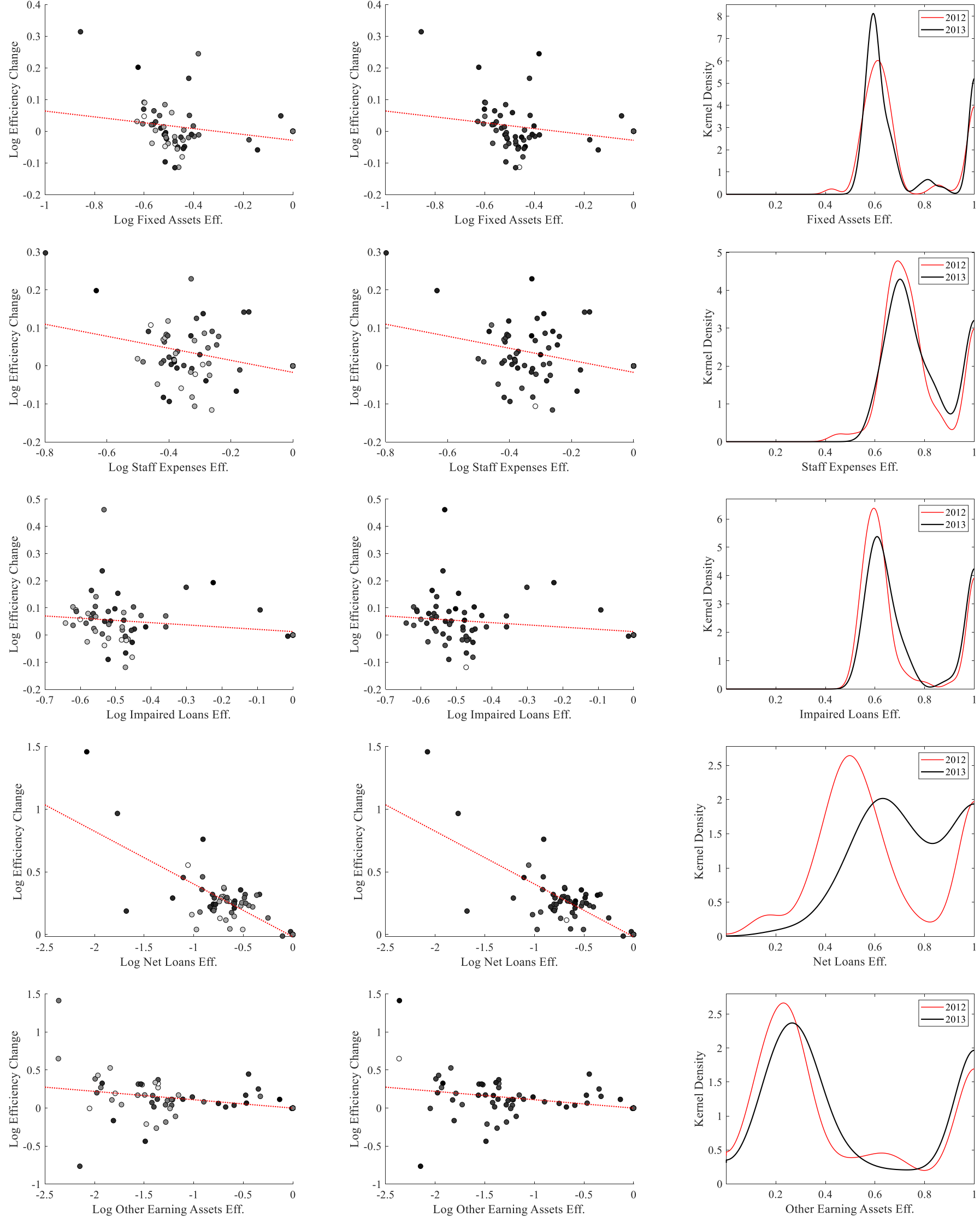
Figure S6. Convergence in technology for the period 2012-2013

$\underline{\beta \text {-Convergence \& Liquid Assets Ratio } \quad \beta \text {-Convergence \& Capital Adeq. Ratio }}$
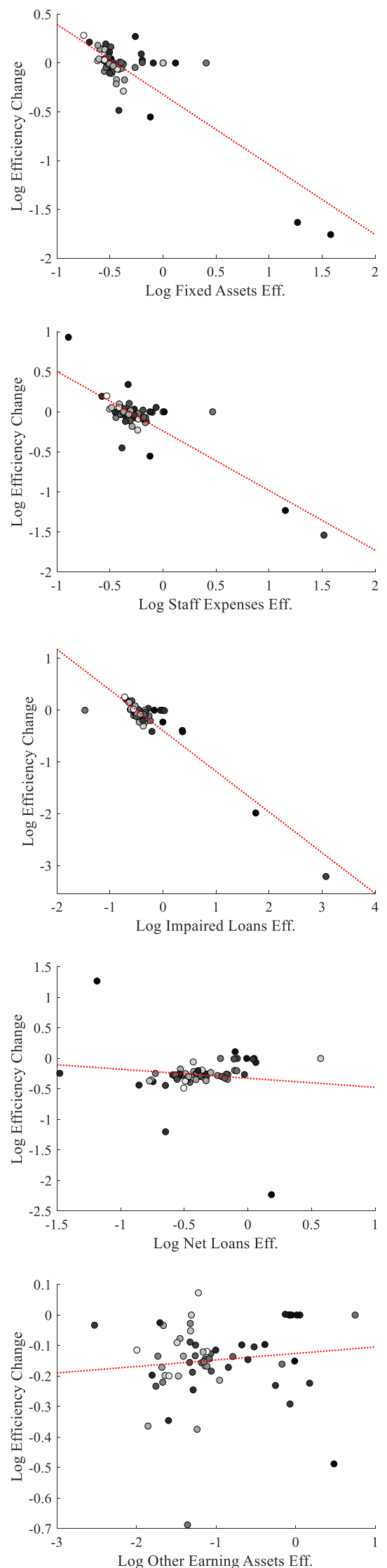
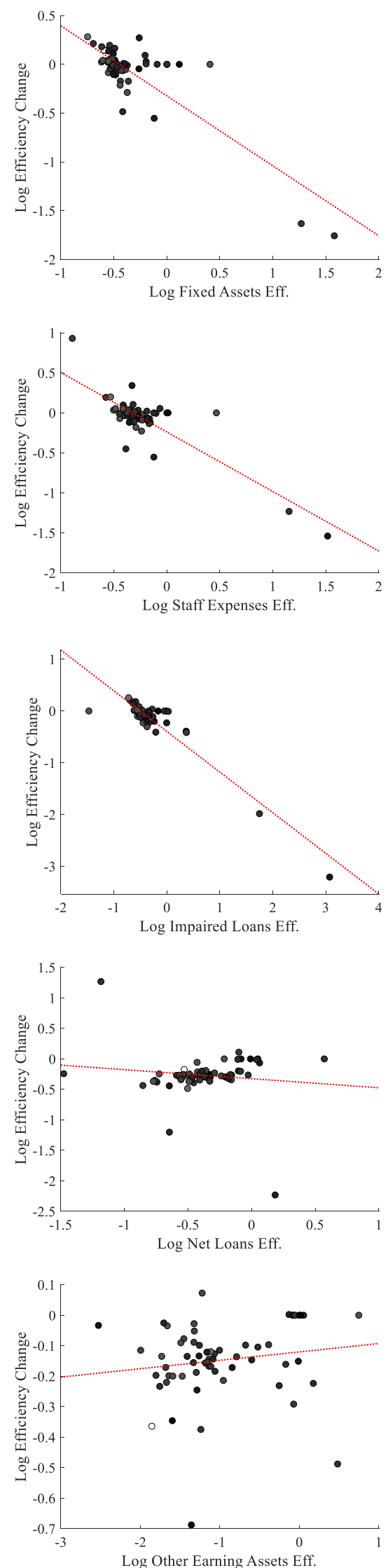

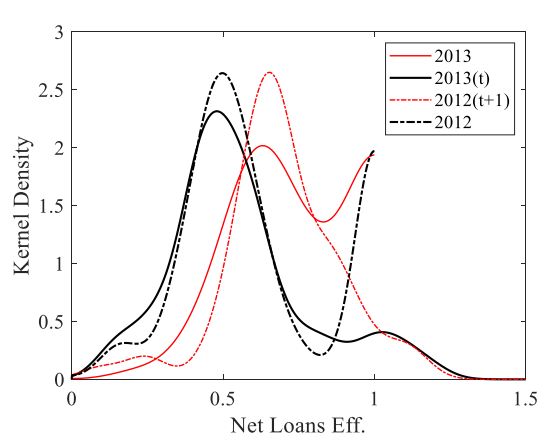

$\underline{\text { Kernel Densities }}$
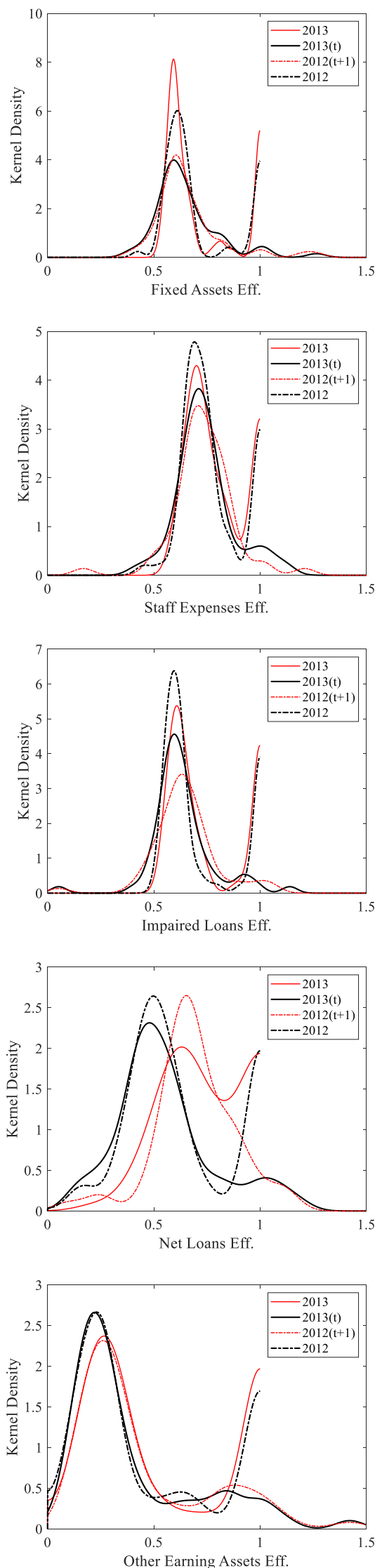
Figure S7. Convergence in productivity for the period 2013-2014

$\beta$-Convergence \& Liquid Assets Ratio
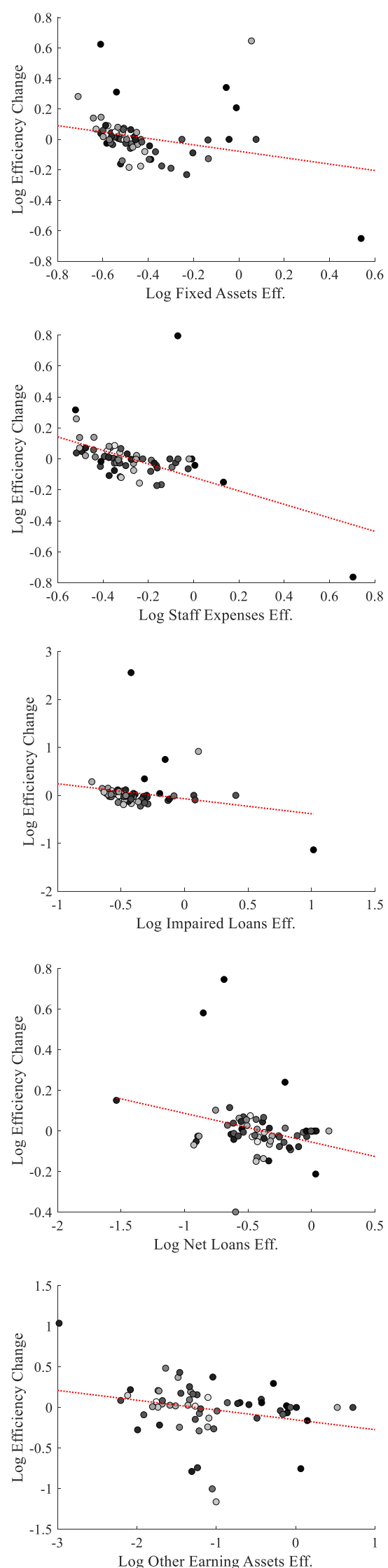

$\beta$-Convergence \& Capital Adeq. Ratio
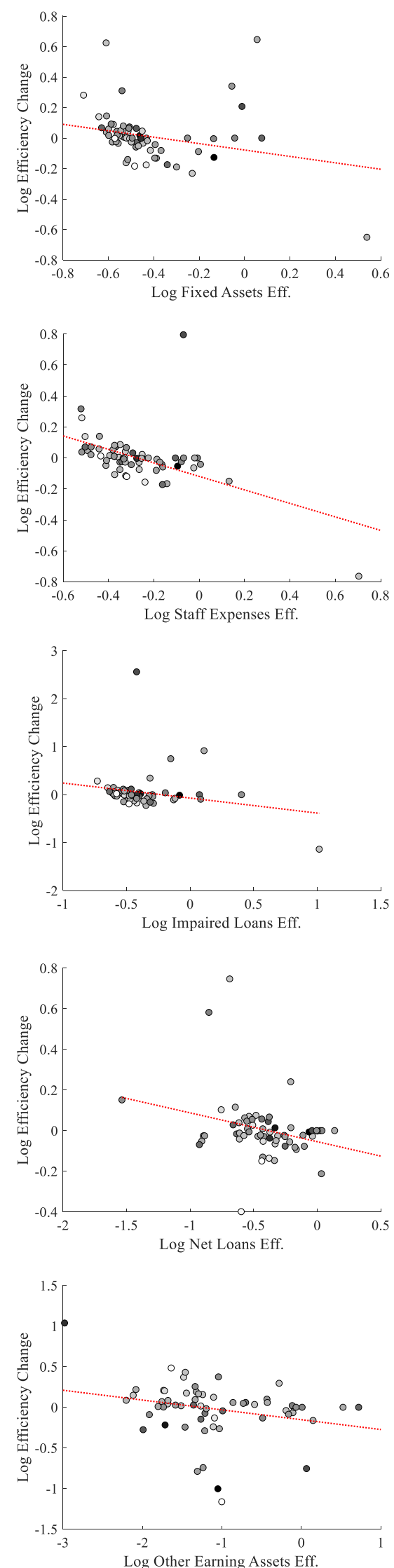

$\underline{\text { Kernel Densities }}$
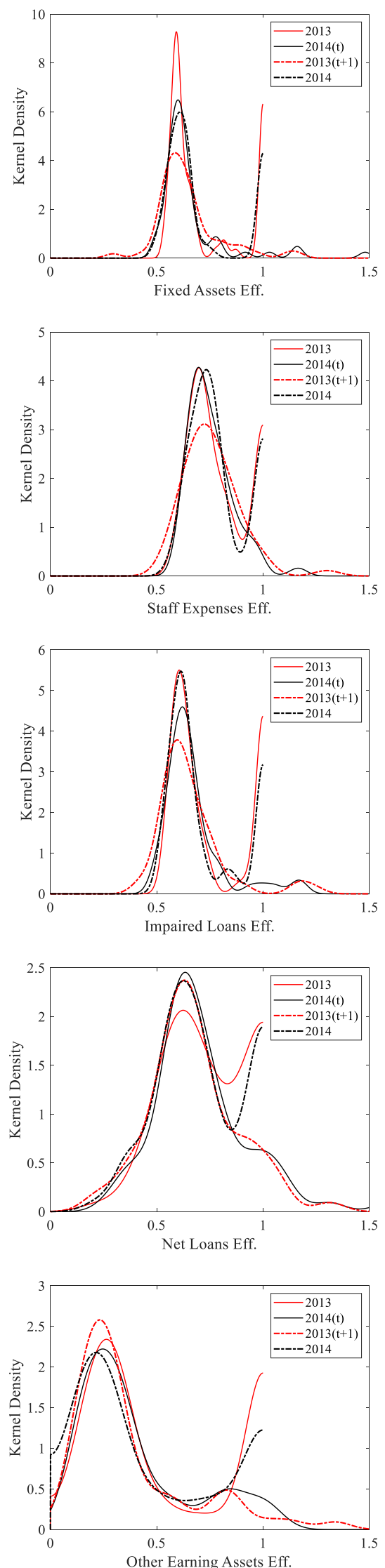
Figure S8. Convergence in efficiency for the period 2013-2014

$\beta$-Convergence \& Liquid Assets Ratio $\quad \beta$-Convergence \& Capital Adeq. Ratio
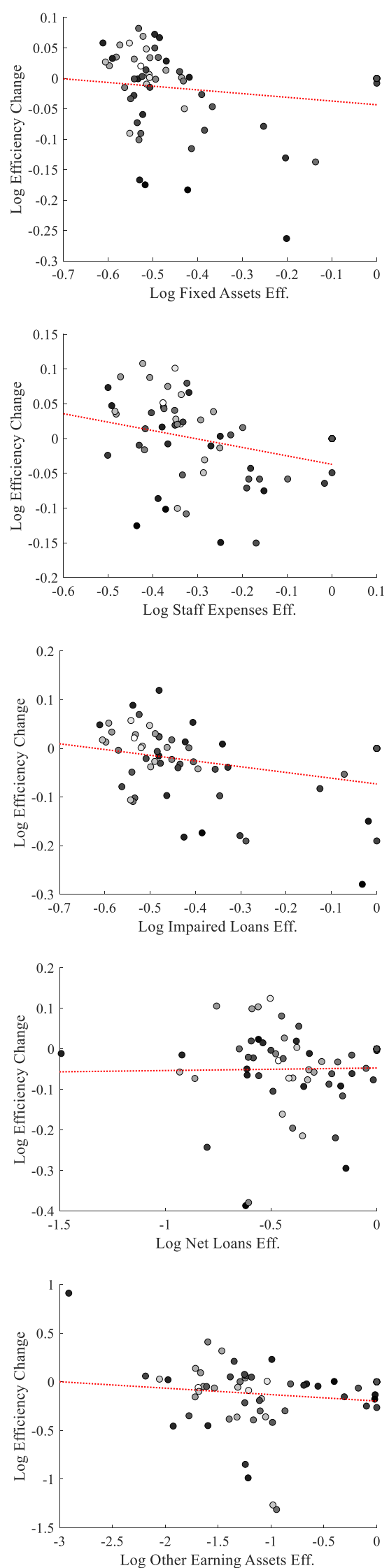
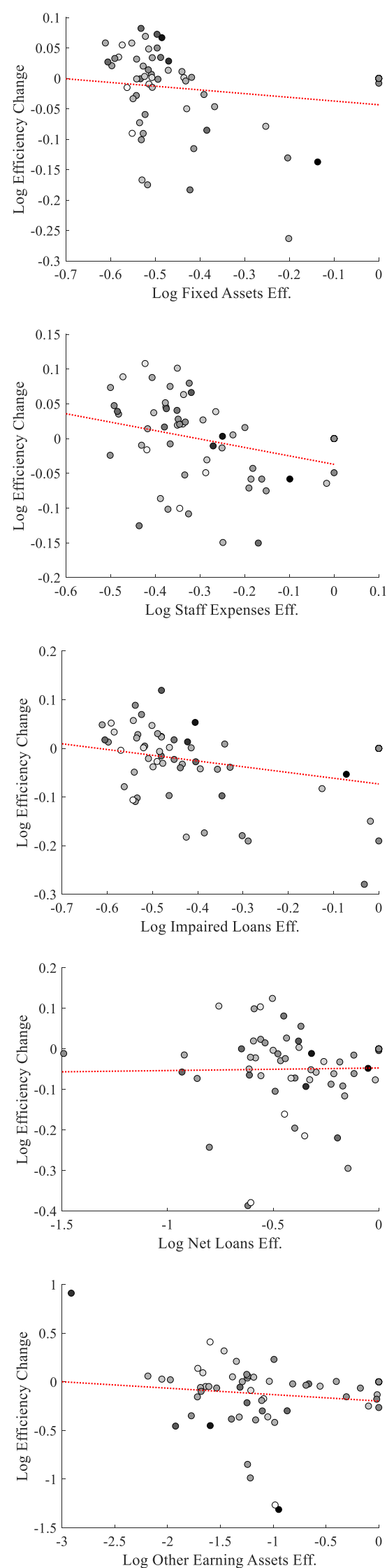

$\underline{\text { Kernel Densities }}$
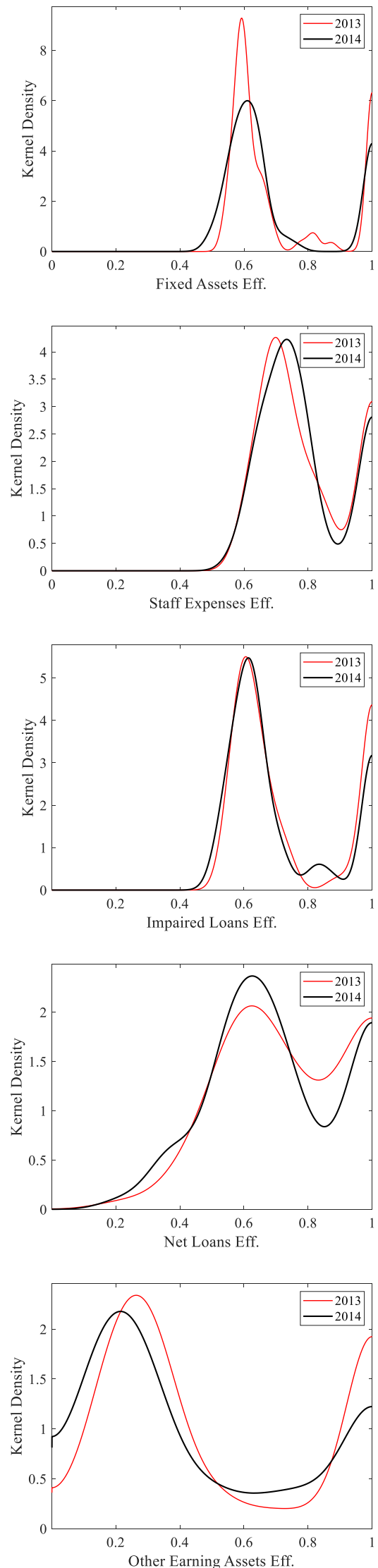
Figure S9. Convergence in technology for the period 2013-2014

$\beta$-Convergence \& Liquid Assets Ratio $\quad \underline{\beta \text {-Convergence \& Capital Adeq. Ratio }}$
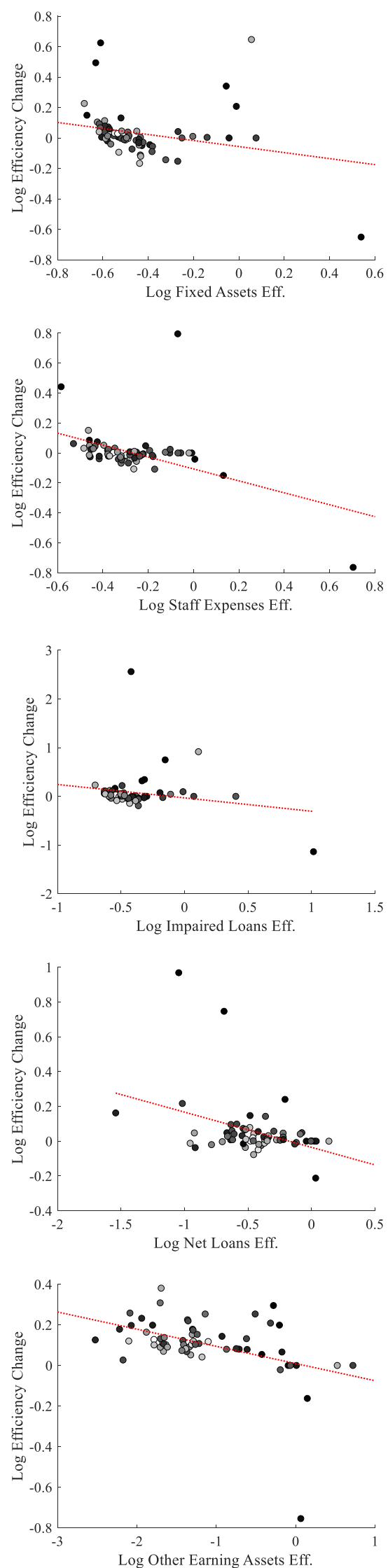
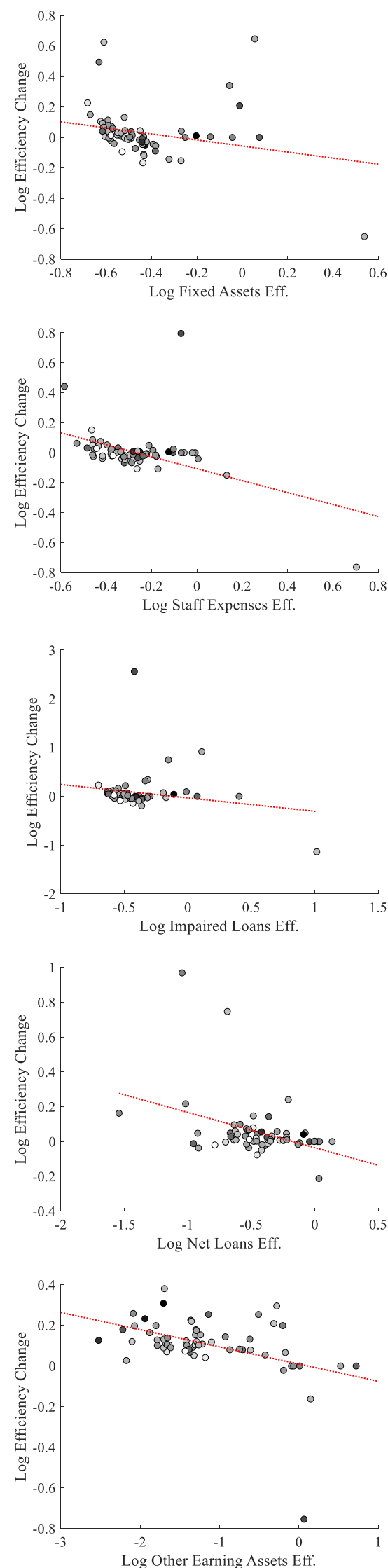

$\underline{\text { Kernel Densities }}$
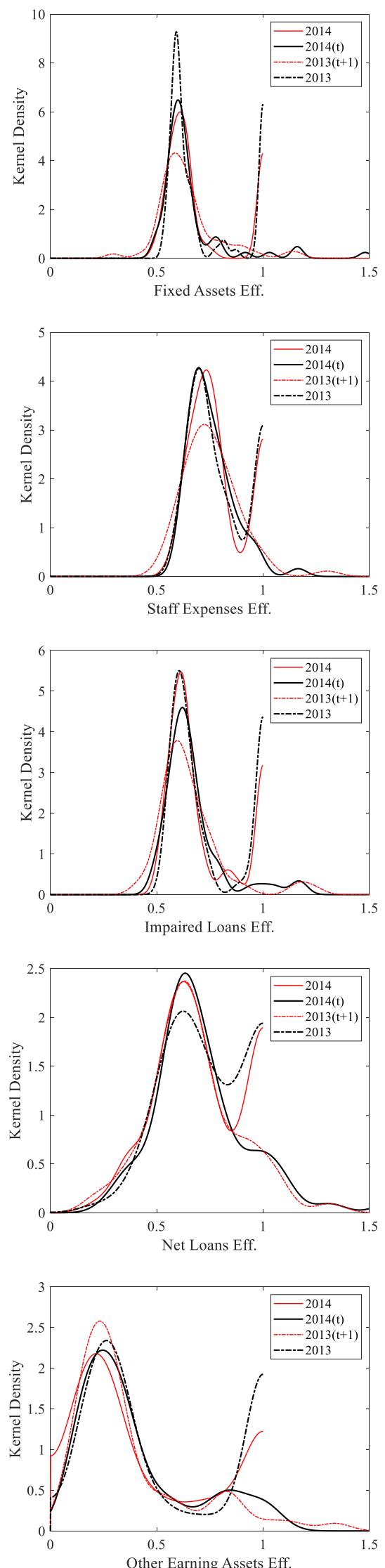
Figure S10. Convergence in productivity for the period 2014-2015

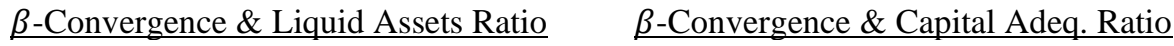
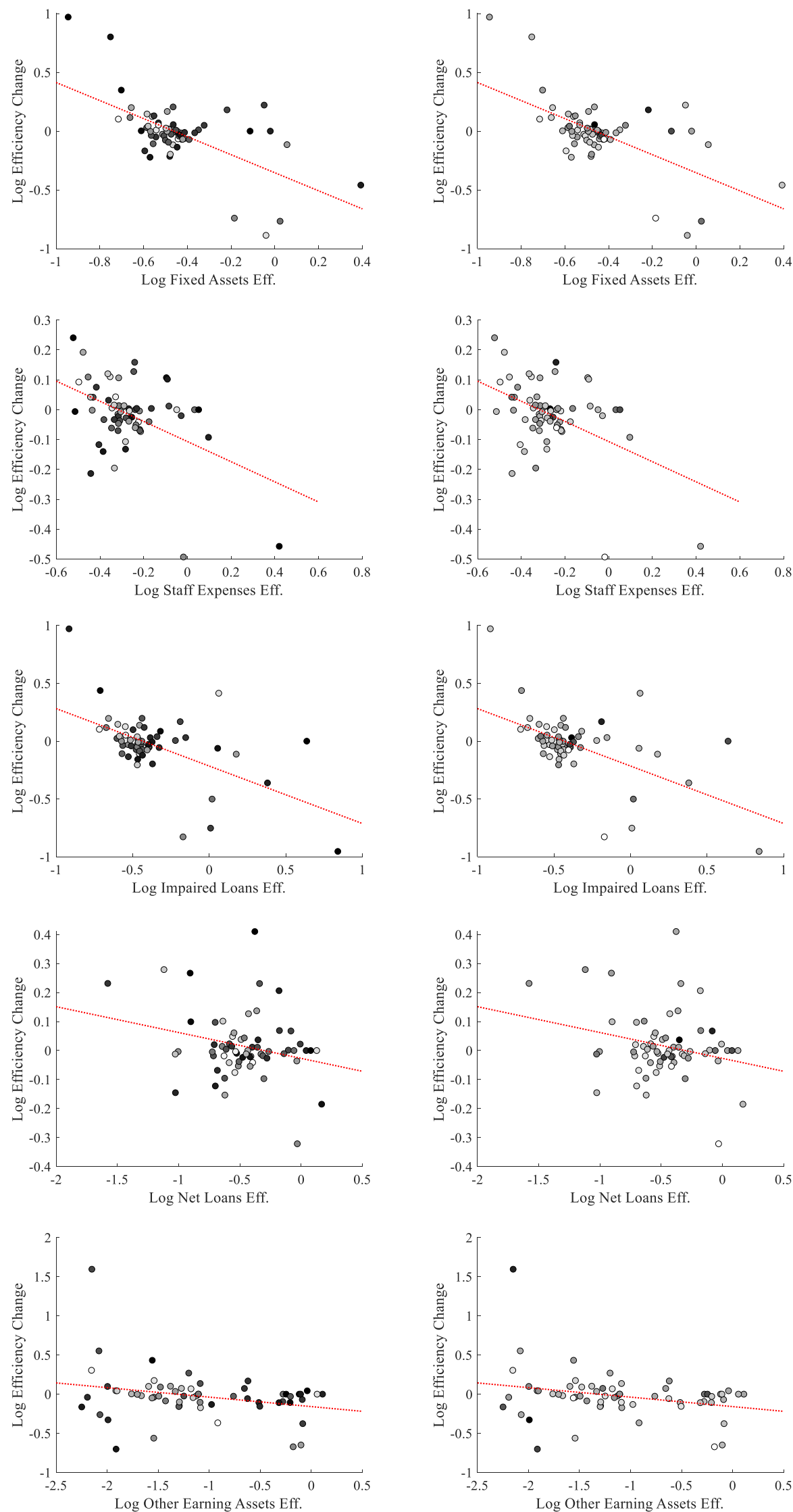
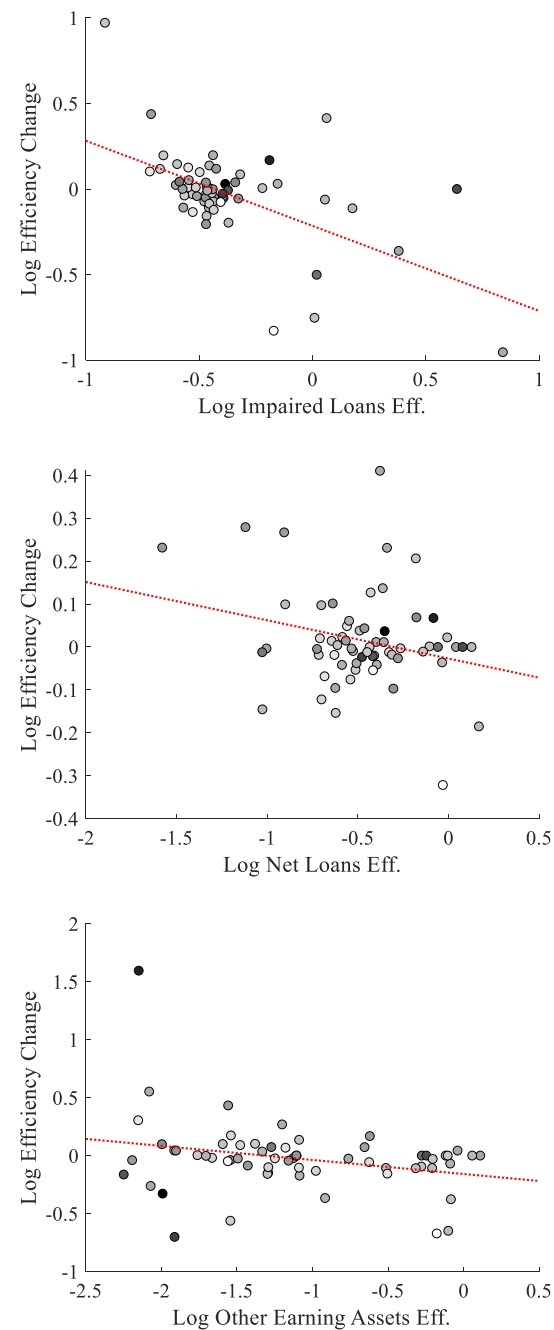

$\underline{\text { Kernel Densities }}$
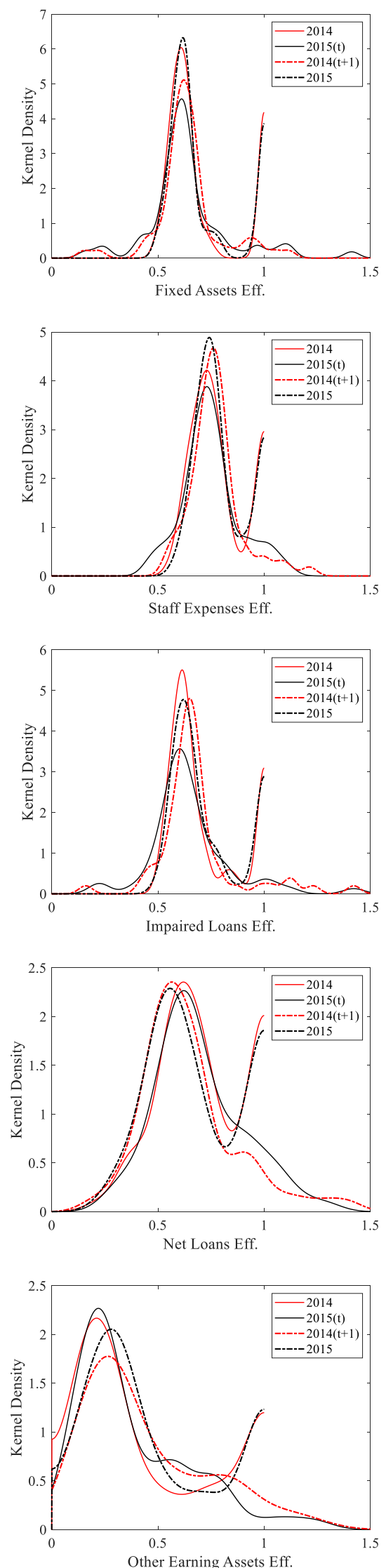
Figure S11. Convergence in efficiency for the period 2014-2015

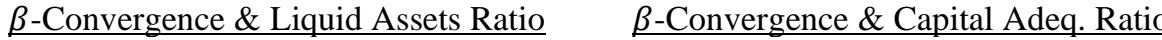
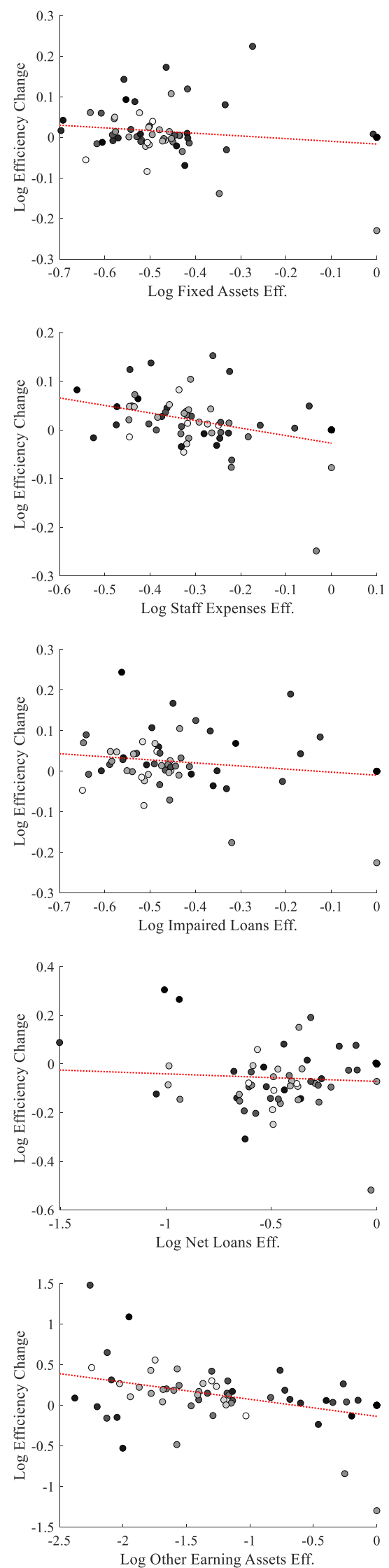
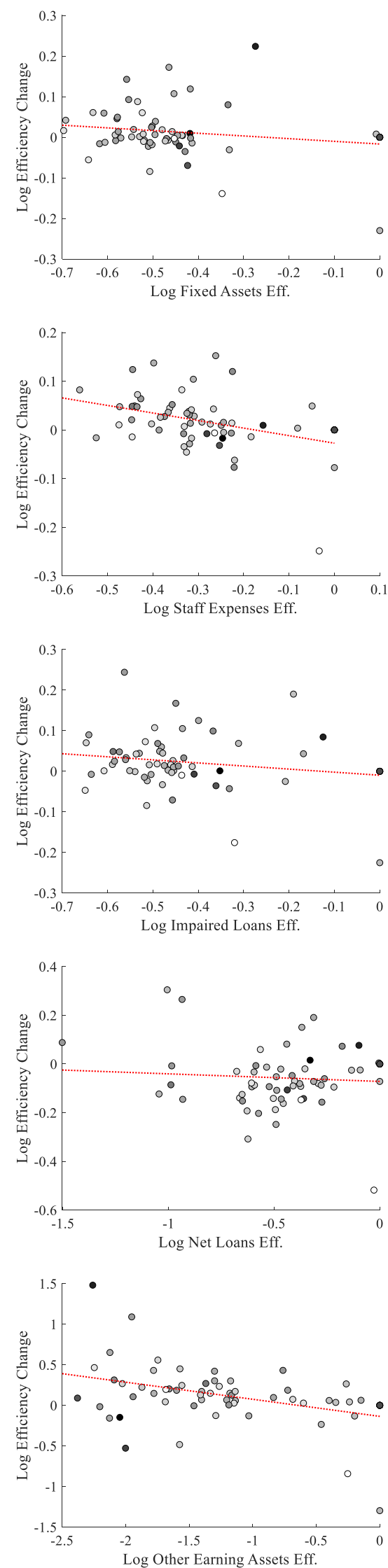

$\underline{\text { Kernel Densities }}$
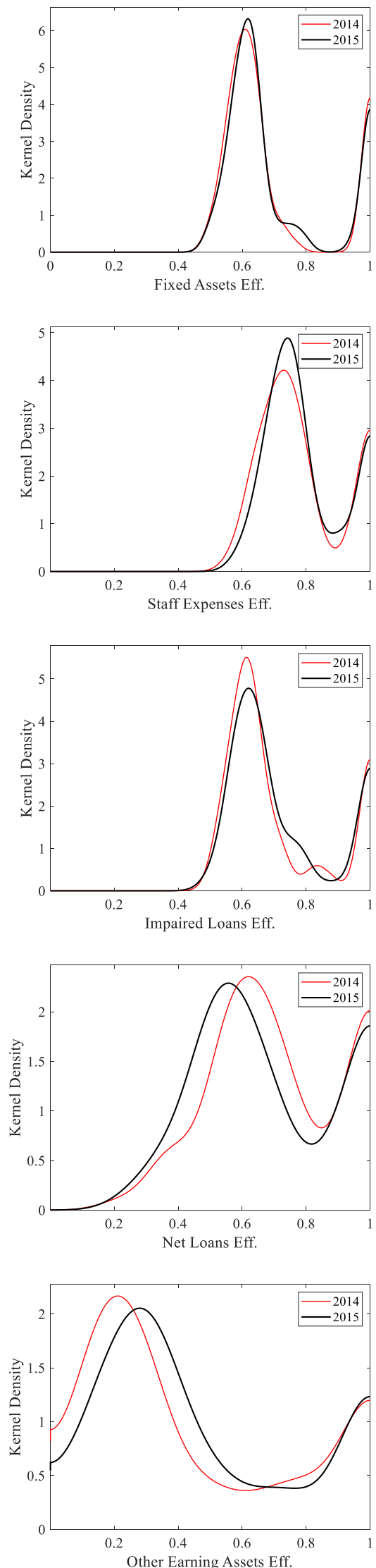
Figure S12. Convergence in technology for the period 2014-2015

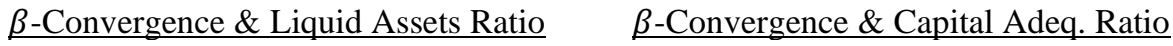
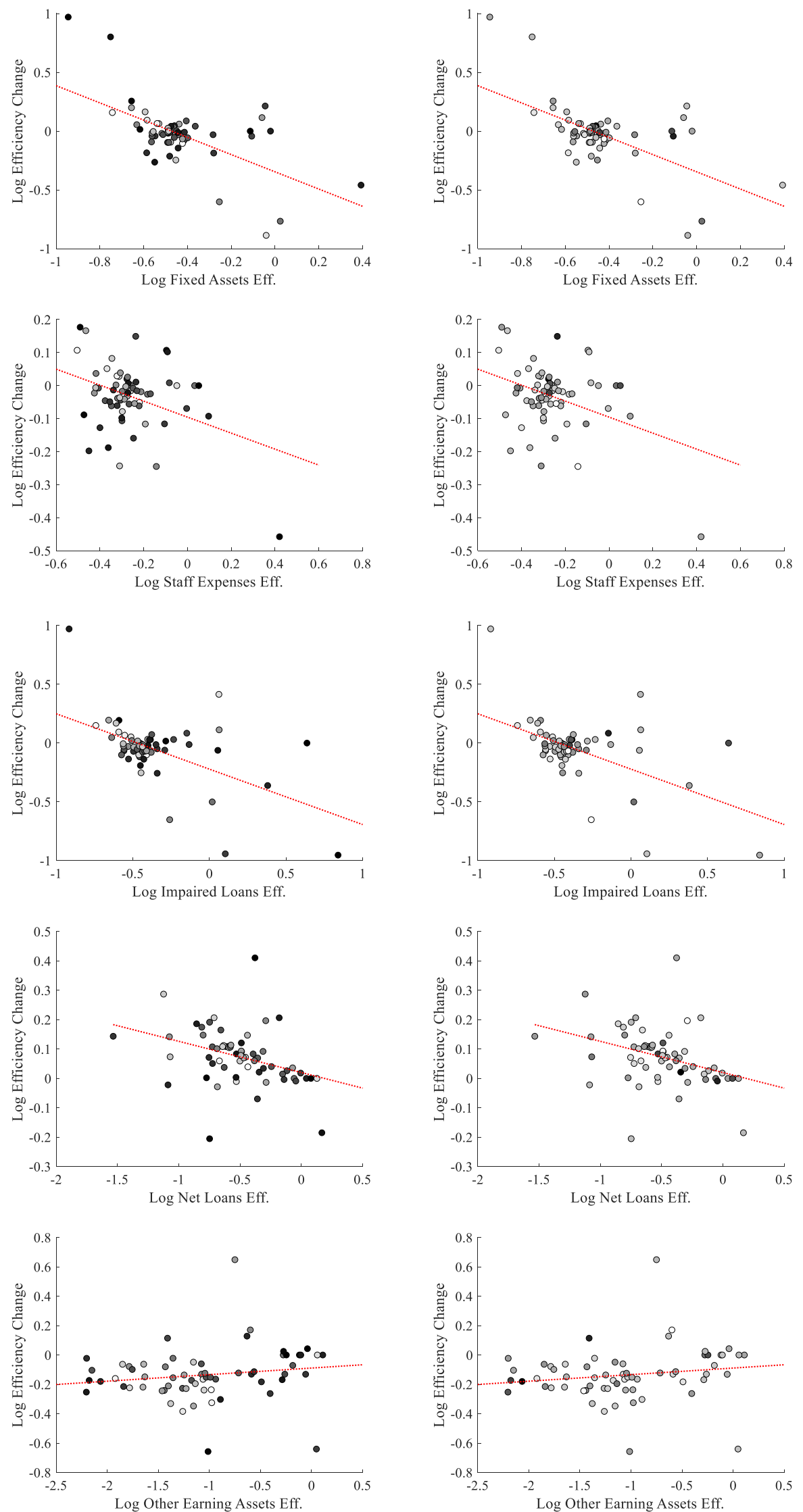
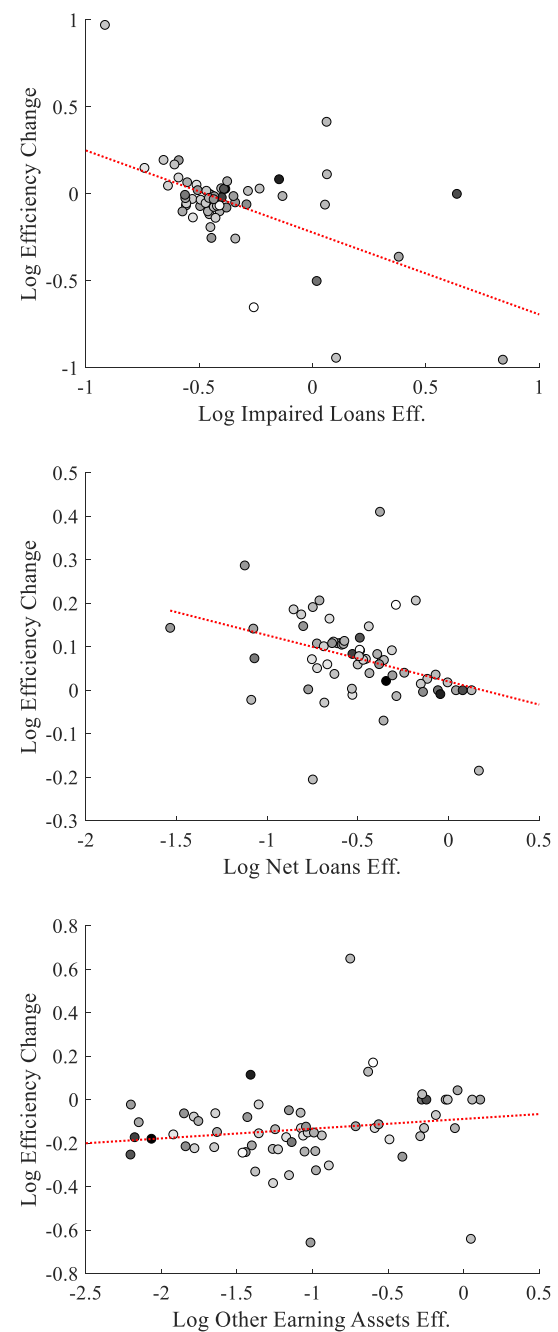

$\underline{\text { Kernel Densities }}$
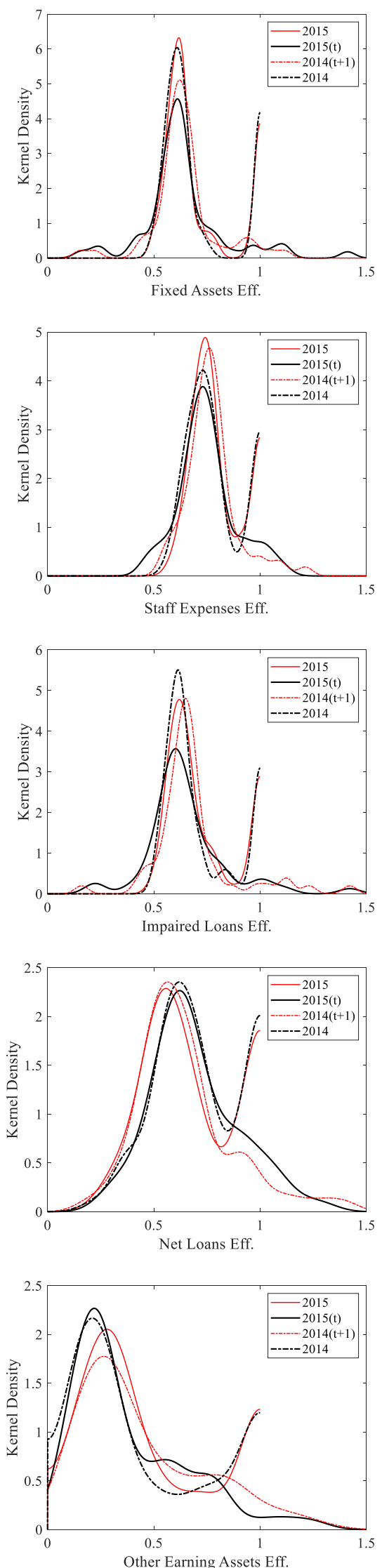
Figure S13. Convergence in productivity for the period 2015-2016

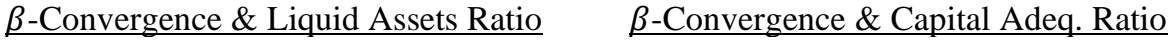
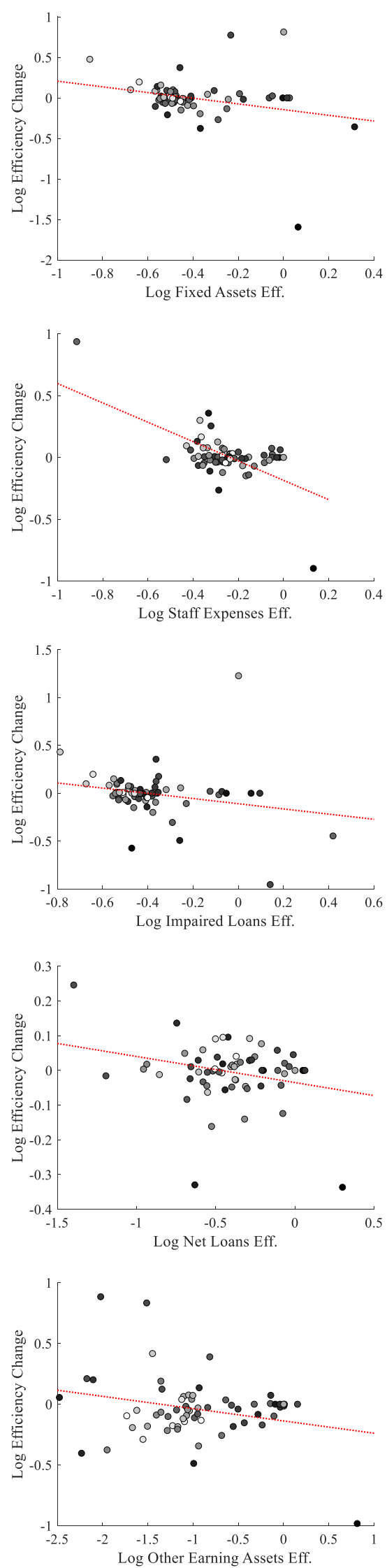
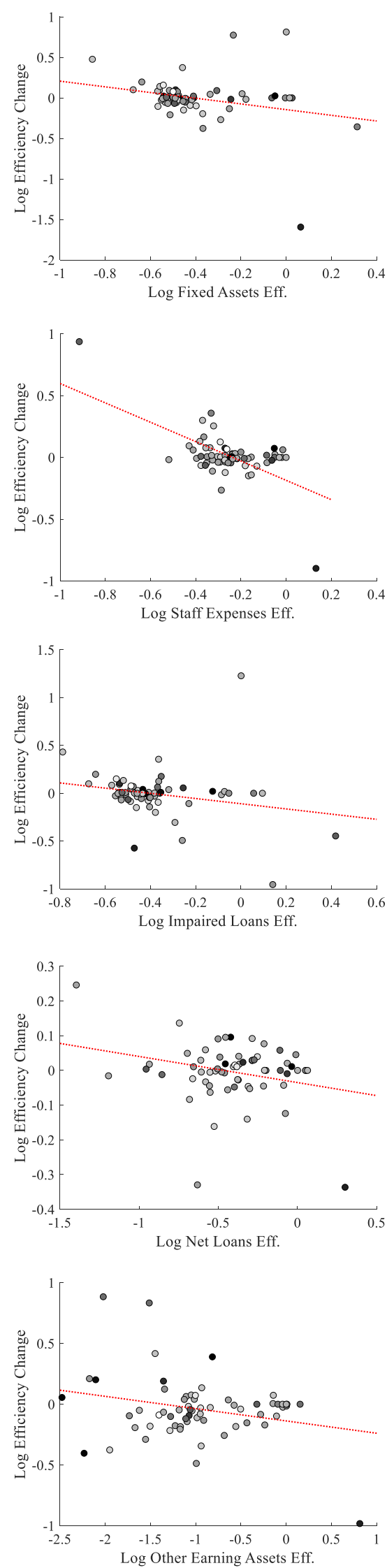

$\underline{\text { Kernel Densities }}$
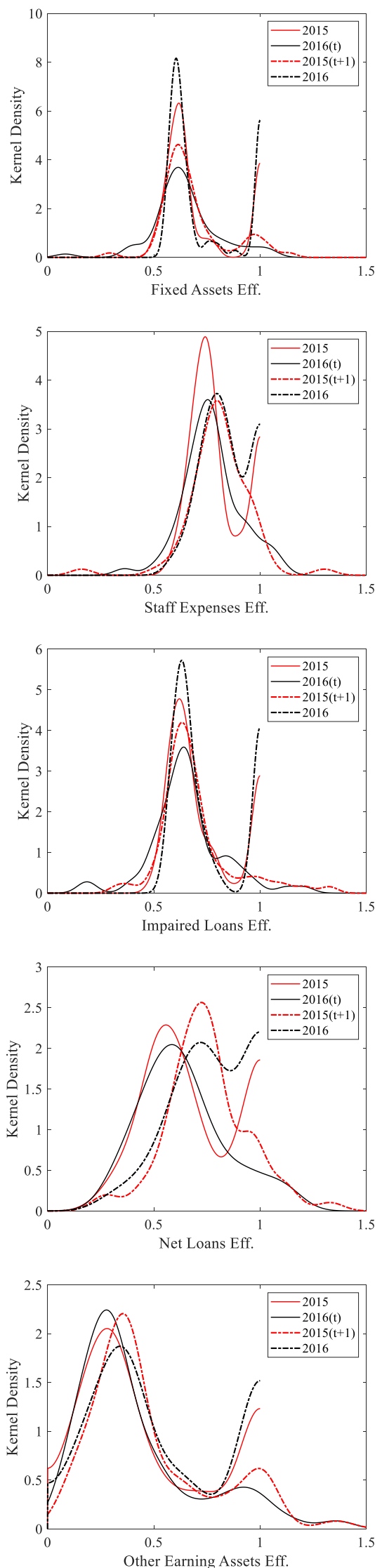
Figure S14. Convergence in efficiency for the period 2015-2016

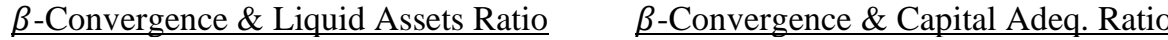
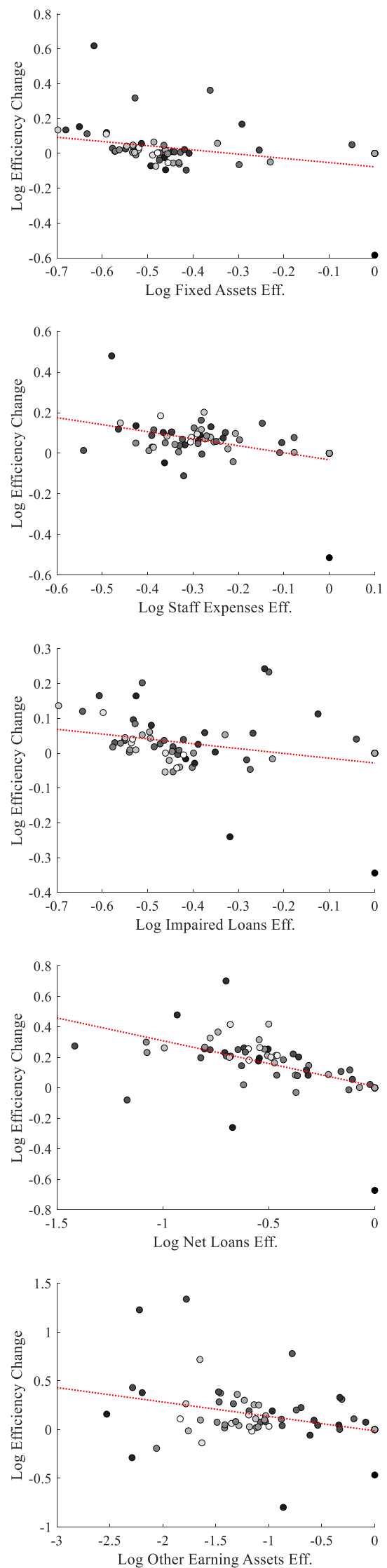
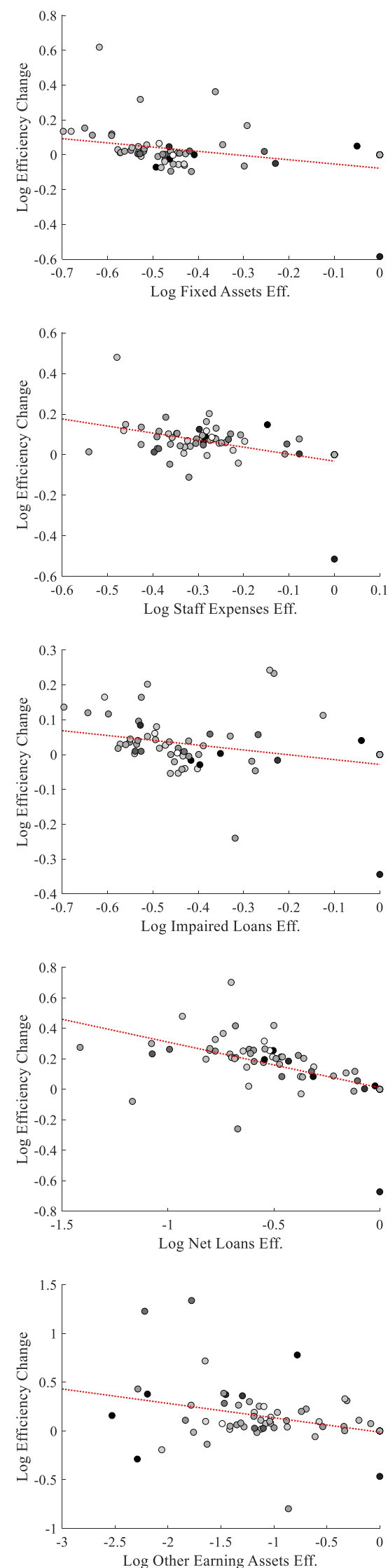

$\underline{\text { Kernel Densities }}$
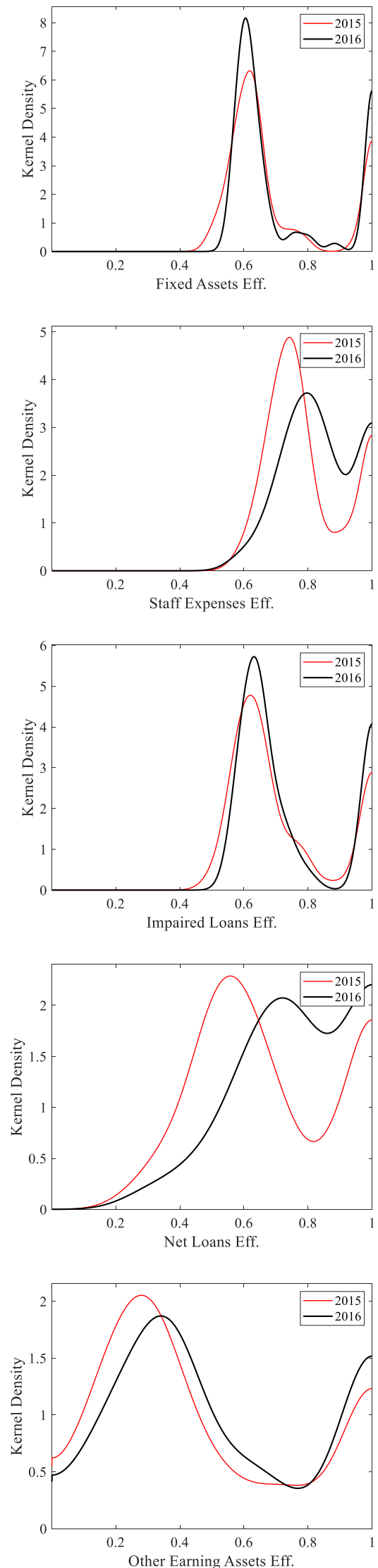
Figure S15. Convergence in technology for the period 2015-2016

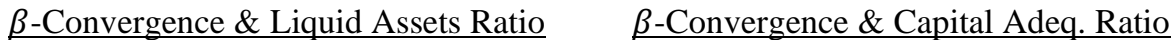
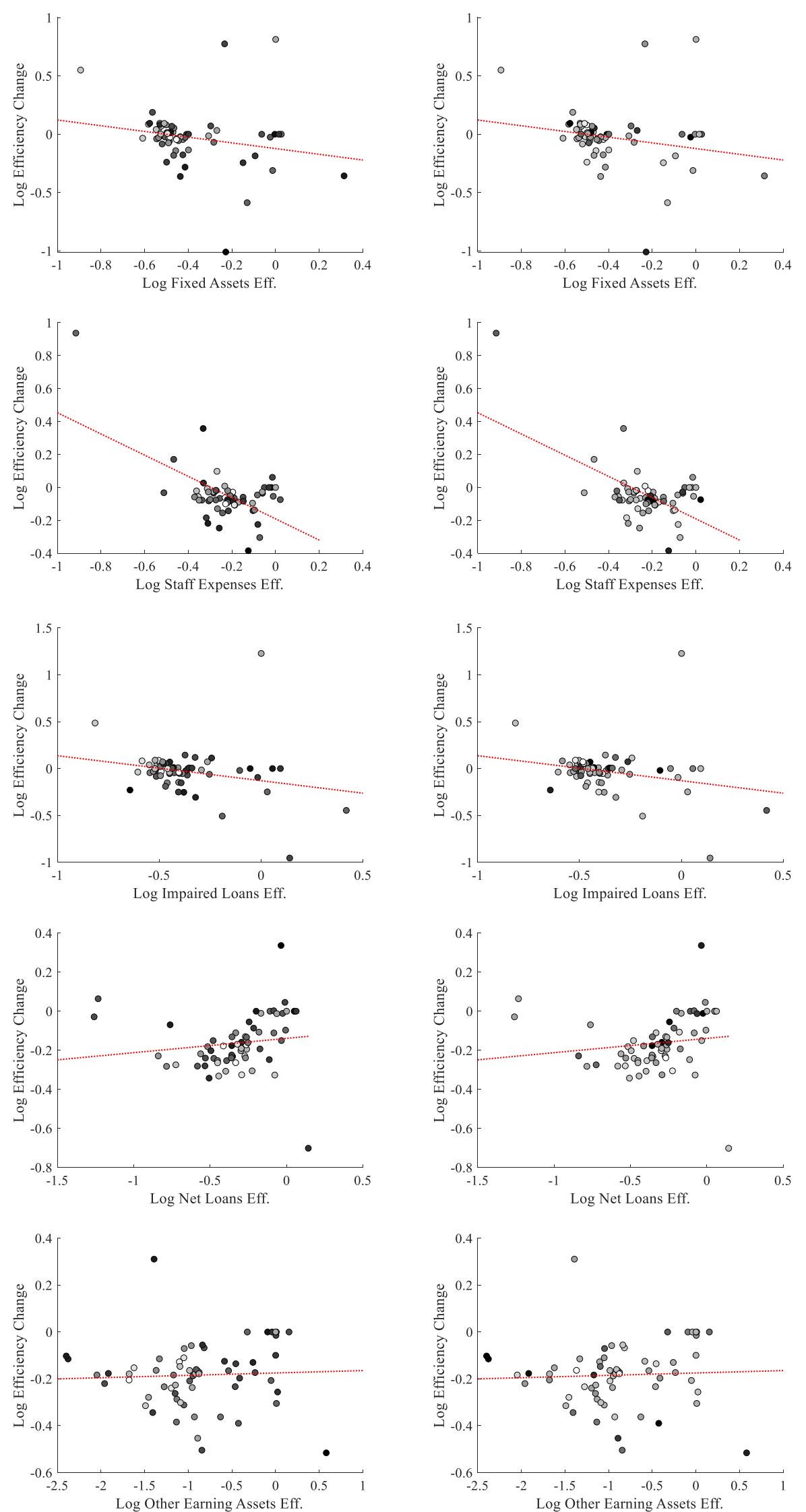
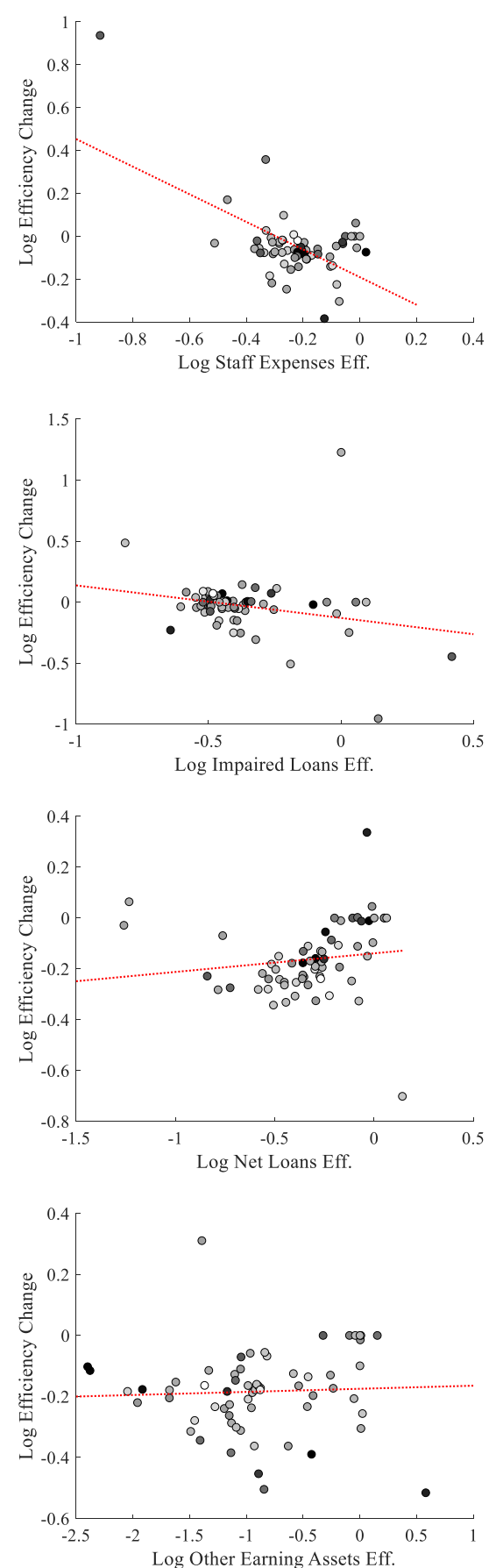

$\underline{\text { Kernel Densities }}$
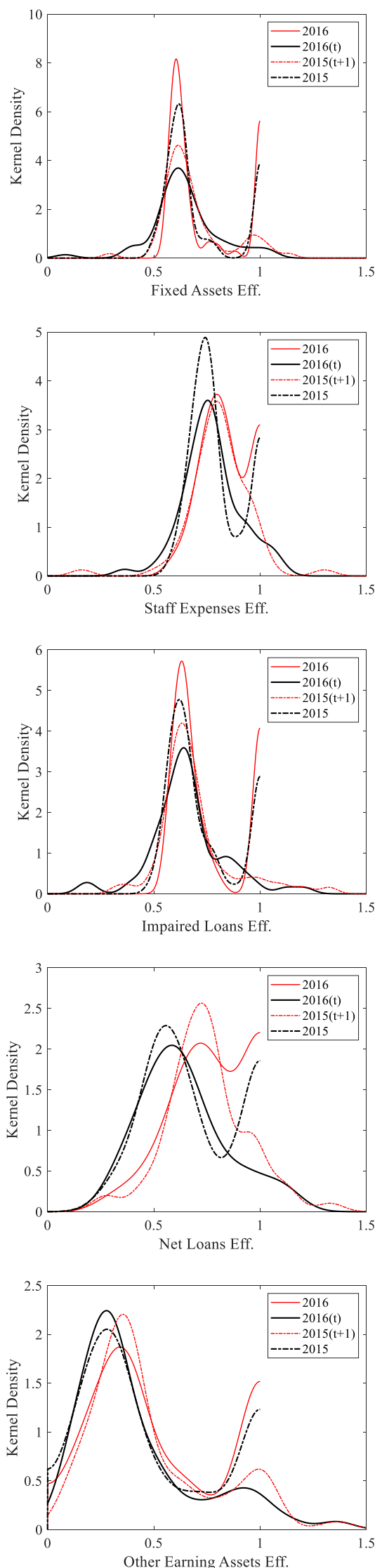
Figure S16. Convergence in productivity for the period 2016-2017

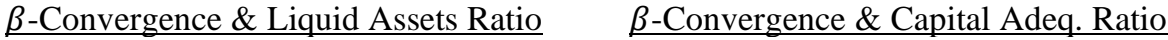
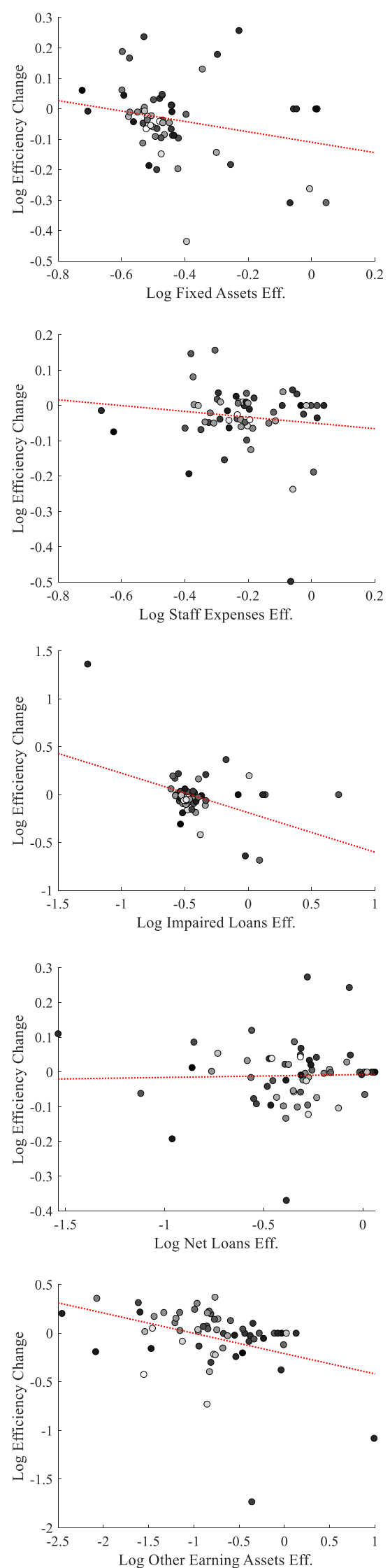
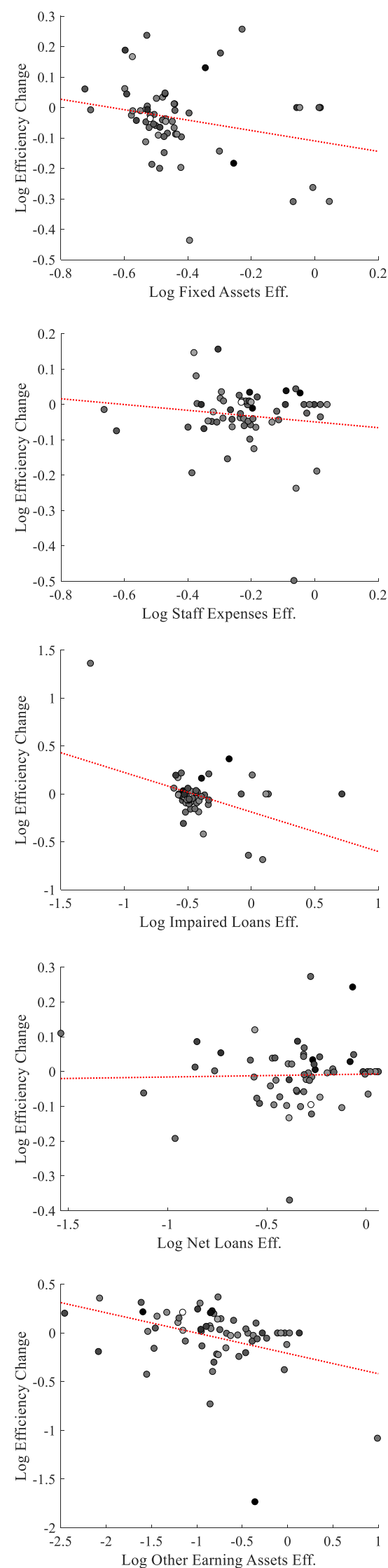

$\underline{\text { Kernel Densities }}$
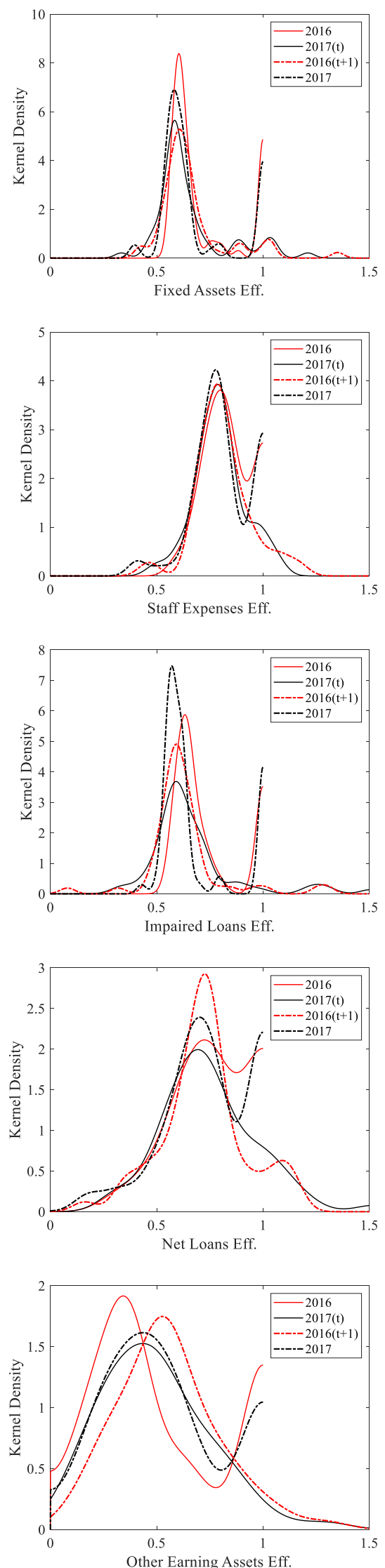
Figure S17. Convergence in efficiency for the period 2016-2017

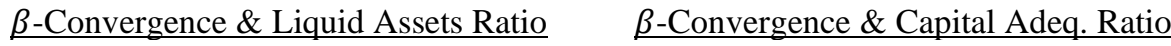
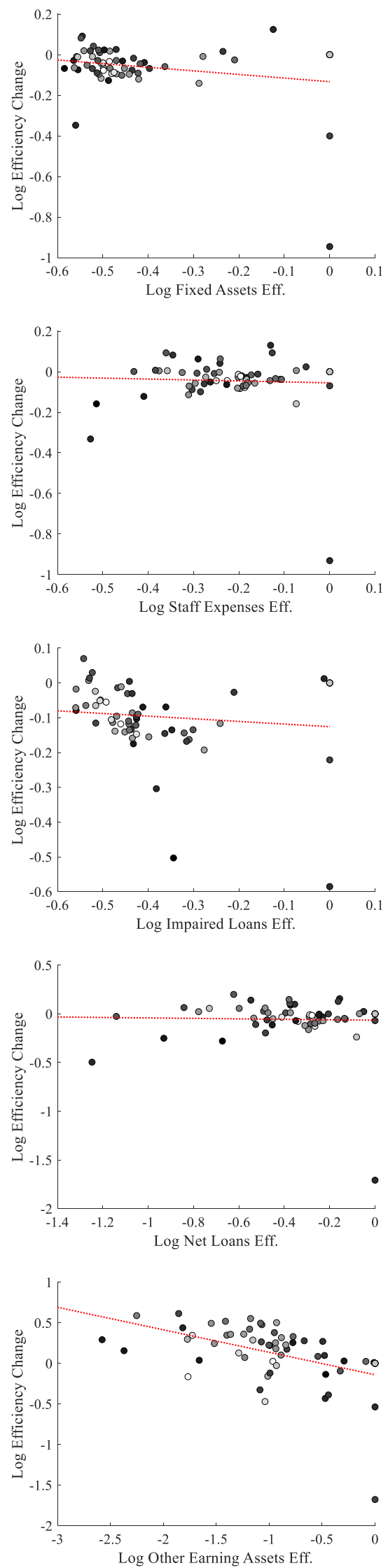
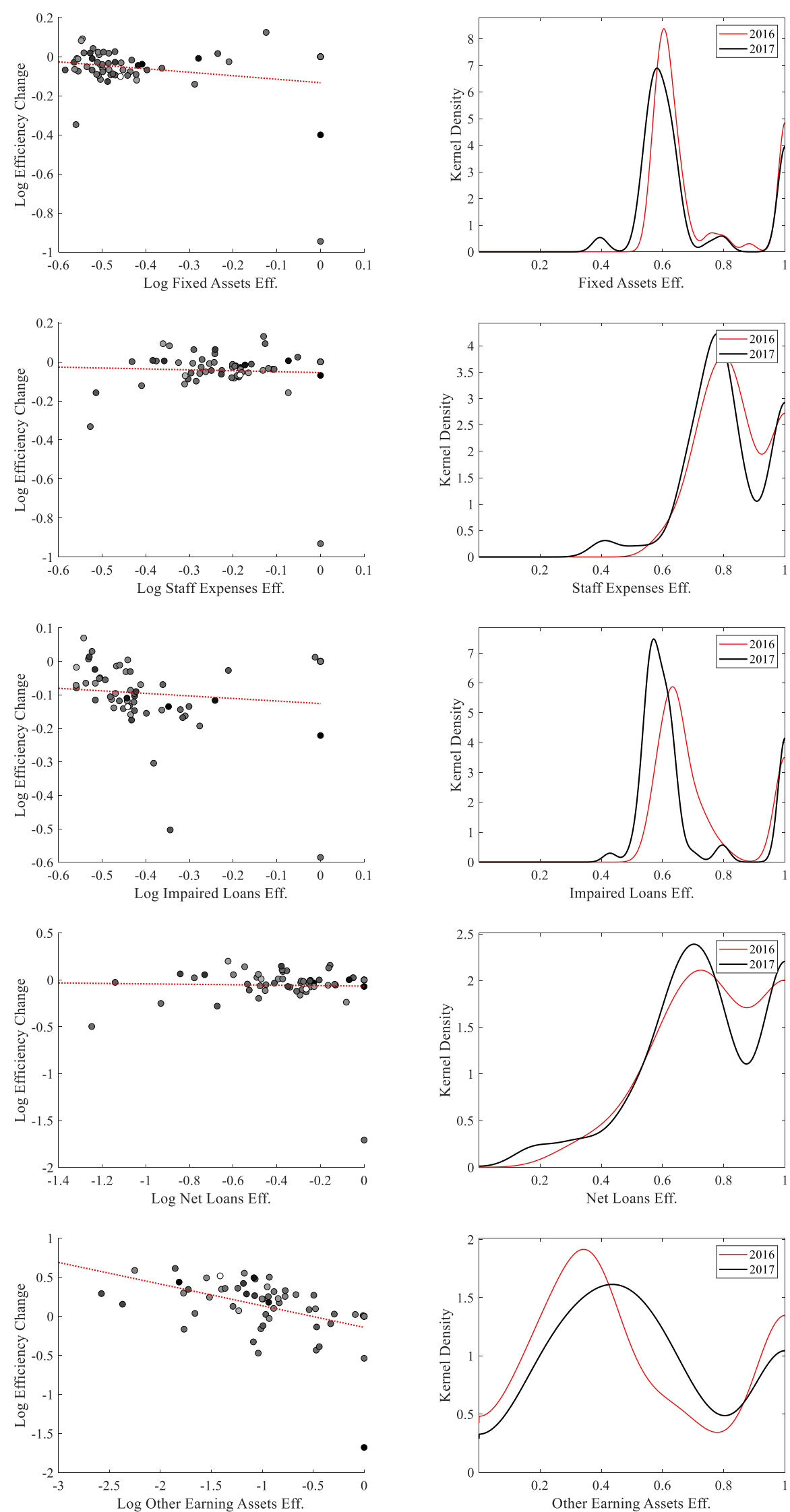
Figure S18. Convergence in technology for the period 2016-2017

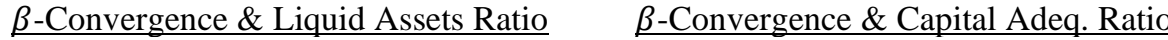
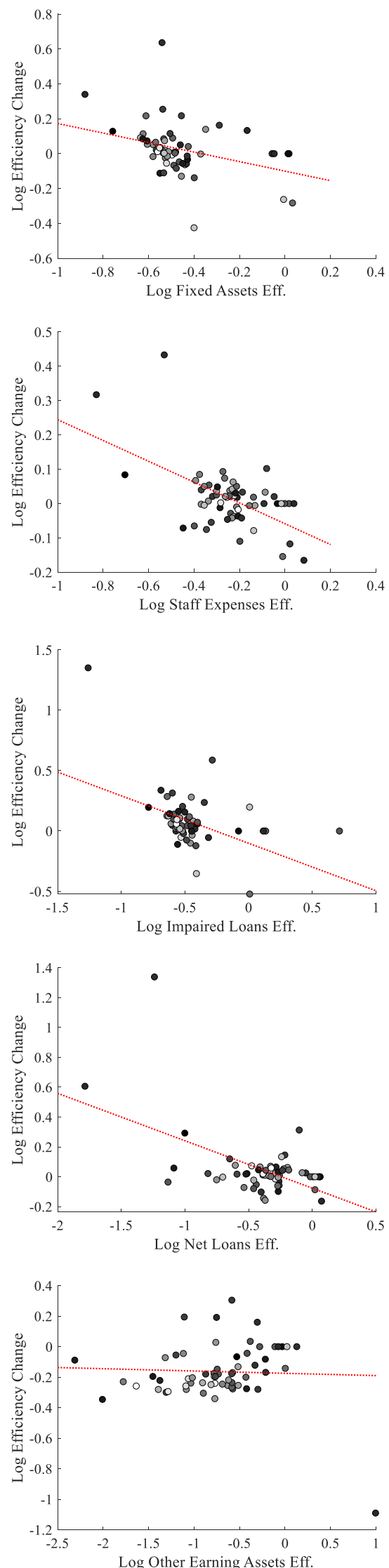
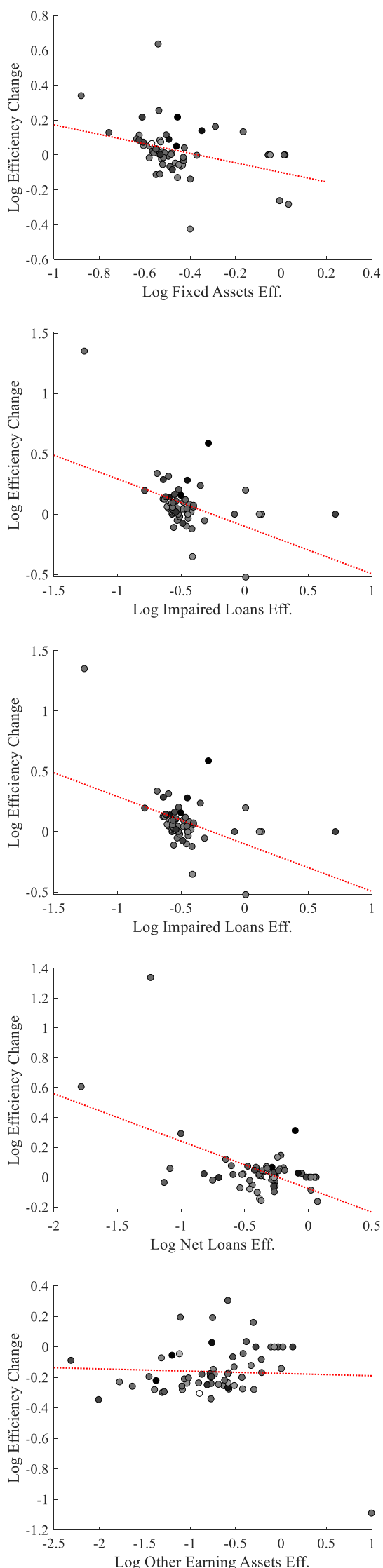
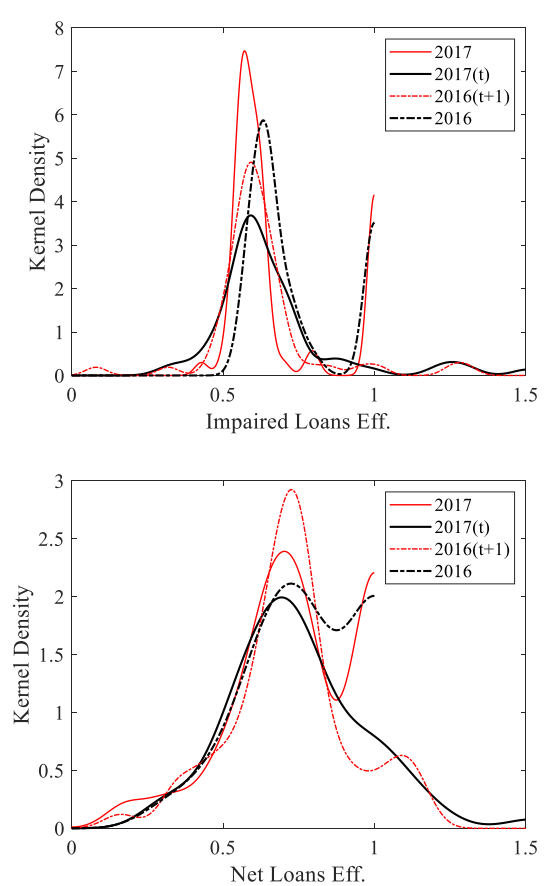

$\underline{\text { Kernel Densities }}$
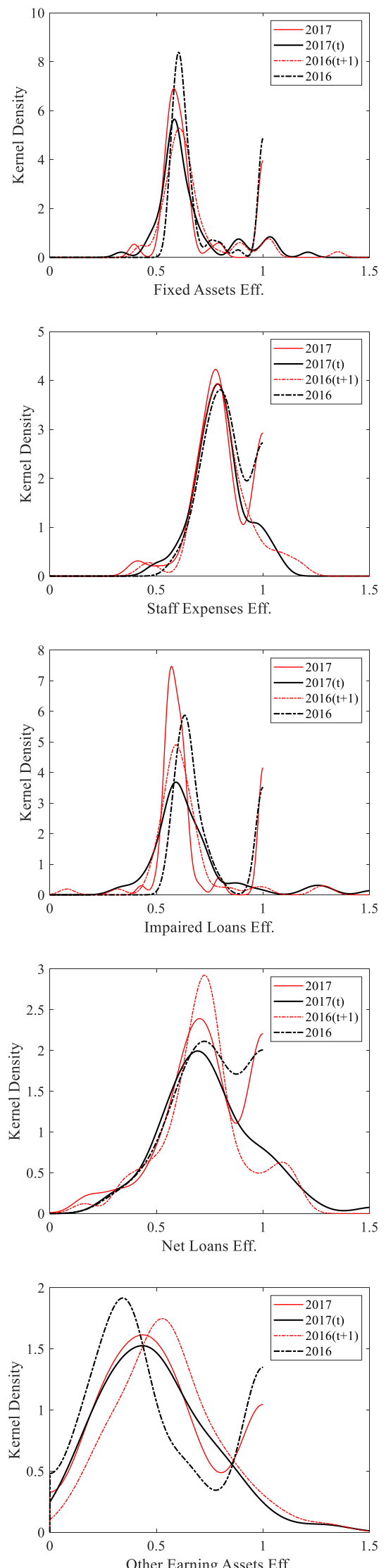
Table S7. Convergence results for the period 2011-2012

\begin{tabular}{|c|c|c|c|c|c|c|c|c|c|}
\hline \multirow{3}{*}{ Fixed Assets } & \multicolumn{3}{|c|}{$\underline{\text { Convergence in Productivity }}$} & \multicolumn{3}{|c|}{$\underline{\text { Convergence in Efficiency }}$} & \multicolumn{3}{|c|}{$\underline{\text { Convergence in Technology }}$} \\
\hline & $\beta_{0}$ & $\beta_{1}$ & & $\beta_{0}$ & $\beta_{1}$ & & $\beta_{0}$ & $\beta_{1}$ & \\
\hline & $-0.120 * * *$ & $-0.248 * * *$ & & 0.008 & -0.046 & & $-0.135 * * *$ & $-0.225 * * *$ & \\
\hline Staff Expenses & $-0.183^{* * *}$ & $-0.520 * * *$ & & 0.003 & -0.044 & & $-0.191 * * *$ & $-0.505 * * *$ & \\
\hline NPLs & $-0.290 * * *$ & $-0.618 * * *$ & & -0.016 & $-0.118 * *$ & & $-0.316^{* * *}$ & $-0.616^{* * *}$ & \\
\hline Net Loans & -0.001 & 0.006 & & 0.024 & 0.056 & & -0.055 & -0.098 & \\
\hline Other Earn. Assets & $-0.111^{*}$ & $-0.109 * *$ & & 0.018 & $-0.107 * * *$ & & $-0.166^{* * *}$ & -0.027 & \\
\hline Liquid Assets Ratio & $\beta_{0}$ & $\beta_{1}$ & $\beta_{2}$ & $\beta_{0}$ & $\beta_{1}$ & $\beta_{2}$ & $\beta_{0}$ & $\beta_{1}$ & $\beta_{2}$ \\
\hline Fixed Assets & -0.111 & $-0.245^{* * *}$ & -0.003 & -0.001 & -0.049 & 0.003 & -0.121 & $-0.219 * * *$ & -0.004 \\
\hline Staff Expenses & $-0.142^{* *}$ & $-0.507 * * *$ & -0.014 & -0.009 & -0.048 & 0.004 & $-0.140 * *$ & $-0.488 * * *$ & -0.018 \\
\hline NPLs & $-0.484 * * *$ & $-0.670 * * *$ & $0.065^{* *}$ & -0.042 & $-0.129 * *$ & 0.008 & $-0.526 * * *$ & $-0.671 * * *$ & $0.071 * *$ \\
\hline Net Loans & -0.154 & 0.017 & 0.060 & 0.042 & 0.055 & -0.007 & $-0.212 * *$ & -0.087 & $0.062 *$ \\
\hline Other Earn. Assets & -0.013 & $-0.096^{*}$ & -0.031 & $0.309 * *$ & -0.064 & $-0.089 * *$ & $-0.375^{* *}$ & -0.055 & 0.067 \\
\hline $\begin{array}{l}\text { Capital Adequacy } \\
\text { Ratio }\end{array}$ & $\beta_{0}$ & $\beta_{1}$ & $\beta_{2}$ & $\beta_{0}$ & $\beta_{1}$ & $\beta_{2}$ & $\beta_{0}$ & $\beta_{1}$ & $\beta_{2}$ \\
\hline Fixed Assets & $-0.116^{* *}$ & $-0.246^{* * * *}$ & 0.000 & 0.038 & -0.032 & -0.003 & $-0.159 * * *$ & $-0.234 * * *$ & 0.002 \\
\hline Staff Expenses & $-0.176^{* * *}$ & $-0.518 * * *$ & -0.001 & 0.026 & -0.035 & -0.002 & $-0.201 * * *$ & $-0.507 * * *$ & 0.001 \\
\hline NPLs & $-0.328 * * *$ & $-0.626^{* * *}$ & 0.004 & -0.006 & $-0.114^{*}$ & -0.001 & $-0.366^{* * *}$ & $-0.625 * * *$ & 0.005 \\
\hline Net Loans & 0.020 & 0.007 & -0.002 & 0.057 & 0.057 & -0.003 & -0.067 & -0.098 & 0.001 \\
\hline Other Earn. Assets & 0.055 & $-0.087 *$ & $-0.015 * *$ & $0.152 *$ & $-0.089 * *$ & $-0.012 * *$ & -0.138 & -0.024 & -0.003 \\
\hline
\end{tabular}

Table S8. Convergence results for the period 2012-2013

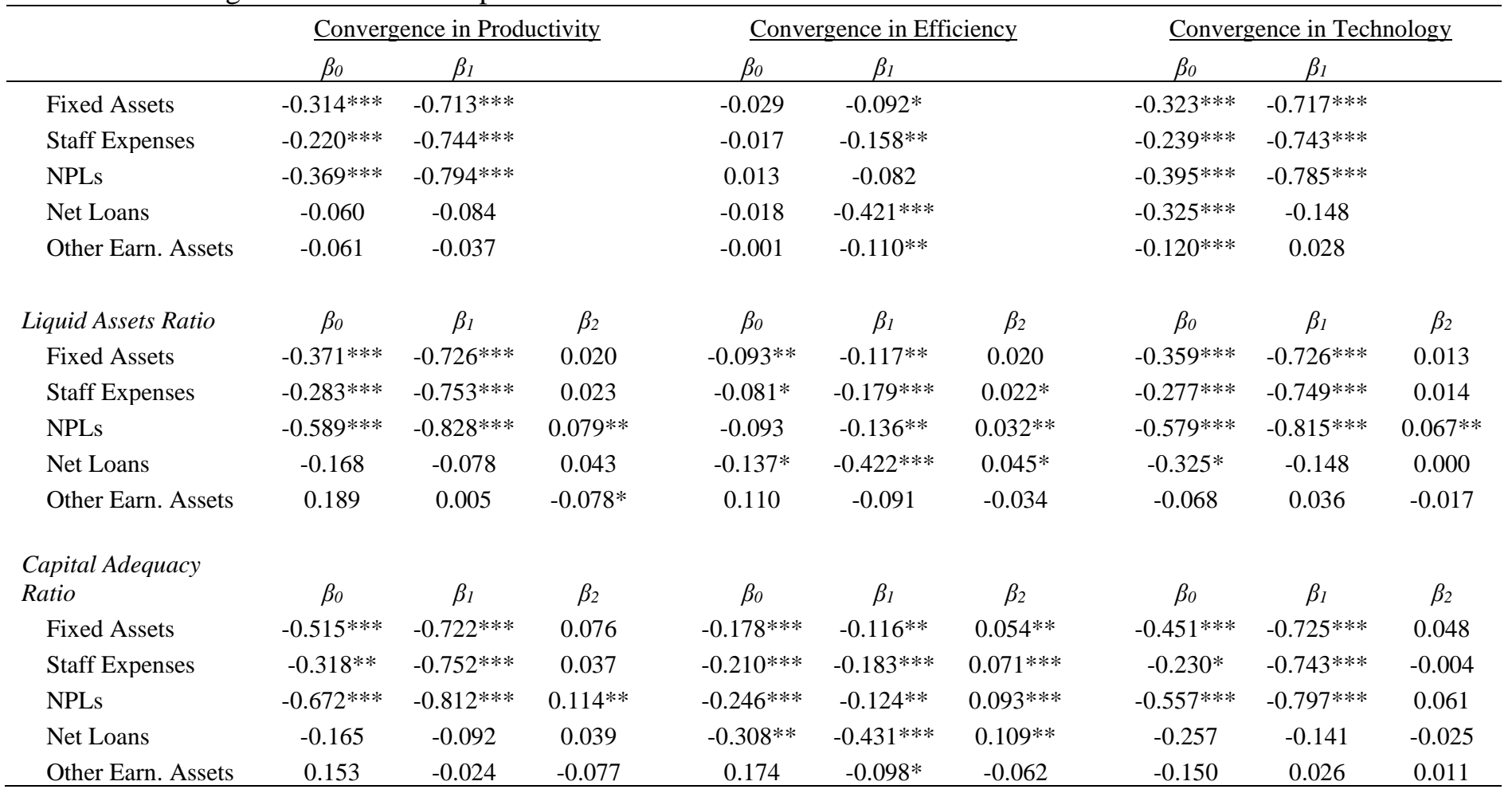


Table S9. Convergence results for the period 2013-2014

\begin{tabular}{|c|c|c|c|c|c|c|c|c|c|}
\hline $2013-2014$ & \multicolumn{3}{|c|}{ Convergence in Productivity } & \multicolumn{3}{|c|}{ Convergence in Efficiency } & \multicolumn{3}{|c|}{ Convergence in Technology } \\
\hline Staff Expenses & $-0.119 * * *$ & $-0.436 * * *$ & & $-0.037 * *$ & $-0.121 * *$ & & $-0.107 * * *$ & $-0.399 * * *$ & \\
\hline Net Loans & -0.055 & $-0.142 * *$ & & $-0.047 * *$ & 0.006 & & -0.035 & $-0.202 * * *$ & \\
\hline Other Earn. Assets & $-0.153^{*}$ & $-0.121 * *$ & & $-0.197 * *$ & -0.066 & & 0.009 & $-0.085^{* * *}$ & \\
\hline Staff Expenses & $-0.178 * *$ & $-0.460 * * *$ & 0.020 & 0.029 & $-0.088 *$ & $-0.022 * *$ & $-0.221 * * *$ & $-0.439 * * *$ & 0.039 \\
\hline NPLs & -0.326 & $-0.398 * *$ & 0.085 & -0.023 & -0.089 & -0.015 & -0.340 & $-0.369 *$ & 0.103 \\
\hline Net Loans & $-0.205 * * *$ & $-0.145^{* *}$ & $0.057 * *$ & -0.009 & 0.012 & -0.014 & $-0.217 * * *$ & $-0.203 * * *$ & $0.069 * * *$ \\
\hline Other Earn. Assets & -0.310 & $-0.141^{* *}$ & 0.051 & $-0.384 *$ & -0.094 & 0.060 & -0.012 & $-0.087 * * *$ & 0.007 \\
\hline Capital Adequacy & & & & & & & & & \\
\hline NPLs & $-1.178 * *$ & $-0.377 * *$ & $0.397 * *$ & $-0.211 *$ & $-0.138 * * *$ & 0.048 & $-1.091 * *$ & $-0.340^{*}$ & $0.379 *$ \\
\hline Net Loans & -0.296 & $-0.152 * *$ & 0.087 & -0.136 & 0.003 & 0.032 & -0.221 & $-0.211 * * *$ & 0.067 \\
\hline Other Earn. Assets & 0.426 & $-0.117 * *$ & -0.211 & 0.368 & -0.063 & -0.206 & 0.040 & $-0.085^{* * *}$ & -0.011 \\
\hline
\end{tabular}

Table S10. Convergence results for the period 2014-2015

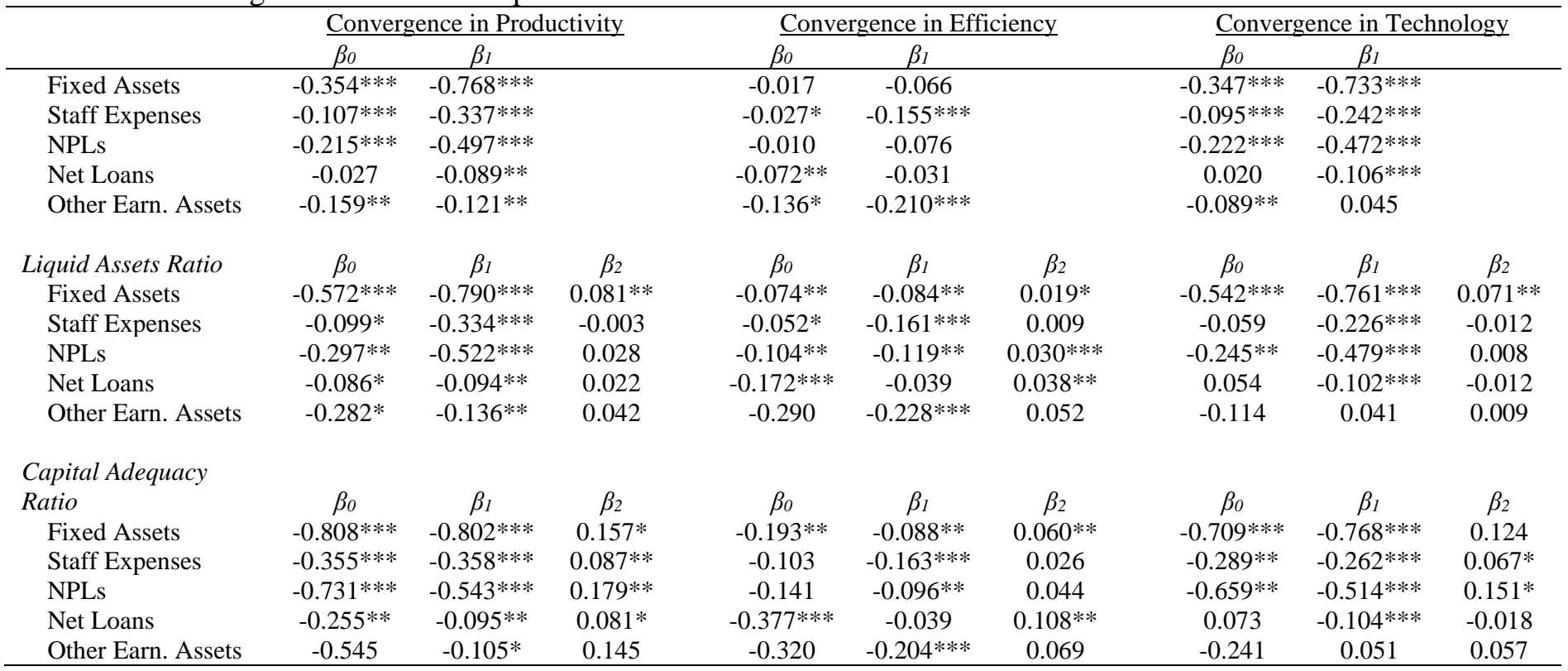


Table S11. Convergence results for the period 2015-2016

\begin{tabular}{|c|c|c|c|c|c|c|c|c|c|}
\hline \multirow{2}{*}{$2015-2016$} & \multicolumn{3}{|c|}{ Convergence in Productivity } & \multicolumn{3}{|c|}{ Convergence in Efficiency } & \multicolumn{3}{|c|}{ Convergence in Technology } \\
\hline & $\beta_{0}$ & $\beta_{1}$ & & $\overline{\beta_{0}}$ & $\beta_{1}$ & & $\overline{\beta_{0}}$ & $\beta_{1}$ & \\
\hline Fixed Assets & $-0.145^{*}$ & $-0.351 * *$ & & $-0.077^{*}$ & $-0.243 * * *$ & & $-0.123^{*}$ & -0.245 & \\
\hline Staff Expenses & $-0.185 * * *$ & $-0.783 * * *$ & & -0.032 & $-0.346 * * *$ & & $-0.191 * * *$ & $-0.644 * * *$ & \\
\hline NPLs & -0.109 & $-0.272 *$ & & -0.028 & $-0.139 * *$ & & $-0.129 * *$ & $-0.267 *$ & \\
\hline Net Loans & $-0.035^{*}$ & $-0.075 * *$ & & 0.010 & $-0.300 * * *$ & & $-0.139 * * *$ & 0.073 & \\
\hline Other Earn. Assets & $-0.138 * *$ & $-0.101 * *$ & & -0.013 & $-0.148 * *$ & & $-0.175^{* * *}$ & 0.010 & \\
\hline Liquid Assets Ratio & $\beta_{0}$ & $\beta_{1}$ & $\beta_{2}$ & $\beta_{0}$ & $\beta_{1}$ & $\beta_{2}$ & $\beta_{0}$ & $\beta_{1}$ & $\beta_{2}$ \\
\hline Fixed Assets & 0.124 & -0.227 & $-0.083 *$ & -0.129 & $-0.262 * * *$ & 0.016 & 0.176 & $-0.108 * * *$ & $-0.093 * * *$ \\
\hline Staff Expenses & -0.130 & $-0.769 * * *$ & -0.020 & 0.023 & $-0.327 * * *$ & -0.019 & $-0.181 * * *$ & $-0.643 * * *$ & $-0.004 * * *$ \\
\hline NPLs & 0.128 & -0.167 & $-0.075^{*}$ & -0.060 & $-0.155^{* *}$ & 0.010 & $0.083 *$ & $-0.177 * * *$ & $-0.068 * * *$ \\
\hline Net Loans & 0.012 & $-0.069 *$ & -0.017 & $0.173 * *$ & $-0.277 * * *$ & $-0.057 * *$ & $-0.287 * * *$ & $0.064^{*}$ & $0.055^{*}$ \\
\hline Other Earn. Assets & $-0.273^{*}$ & $-0.118 * *$ & 0.045 & -0.106 & $-0.159 * * *$ & 0.031 & $-0.249 * * *$ & $0.000 * * *$ & $0.025 * *$ \\
\hline Capital Adequacy & & & & & & & & & \\
\hline Ratio & $\beta_{0}$ & $\beta_{1}$ & $\beta_{2}$ & $\beta_{0}$ & $\beta_{1}$ & $\beta_{2}$ & $\beta_{0}$ & $\beta_{1}$ & $\beta_{2}$ \\
\hline Fixed Assets & 0.276 & -0.285 & -0.137 & 0.161 & $-0.197 * *$ & -0.077 & 0.006 & -0.230 & -0.043 \\
\hline Staff Expenses & -0.235 & $-0.789 * * *$ & 0.017 & 0.090 & $-0.320 * * *$ & -0.040 & $-0.362 * *$ & $-0.655 * * *$ & 0.059 \\
\hline NPLs & 0.108 & -0.250 & -0.073 & 0.110 & $-0.114 *$ & -0.045 & -0.092 & $-0.264 *$ & -0.013 \\
\hline Net Loans & -0.077 & $-0.079 * *$ & 0.014 & $0.371^{*}$ & $-0.267 * * *$ & $-0.120 *$ & $-0.689 * * *$ & 0.043 & $0.188 * * *$ \\
\hline Other Earn. Assets & -0.276 & $-0.098 *$ & 0.049 & -0.267 & $-0.141 * *$ & 0.091 & -0.009 & 0.007 & -0.059 \\
\hline
\end{tabular}

Table S12. Convergence results for the period 2016-2017

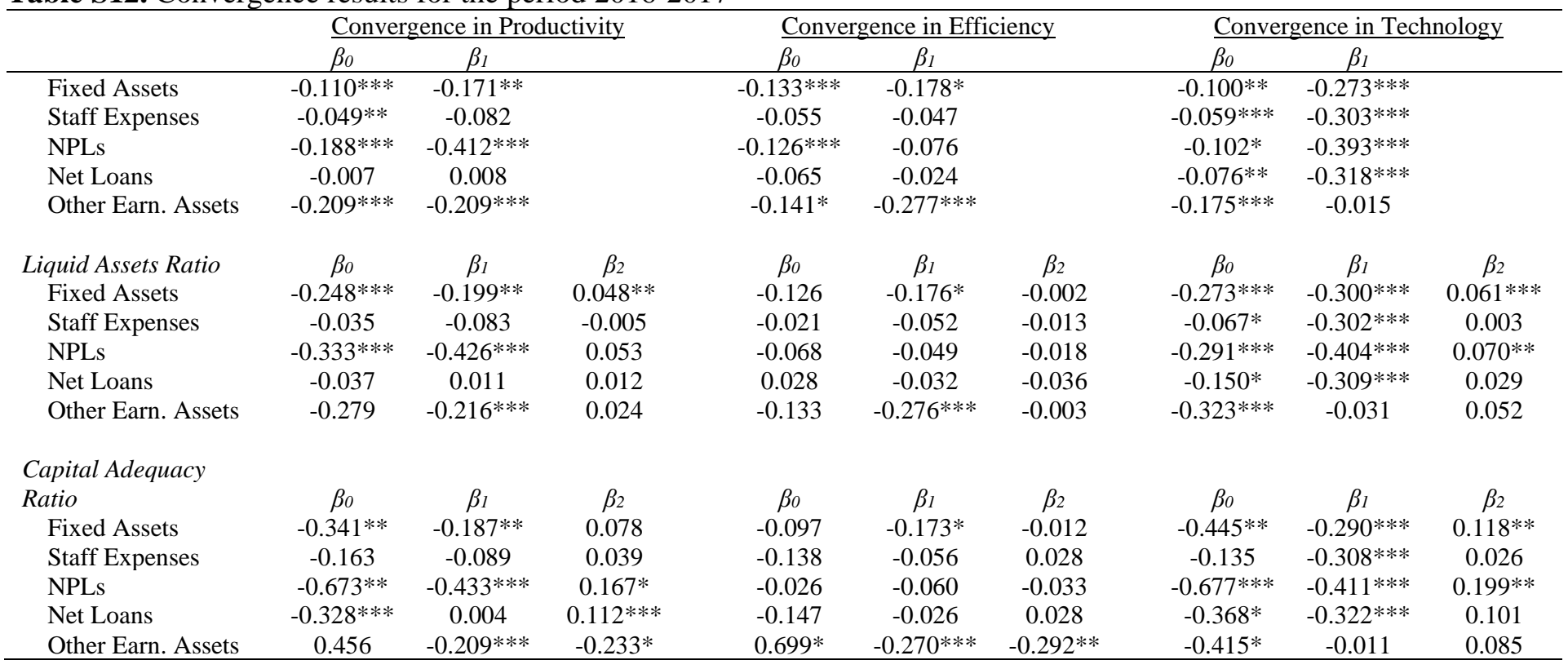

